\title{
PAULA FERNANDES
}

Imunorregulação induzida pelo exercício físico na inflamação pulmonar alérgica crônica

Dissertação apresentada à Faculdade de Medicina da Universidade de São Paulo para obtenção do título de Mestre em Ciências

Programa de Fisiopatologia Experimental

Orientadora: Dra. Fernanda Magalhães Arantes-Costa

São Paulo 


\section{PAULA FERNANDES}

Imunorregulação induzida pelo exercício físico na inflamação pulmonar alérgica crônica

Dissertação apresentada à Faculdade de Medicina da Universidade de São Paulo para obtenção do título de Mestre em Ciências

Programa de Fisiopatologia Experimental

Orientadora: Dra. Fernanda Magalhães Arantes-Costa

São Paulo 
Dados Internacionais de Catalogaçăo na Publicaçăo (CIP)

Preparada pela Biblioteca da

Faculdade de Medicina da Universidade de Săo Paulo

Creproduçăo autorizada pelo autor

Fernandes, Paula

Imunorregulaçăo induzida pelo exercício fisico na inflamaçăo pulmonar alérgica crônica / Paula Fernandes. -- Săo Paulo, 2019.

Dissertaçăo (mestrado)--Faculdade de Medicina da Universidade de São Paulo.

Programa de Fisiopatologia Experimental.

Orientadora: Fernanda Magalhäes Arantes Costa.

Descritores: 1.Alergia 2.Asma

3. Herpesensibilidade 4. Inflamaçäo 5. Imunologia

6. Exercicio 7. Imunorregulaçăo

$\mathrm{USP} / \mathrm{FM} / \mathrm{DBD}-006 / 19$

Responsável: Erinalva da Conceiçăo Batista, CRB-8 6755 
Dedico à minha família. 


\section{AGRADECIMENTOS}

Agradeço primeiramente a Deus, por me possibilitar concluir mais uma etapa tão sonhada em minha vida.

Agradeço aos meus pais Lourdes e Francisco e meu irmão Felipe, por acreditarem em meus sonhos e me apoiarem em todos os sentidos nas escolhas mais importantes da minha vida. Minha eterna gratidão, por cada momento.

Agradeço ao meu melhor amigo e companheiro, Luis, por estar presente nos momentos em que mais precisei durante os últimos anos.

Agradeço infinitamente a minha amiga, companheira, "mãezona" e também orientadora, Dra. Fernanda Arantes, por ter me acompanhado todos esses anos, desde a iniciação científica - quando eu não sabia absolutamente nada sobre asma, exercício e todo esse mundo que faz parte da minha vida hoje. Agradeço por toda a paciência, compreensão, generosidade, por ser essa professora maravilhosa que dá os melhores exemplos e faz as melhores analogias. Obrigada por me ensinar o que é ciência e como se faz ciência. Agradeço também pela amizade, confiança e companheirismo.

Agradeço a Luana, por ter ajudado nos experimentos e principalmente por ter me inserido no mundo da citometria de fluxo ou melhor dizendo, da imunologia.

Agradeço a Dra. Maria Sato, por ter permitido a colaboração com o LIM 56, que possibilitou a realização dos experimentos deste trabalho. 
Agradeço minha querida amiga Thayse, por ter ajudado nos experimentos e principalmente por ter tirado minhas dúvidas de "Flow Jo", mesmo que seja a distância.

Agradeço a grande amiga Bruni, por tirar tantas dúvidas a respeito de imunologia e também por todas as longas conversas a respeito da vida.

Agradeço a Rô, por sempre ajudar em tudo o que eu precisei e por ser essa grande amiga que sei que posso contar.

Agradeço ao querido amigo Davi, por ter se colocado sempre disponível para me ajudar com os animais e principalmente, pelas orações poderosas que sempre fez por mim.

Agradeço a Sara e a Fê Roncon por todos os experimentos que me auxiliaram e também pelas longas conversas.

Agradeço a querida amiga "Clarys", por auxiliar em todas as dúvidas a respeito de exercício físico e também por todos os desabafos do dia a dia.

Agradeço ao Prof. Dr. Milton e a Dr. Iolanda por terem me permitido fazer parte do laboratório.

Aos demais colegas e companheiros do LIM 20, muito obrigada por compartilhar todos esses anos.

À USP, pela oportunidade.

Muito Obrigada! 
“A esperança não decepciona."

$R m 5,5$. 


\section{NORMALIZAÇÃO ADOTADA}

Esta dissertação está de acordo com as seguintes normas, em vigor no momento desta publicação:

Referências: adaptado de International Committee of Medical Journals Editors (Vancouver).

Universidade de São Paulo. Faculdade de Medicina. Divisão de Biblioteca e Documentação. Guia de apresentação de dissertações, teses e monografias. Elaborado por Anneliese Carneiro da Cunha, Maria Julia de A. L. Freddi, Maria F. Crestana, Marinalva de Souza Aragão, Suely Campos Cardoso, Valéria Vilhena. 3a ed. São Paulo: Divisão de Biblioteca e Documentação; 2011.

Abreviaturas dos títulos dos periódicos de acordo com List of Journals Indexed in Index Medicus. 


\section{SUMÁRIO}

\section{Lista de Figuras}

\section{Lista de Abreviaturas}

\section{Resumo}

\section{Abstract}

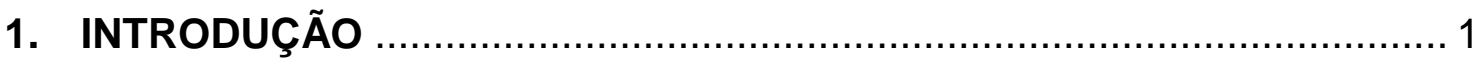

1.1 Asma - Definição e Epidemiologia............................................... 1

1.2 Fisiopatologia da Asma .......................................................... 2

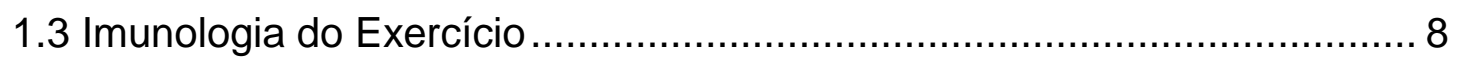

1.4 Asma e Exercício ................................................................. 10

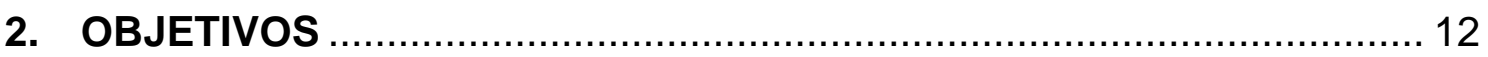

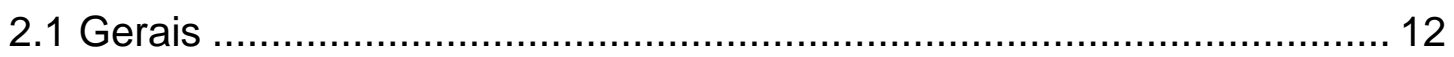

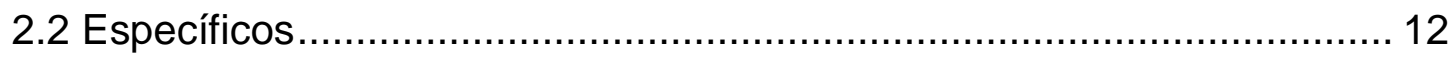

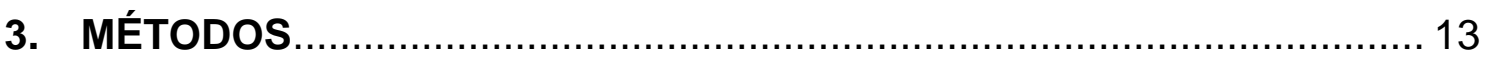

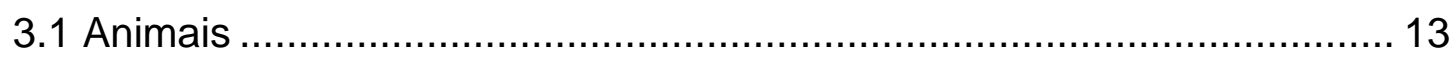

3.2 Indução da Inflamação Alérgica Pulmonar........................................ 13

3.3 Teste físico e treinamento aeróbico ............................................... 14

2.4 Grupos Experimentais.................................................................. 16

2.5 Avaliação da Mecânica Pulmonar ................................................ 16

3.6 Coleta de Sangue para quantificação de Imunoglobulinas .................... 17

3.7 Homogenato do tecido pulmonar e análise histológica ......................... 18

3.8 Dosagem de citocinas por ELISA .............................................. 19

3.9 Desagregação do tecido pulmonar e linfoide ................................... 19 


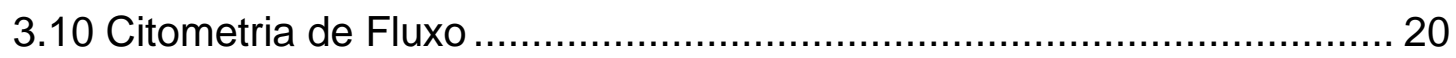

3.11 Dosagem de IgG1 e IgG2a por ELISA ……...................................... 22

3.12 Dosagem de lgE por reação de anafilaxia cutânea passiva ( $P C A-$ Passive cutaneous anaphylaxis) ........................................................... 23

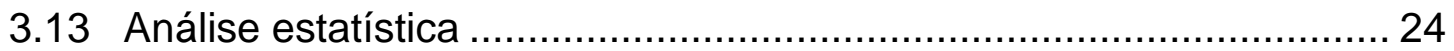

4. RESULTADOS

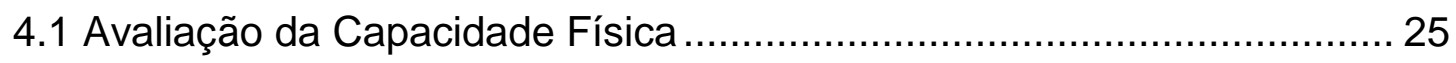

4.2 Avaliação da Responsividade Pulmonar............................................... 26

4.3 Avaliação de Células Epiteliais e de Quantificação de Mucosubstâncias

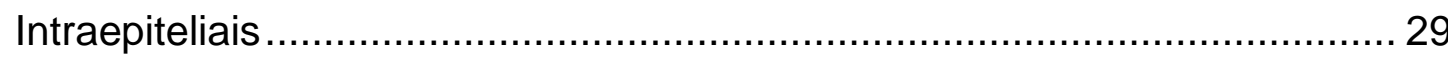

4.4 Dosagem de Anticorpos IgG1 e IgG2a anti-OVA .................................... 31

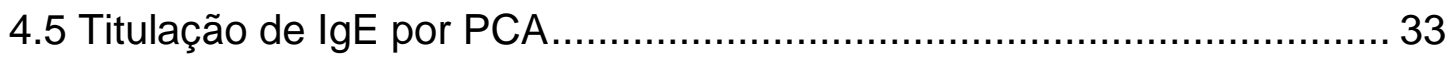

4.7 Avaliação Fenotípica das Células Inflamatórias Presentes no Tecido

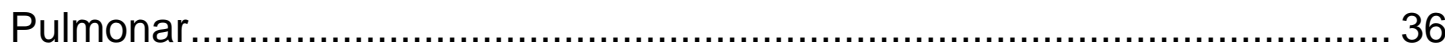

4.8 Avaliação Fenotípica das Células Inflamátórias Presentes no Tecido Linfóide

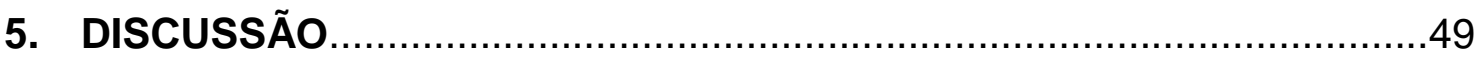

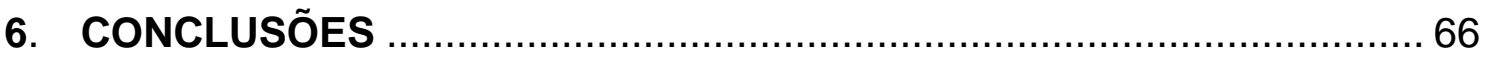

ANEXO

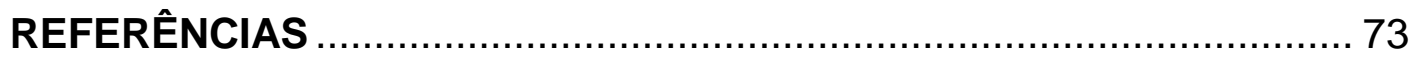




\section{LISTA DE FIGURAS}

Figura 1 - Esquema do protocolo experimental.

Figura 2 - O condicionamento físico dos animais treinados também pode ser observado ao se avaliar o tempo de treinamento.

Figura 3 - Curvas dose-resposta à metacolina mostrando os valores de elastância do sistema respiratório (Ers) obtidos após a inalação de concentrações crescentes de metacolina (Mch).

Figura 4 - Curvas dose-resposta à metacolina mostrando os valores de resistência do sistema respiratório (Rrs) obtidos após a inalação de concentrações crescentes de metacolina (Mch).

Figura 5 - Animais sensibilizados a ovalbumina apresentam hiperresponsividade quando avaliada a área sob as curvas de elastância do sistema respiratório e a presença da atividade física tende a reduzir essa elevação.

Figura 6 - Sensibilização ou exercícios físicos não alteram a responsividade proximal.

Figura 7 - A prática de exercício físico reduz a hiperplasia/hipertrofia epitelial gerada pela exposição ao antígeno OVA.

Figura 8 - A exposição ao antígeno aumenta produção de mucosubstâncias intraepiteliais e a atividade física reduz essa condição.

Figura 9 - A exposição antigênica associada à prática de exercício físico mantém elevado os níveis de IgG2a.

Figura 10 - A exposição antigênica associada à prática de exercício físico mantém elevado os níveis de IgG1.

Figura 11 - A prática de exercício físico moderado mantém elevada a produção de IgE anti-OVA.

Figura 12 - Quantificação de citocinas presentes no tecido pulmonar. 
Figura 13 - Exercício físico protege o pulmão da intensa eosinofilia induzida pela sensibilização a OVA.

Figura 14 - O exercício físico eleva o influxo de linfócitos CD4+ no pulmão de animais sensibilizados.

Figura 15 - O exercício físico induz intensa ativação dos linfócitos CD4+ pulmonares de animais alérgicos.

Figura 16 - O exercício físico eleva o influxo pulmonar de linfócitos T CD8+ em animais alérgicos.

Figura 17 - O exercício físico eleva a ativação nos linfócitos T CD8+ pulmonares em animais alérgicos.

Figura 18 - O exercício físico regula a inflamação induzida pela OVA com maior influxo pulmonar de Treg.

Figura 19 - O exercício físico induz maior produção de TGF- $\beta$ em Tregs pulmonares de animais alérgicos.

Figura 20 - O exercício físico amplifica a produção de IL-10 em Tregs pulmonares de animais alérgicos.

Figura 21 - O exercício exacerba o influxo de macrófagos pulmonares em animais alérgicos.

Figura 22 - Comportamento semelhante pode ser observado nos macrófagos pulmonares M2 de animais alérgicos praticantes de exercício físico.

Figura 23 - O exercício físico eleva o número de macrófagos pulmonares M1 de animais alérgicos.

Figura 24 - A sensibilização a ovalbumina associada ao treinamento físico não altera níveis de cDCs.

Figura 25 - O exercício físico e a sensibilização a ovalbumina elevam o número de células dendríticas plasmocitóides (pDCs) sem haver sinergia entre ambos os fatores.

Figura 26 - O exercício físico não altera o elevado número de linfócitos T CD4+ presentes nos linfonodos drenantes. 
Figura 27 - O exercício físico eleva a ativação dos linfócitos T CD4+ presentes nos linfonodos drenantes.

Figura 28 - O exercício físico não altera a liberação de TGF- $\beta$ nos linfócitos T CD4+ presentes nos linfonodos drenantes.

Figura 29 - O exercício físico não altera o número de linfócitos T CD8+ presentes nos linfonodos drenantes.

Figura 30 - O exercício físico também não altera a ativação dos linfócitos T CD8+ presentes nos linfonodos drenantes.

Figura 31 - O exercício físico não altera a liberação de TGF- $\beta$ nos linfócitos T CD8+ presentes nos linfonodos drenantes.

Figura 32 - O exercício físico não altera o número de Tregs presentes nos linfonodos drenantes.

Figura 33 - O exercício físico não altera a produção de IL-10 nos Tregs presentes nos linfonodos drenantes.

Figura 34 - O exercício físico reduz a migração de macrófagos M2 aos linfonodos drenantes em animais alérgicos.

Figura 35 - O exercício físico não altera a migração de macrófagos M1 aos linfonodos drenantes.

Figura 36 - O exercício físico reduz a ativação induzida pela OVA em cDCs no tecido linfoide.

Figura 37 - Quantificação de pDCs no tecido linfoide.

Figura 38 - Interação celular no pulmão e linfonodos de animais asmáticos e submetidos ao protocolo de treinamento. 


\section{LISTA DE ABREVIATURAS}

CD - Grupo de diferenciação (do inglês, Cluster Diferentiation)

cDC - Célula Dendritica Convencional (do inglês, Conventional Dendritic Cell)

CCL11- Eotaxina 1

CCL24 - do inglês, Chemokine ligand 24

CCL26 - do inglês, Chemokine ligand 26

Ers - Elastância do Sistema Respiratório

IgG1 - Imunoglobulina G1

IgG2a- Imunoglobulina G2a

$\lg \mathrm{E}$ - Imunoglobulina $\mathrm{E}$

IL - Interleucina

ILC2 - Células Linfoides inatas do grupo 2 (do inglês, group 2 innate lymphoid cells)

LIM 20 - Laboratório de Terapêutica Experimental 20

M1 - Macrófago do tipo 1 (macrófago inflamatório)

M2 - Macrófago do tipo 2 (macrófago alveolar)

MHC II - Complexo de Histocompatibilidade classe II (do inglês, major

histocompatibility complex class II)

OVA - Ovalbumina

PAS-AB - Coloração ácido periódico-Schiff azul (do inglês, periodic acid Shiffalcian blue)

PCA - do inglês, Passive Cutaneous Anaphylaxis

pDC - Célula Dendrítica Plasmocitóide (do inglês Plasmocitoid Dendritic Cell) 
Rrs - Resistência do Sistema Respiratório

TCD4+ - Linfócito T CD4+

TCD8+ - Linfócito T CD8+

TGF- $\beta$ - do inglês, Transforming Growth Factor $\beta$

Th - Linfócito T auxiliar ou (do inglês, T helper)

TNF- $\alpha$ - Fator de Necrose Tumoral (do inglês, Tumor Necrosis Factor $\alpha$ )

T reg - Célula T reguladora

TSLP - do inglês, Thymic Stromal Lymplopoitin 


\section{RESUMO}

Fernandes P. Imunorregulação induzida por exercício físico na inflamação pulmonar alérgica crônica [dissertação]. São Paulo: Faculdade de Medicina, Universidade de São Paulo; 2018.

Os benefícios do exercício físico moderado na asma alérgica são bem conhecidos, indicando que o exercício físico tem efeito anti-inflamatório reduzindo as respostas de Th2 e remodelamento pulmonar, porém os mecanismos dessa imunorregulação ainda não são bem descritos. Esse estudo é proposto com o objetivo de investigar os mecanismos de imunorregulação induzidos pelo exercício físico moderado sobre a inflamação da asma experimental. Camundongos Balb/c foram sensibilizados com ovalbumina (OVA) e alúmen nos dias $0,14,21,28$ e 42 e desafiados com aerossol de OVA três vezes por semana, desde o dia 21 até o dia 51 (grupos OVA e OVA + exercício (OEX). Um teste de capacidade máxima foi realizado nos dias 21 e 51 . Os grupos EX (exercício) e OEX praticaram exercício moderado nos dias 21 até 51 . Vinte e quatro horas após o último desafio, os animais ( $n=8 /$ grupo) foram anestesiados, traqueostomizados e ventilados mecanicamente, para avaliação da responsividade pulmonar. Foi realizada a coleta de sangue dos animais através da veia cava inferior para análise de imunoglobulinas e os animais foram posteriormente eutanasiados. Os pulmões foram então, removidos para quantificação de citocinas no homogenato e processamento histológico. Em outros grupos de animais ( $n=8 /$ grupo), avaliamos as células inflamatórias no pulmão e nos linfonodos mediastinais por citometria de fluxo. A avaliação da capacidade física comprovou maior condicionamento físico nos animais submetidos ao protocolo de treinamento. Animais sensibilizados a ovalbumina apresentam hiperresponsividade e a presença da atividade física reduziu essa elevação. A prática de exercício físico reduz a hiperplasia/hipertrofia epitelial e produção de mucosubstânicas intraepiteliais gerada pela exposição a OVA. A exposição antigênica eleva os níveis de $\lg G 2 a, \lg G 1$ e $\lg$ e o oxercício físico 
não modificou essa condição. A sensibilização eleva os níveis de IL-4, IL-6, o exercício físico apresenta capacidade de diminuir a quantidade dessas citocinas, já com as citocinas IL-10 e TGF- $\beta$ há o aumento dos níveis nos grupos treinados. $\mathrm{Na}$ análise do perfil celular, foi observado que o exercício físico protege o pulmão da intensa eosinofilia induzida pela sensibilização a OVA com intenso influxo pulmonar de Treg nos animais OEX, com maior produção de IL-10 e TGF- $\beta$. O exercício em animais sensibilizados também elevou o influxo de macrófagos pulmonares, M1 e M2 bem como influxo e ativação de linfócitos TCD4+ e TCD8+. Nos linfonodos drenantes, foi observado também que o exercício físico por si só eleva a ativação dos linfócitos TCD4+, independentemente da presença de OVA, enquanto que nos animais sensibilizados há redução da migração de macrófagos M2. Na análise de células dendríticas, foi observado em linfonodos dos grupos submetidos ao protocolo de treinamento e sensibilizados há redução da expressão de moléculas CD80, CD86 e ICOSL em cDCs, e aumento de ICOSL pDCs, sendo que nestas mesmas células há redução de CD80. O exercício físico, ao induzir maior influxo local de células regulatórias modula a inflamação pulmonar reduzindo o influxo eosinofílico pulmonar, a responsividade pulmonar, bem como o remodelamento epitelial e produção de muco induzido pelo antígeno ovalbumina.

Descritores: alergia; asma; hipersensibilidade; inflamação; imunologia; exercício; imunorregulação. 


\section{ABSTRACT}

Fernandes P. Immunoregulation induced by physical exercise in chronic allergic pulmonary inflammation [dissertation]. São Paulo: "Faculdade de Medicina, Universidade de São Paulo"; 2018

The benefits of moderate physical exercise in allergic asthma are well known, indicating that physical exercise has an anti-inflammatory effect reducing Th2 responses and pulmonary remodeling, but the mechanisms of this immunoregulation are not yet well described. This study aims to investigate the mechanisms of immunoregulation induced by moderate physical exercise on the inflammation of experimental asthma. Balb/c mice were sensitized with ovalbumin (OVA) and alum on days $0,14,21,28$ and 42 and challenged with OVA aerosol three times a week from day 21 to day 51 (OVA and OVA + exercise groups (OEX) A maximal capacity test was performed on days 21 and 51. EX (exercise) and OEX groups performed moderate exercise on days 21 to 51 . Twenty-four hours after the last challenge, animals ( $n=8 /$ group) were anesthetized, tracheostomized and mechanically ventilated, to evaluate pulmonary responsiveness, blood was collected from the animals through the inferior vena cava for immunoglobulin analysis, and the animals were later euthanized, and the lungs were then removed for quantification of cytokines ( $n=8 /$ group), we evaluated the inflammatory cells in the lung and in the mediastinal lymph nodes by flow cytometry. Analysis of the physical capacity demonstrated greater physical fitness in the animals submitted to the training protocol. Animals sensitized to ovalbumin presented hyperresponsiveness and the presence of physical activity reduced this elevation. The practice of physical exercise reduces epithelial hyperplasia/hypertrophy and intraepithelial mucosubstance production generated by OVA exposure. Antigenic exposure increases IgG2a, IgG1 and IgE levels and physical exercise did not modify this condition. Sensitization increases the levels of IL-4, IL-6, physical exercise has the capacity to decrease the amount of these cytokines and IL-10 and TGF- $\beta$ 
cytokines had an increase in levels in the trained groups. In the analysis of the cellular profile, it was observed that physical exercise protects the lung from intense eosinophilia induced by OVA sensitization with intense pulmonary influx of Treg in OEX animals, with higher production of IL-10 and TGF- $\beta$. Exercise in sensitized animals also increased the influx of pulmonary macrophages, M1 and M2 as well as influx and activation of TCD4+ and TCD8+ lymphocytes. In the draining lymph nodes, it was also observed that physical exercise alone increases the activation of CD4+ T lymphocytes, independently of the presence of OVA, whereas in the sensitized animals there was a reduction in M2 macrophages migration. In the analysis of dendritic cells, it was observed in lymph nodes of the groups submitted to the training protocol and sensitized there was a reduced expression of CD80, CD86 and ICOSL molecules in CDCs, and an increase of ICOSL pDCs, and in these same cells there is reduction of CD80. Physical exercise, by inducing greater local influx of regulatory cells, modulates pulmonary inflammation by reducing pulmonary eosinophil influx, pulmonary responsiveness, as well as epithelial remodeling and mucus production induced by the ovalbumin antigen.

Descriptors: allergy; asthma; hypersensitivity; inflammation; immunology; exercise; immunoregulation. 


\section{INTRODUÇÃO}

\subsection{Asma - Definição e Epidemiologia}

A asma é uma doença heterogênea, caracterizada pela inflamação crônica das vias aéreas e variável remodelamento (Reddel, Pedersen, 2018). É definida pelo histórico dos sintomas respiratórios, como chiado, respiração dificultada, aperto no peito e tosse, que varia de tempo e intensidade, juntamente com uma variável limitação do fluxo de ar (Kim, et al, 2013; Reddel, et al, 2015).

Sensibilidade a irritantes não específicos, agentes broncoconstritores e hiperresponsividades de vias aéreas são as características principais da asma (Barrett, Austen, 2009). É clinicamente classificada de acordo com a frequência dos sintomas, volume expiratório forçado em 1 segundo e pico de fluxo expiratório. Além disso, a asma pode ser classificada como leve, moderada ou grave, de acordo com a intensidade dos sintomas (GINA, 2018).

Em muitos pacientes, a doença pode ser controlada pela combinação de corticoesteróides inalados (que atuam suprimindo a inflamação) e agonista $\beta 2-$ adrenérgicos de longa ou curta duração (que atuam dilatando os brônquios pelo relaxamento da musculatura lisa), mas em alguns casos (5 a 10\% dos pacientes), a doença é refratária ao tratamento com corticoesteróide (Lambrecht, Hammad, 2015).

A doença é muito comum em sociedades afluentes, quase 1 em 10 crianças e 1 em 12 adultos são afetados (Lambrecht, Hammad, 2015). Mundialmente, mais de 300 milhões de pessoas são afetadas pela doença 
(GINA, 2018). O que a torna uma das doenças crônicas mais comuns no mundo. Além disso a prevalência da asma tem crescido nas últimas décadas em diversas partes do mundo (Stephen T. Holgate, 2015).

\subsection{Fisiopatologia da Asma}

$\mathrm{Na}$ asma, várias células da imunidade inata e adaptativa atuam junto com células epiteliais causando alta produção de muco, remodelamento da parede das vias aéreas, estreitamento das vias aéreas e hiperresponsividade brônquica - esta última definida como uma propriedade das vias aéreas de contrair mais facilmente e forçadamente do que vias aéreas normais em resposta a variadade de estímulos (Lambrecht, Hammad, 2015; Côté, Turmel, \& Boulet, 2018).

Duas formas de asma têm sido bem definidas na clínica. A maioria das crianças e aproximadamente $50 \%$ dos adultos apresentam a asma alérgica, a qual está relacionada com a sensibilização a um alérgeno, definida pela presença da imunoglobulina $E(\lg E)$. A segunda forma de asma que tem sido definida é a não alérgica, que frequentemente se desenvolve mais tardiamente. Essa forma de asma não está relacionada com a presença de altos níveis de $\lg$ E, tampouco, envolvimento com respostas imunes de perfil Thelper 2 (Th2). Esses pacientes apresentam inflamação neutrofílica, com poucas obstruções reversíveis das vias aéreas e presença de padrão de citocinas Th1 e Th17, porém seus mecanismos fisiopatológicos ainda não estão muito bem elucidados. Essa forma de doença é mais comum em mulheres e está associada com rinite 
crônica e pólipos nasais, assim como obesidade e é de difícil tratamento (Lambrecht, Hammad, 2015).

A inflamação crônica presente na asma alérgica é predominantemente orquestrada pela resposta Th2, caracterizada por altos níveis de $\operatorname{lgE}$, eosinofilia brônquica, infiltrado de células TCD4+ nas vias aéreas e produção de citocinas Th2 (Interleucina (IL)-4, IL-5, IL-13), além do remodelamento das vias aéreas, caracterizado pelo aumento de fibras colágenas e elásticas, hipertrofia da musculatura lisa peribrônquica, aumento da vascularização, hipertrofia epitelial e das glândulas secretoras de muco (Vieira, et al, 2007).

A primeira etapa para o desenvolvimento da asma alérgica é a sensibilização a um antígeno (alérgeno). As células dendríticas são as apresentadoras de antígenos mais importantes no pulmão e são principalmente reconhecidas por seu potencial de gerar uma resposta imune primária e sensibilização a alérgenos inalados (Van Rijt, Lambrecht, 2005).

As células dendríticas pulmonares são especializadas na apresentação antigênica e são essenciais no balanço imunológico das vias aéreas, desempenhando um papel importante tanto na indução como na manutenção da asma (Hammad, Lambrecht, 2009). Elas residem próximo ao epitélio, em estado imaturo, onde monitoram o lúmen da via aérea e são especializadas em capturar antígenos. Diferentes tipos de células dendríticas podem ser encontrados no interstício pulmonar: células dendríticas plasmocitóides (pDCs) e células dendríticas convencionais (cDCs), que por sua vez são subdivididas em cDC CD103+ (CD, do inglês Cluster of Differentiation), cDC CD11b+e cDC CD8a+, sendo esta última também chamada de célula dendrítica linfoide (Lambrecht, Hammad, 2015). 
As células dendríticas pulmonares processam e apresentam os antígenos inalados capturados para os linfócitos T naive. Na presença de IL-4, secretada principalmente pelas células dendríticas, graças ao tipo de antígeno apresentado via complexo principal de histocompatibilidade de classe II (MHC de classe II), ocorrerá a diferenciação de linfócitos TCD4 naive para linfócitos Th2 (Shum, et al, 2008).

Outro tipo celular capaz de liberar citocinas de padrão Th2, são as ILC2 (Innate lymphoid cell do tipo 2), que foram inicialmente classificadas como nãoT e não-B efetoras. Essas células se assemelham as células Th2 produzindo citocinas como IL-4, IL-13, IL-5 e IL-9 e reagem as citocinas derivadas do epitélio: IL-25, IL-33 e TSLP (Thymic Stromal Lymphopoietin) (Lambrecht, Hammad, 2015; Vieira, et al, 2007; Van Rijt, Lambrecht, 2005; Hammad, Lambrecht, 2008; Shum, et al, 2008; Gour \& Karp, 2015).

As células epiteliais das vias aéreas são responsivas a vários mediadores envolvidos na asma e estas células quando ativadas expressam diversas quimiocinas, citocinas e outros mediadores que promovem tanto a inflamação como o remodelamento das vias aéreas. As citocinas de padrão Th2, IL-4, IL-9 e IL-13, promovem a hiperreatividade das vias aéreas, secreção de muco e secreção de citocinas pelo epitélio celular (Shum, et al, 2008).

A secreção IL-4 e IL-13 e expressão de CD40L estimulam a produção de IgE pelos linfócitos B (Van Rijt, Lambrecht, 2008). A IgE, produzida por linfócitos $B$, liga-se nos receptores de alta afinidade FcERI dos mastócitos, promovendo ativação do mesmo. Sendo assim, quando os mastócitos são ativados por uma ligação cruzada antígeno-dependente e receptores de $\lg \mathrm{E}$, ocorre a 
degranulação, liberando citocinas como TNF-a, IL-4 e IL-13 (Shum, et al, 2008). TNF a é uma citocina pró-inflamatória produzida, principalmente, por monócitos e macrófagos (Shum, et al, 2008). Já as citocinas IL-4 e IL-13, induzem a expressão de moléculas de adesão no endotélio inflamado e a produção epitelial de quimiocinas, favorecendo o recrutamento de células inflamatórias (Van Rijt, Lambrecht, 2008).

Os mastócitos promovem diversos efeitos biológicos partir da sua ativação, que são mediados por aminas biogênicas (ou aminas vasoativas) que são liberadas também dos grânulos citoplasmáticos dos mastócitos. Nos humanos, o principal mediador desta classe é a histamina (Abbas, 2015). A histamina causa broncoespasmo e aumenta a permeabilidade vascular (Kumar, 2006). Os mediadores lipídicos liberados a partir da degranulação dos mastócitos são os leucotrienos e prostaglandinas. Os leucotrienos causam broncoconstrição prolongada, aumentam a permeabilidade vascular e a secreção de mucina enquanto que a prostaglandina promove a broncoconstrição e a vasodilatação (Kumar, 2006). A prostaglandina também promove a quimiotaxia e acúmulo de neutrófilos nos locais de inflamação (Jadl, et al, 2016). Esses mediadores abrem as junções intercelulares da mucosa, permitindo a penetração dos antígenos e um número maior de mastócitos na mucosa. A estimulação direta dos receptores vagais subepiteliais (parassimpáticos) provoca broncoconstrição reflexa por meio de reflexos centrais e locais. Isso ocorre em minutos após a estimulação, sendo denominada resposta aguda ou imediata, que consiste em broncoconstrição, edema (devido ao aumento da permeabilidade vascular) e secreção de muco (Kumar, 2006). 
Em camundongos, a citocina IL-4 é necessária para o desenvolvimento da resposta Th2 e produção de anticorpos IgG1 e lgE bem como para a migração de eosinófilo. A IL-13 é necessária e suficiente para manter a hiperresponsividade brônquica e metaplasia das células Globet, processo onde as células epiteliais se transdiferenciam e começam a produzir muco espesso contendo as mucinas MUC5AC e MUC5B, capaz de obstruir as vias aéreas (Lambrecht, Hammad, 2015).

Outro tipo celular envolvido são os eosinófilos. Estas células são estimuladas por IL-5 e CCL11 (Eotaxina -1) e outras citocinas que os atraem para as vias aéreas (Shum, et al, 2008). A IL-5 é importante para o crescimento, diferenciação e ativação dos eosinófilos do tecido (Van Rijt, Lambrecht, 2008). O acúmulo de eosinófilos acaba por gerar um ambiente tóxico para o epitélio celular (Shum, et al, 2008). Os eosinófilos presentes no pulmão também são recrutados para a mucosa, bem como para o interstício, pela ação de CCL24 e CCL26 (Lambrecht, Hammad, 2015).

Os macrófagos pulmonares (alveolar e intersticial) são reguladores da homeostase no pulmão e da inflamação frente a alérgenos inalados. Semelhante às células $T$, os macrófagos pulmonares na presença de citocinas IL-4 e IL-13 polarizam em fenótipos diferentes, tornando-se macrófagos M2. Em contraste, frente a citocinas de padrão Th1, vírus e microrganismos, induzem a diferenciação para macrófago M1. Apesar de ambos, M1 e M2, serem encontrados nos pulmões durante o curso da inflamação na asma, estudos mostram um incremento de macrófagos M2 nos pulmões de pacientes asmáticos, se comparados a pessoas sadias. Além disso, esse aumento de M2 
está relacionado com o declínio da função pulmonar (Abreu, et al, 2017). Outro papel desempenhado pelo macrófago M2 no pulmão é imunomodular a inflamação negativamente, via a produção de IL-10 e TGF- $\beta$ (Zdrenghea, et al, 2015).

Os linfócitos T reguladores ou Treg também apresentam papel importante na asma, pois também regulam negativamente a ativação e diferenciação das células $\mathrm{T}$ naive CD4. Essas células surgem de uma via distinta de desenvolvimento, a qual depende da produção de TSLP (Thymic Stromal Lymphopoietin), produzido da medula do timo. O TSLP é capaz de estimular as células dendríticas, que são necessárias para o desenvolvimento dos linfócitos Treg (Shum, et al, 2008).

Os efeitos inibitórios promovidos pelos linfócitos Treg se dão pela secreção de citocinas imunossupressoras como IL-10 e TGF- $\beta$. Essas citocinas são capazes de suprimir a ativação de células dendríticas pulmonares e através da direta interação com células endoteliais, portanto impedindo a angiogênese. Outro mecanismo possível envolve a produção de IL-35 por Treg ICOS+ que tem o potencial de suprimir a hiperresponsividade induzida por IL-17 em camundongos (Lambrecht, Hammad, 2015). .

Existem evidências de que as Treg podem controlar as respostas Th2 em humanos, pela produção destas citocinas. Além disso, foi demonstrado que suprimem a ativação e diferenciação dos linfócitos TCD4 naive (Shum, et al, 2008). 


\subsection{Imunologia do Exercício}

O exercício físico promove efeitos modulatórios no sistema imune. Esses efeitos são mediados por diversos fatores incluindo indução de liberação de citocinas pró-inflamatórias, hormônios do estresse e efeitos hemodinâmicos, conduzindo a redistribuição celular. A natureza das interações são complexas, com modificação de expressão de moléculas de adesão, recrutamento seletivo de linfócitos maduros e não naive e alterações em apoptose e potencial mitótico (Pedersen, Toft, 2000).

Existem diversos mecanismos aos quais o exercício físico agudo e crônico afetam a imunidade inata. Há fatores que podem ser induzidos pelo exercício físico, como o estresse oxidativo, aumento da taxa metabólica, proteínas de choque térmico, catecolaminas, cortisol e fator de crescimento semelhante a insulina que podem influenciar a imunidade inata no reconhecimento de patógenos alterando a expressão de moléculas de reconhecimento, como tolllike, o tráfico de células pela alteração da hematopoiese, morte celular, expressão de moléculas de adesão, efeitos efetores como explosão oxidativa, expressão de citocinas e processamento e apresentação antigênica (Walsh, et al, 2011).

A prática de exercício físico também pode interferir em alguns mecanismos da imunidade adquirida, mudando o número de linfócitos circulantes. Potenciais mecanismos aos quais o exercício físico agudo e crônico podem afetar a imunidade adquirida, estão relacionados com a ação da 
adrelanina que leva a mobilização de células B e T, estão ligadas diretamente na expressão de moléculas de adesão (integrina e selectina) e indiretamente via sistema simpático, influenciando o débito cardíaco e subsequente aumento da pressão e associado com o aumento do fluxo sanguíneo (Walsh, et al, 2011).

O exercício físico aeróbio pode modular as respostas imunes em indivíduos saudáveis: nas intensidades baixa e moderada favorecem ao aumento da resposta imunológica moduladora enquanto que a atividade aeróbia de alta intensidade parece bloquear este efeito protetor (Vieira, et al, 2007; Pedersen, Holfman, 2000; Woods, 2000; Woods, 2003).

Em indivíduos sadios, a atividade física modula o sistema imune aumentando respostas Th1, o que parece suprimir Th2. Interferon- $\gamma$ (IFN- $\gamma$ ) expresso por linfócitos Th1 por indivíduos aerobicamente treinados suprime a proliferação de linfócitos Th2 (Silva, et al, 2010). Apesar dos efeitos conhecidos do exercício físico em indivíduos saudáveis, poucos estudos investigaram os mecanismos responsáveis pelo seu efeito sobre as respostas alérgicas e inflamatórias (Smith, 2003; Zieker, et al, 2005).

Sabe-se que o treinamento de intensidade moderada tem a capacidade de regular o sistema imune, com aumento de capacidade fagocítica de neutrófilos e macrófagos além de diminuição da eosinofilia e do remodelamento no pulmão (Vieira, et al, 2008). Entretanto, ainda se encontram obscuros os mecanismos celulares envolvidos nesta regulação. 


\subsection{Asma e Exercício}

$\mathrm{Na}$ população em geral acometida pela asma o exercício físico é estigmatizado, onde muitos asmáticos experienciam muitos sintomas respiratórios como a falta de ar e aperto no peito durante o exercício. Consequentemente, asmáticos geralmente apresentam baixa aptidão física para realizar exercicios físicos quando comparado a não asmáticos. (Adams et al., 2004; Kullowatz, Kanniess, Dahme, Magnussen, \& Ritz, 2007; Cluley \& Cochrane, 2001). Além disso, muitos asmáticos controlados podem viver uma vida ativa normal e portanto, a habilidade de realizar exercícios físicos tem sido mais frequentemente relacionada com hábitos de realizar exercícios físicos e fatores fisiológicos, como o ganho de condicionamento, do que com a obstrução de vias aéreas ou hiperresponsividade. (Côté et al., 2018; Clark \& Cochrane, 1988). O exercício físico regular pode não somente manter a qualidade da saúde, como melhorar o controle da asma do paciente (Pedersen BK, 2015).

O treinamento aeróbio vem sendo usado em diversos programas de reabilitação para pacientes asmáticos, gerando diminuição da dispneia, de hiperresponsividade de vias aéreas, de indução de broncoespasmos e até do uso de corticosteroides. Além disso, esses pacientes apresentam melhora da capacidade aeróbia e qualidade de vida (Silva, et al, 2010; França-Pinto, et al, 2015).

Alguns autores já mostraram que o exercício físico aeróbio pode diminuir a inflamação pulmonar alérgica em animais sensibilizados e sugeriram que esta redução pode ocorrer por inibição da ativação do fator nuclear (NF-kB), ou por 
aumento na expressão de citocinas antinflamatórias, como IL1-ra e IL-10 (Silva, et al, 2010; Olivo, et al, 2014; Silva, et al, 2014).

Outros estudos de Mackenzie et al (2016), demonstraram que animais sensibilizados a ovalbumina e submetidos a um protocolo de treinamento experimental apresentam redução de níveis citocinas Th2 IL-4, IL-5 e IL-13 nos linfonodos mediastinais. Além disso, esse mesmo estudo demonstrou que o exercício físico inibe a maturação e ativação de células dendríticas, indicando que a diminuição da resposta Th2 presente nos animais sensibilizados e treinados pode ser devido a algum interferente na maturação da célula apresentadora do antígeno OVA durante o exercício.

Tendo em vista este contexto, trabalhamos neste estudo com a hipótese que o exercício físico moderado gere maior ativação de células regulatórias, reduzindo assim a inflamação pulmonar. Para checarmos nossa hipótese de que o exercício físico apresenta um papel anti-inflamatório na inflamação alérgica pulmonar propomos este estudo visando investigar o papel de células imunomoduladoras como $\mathrm{T}$ reguladoras e pDCs na imunomodulação induzida pela atividade física aeróbia em animais com inflamação pulmonar alérgica crônica. 


\section{OBJETIVOS}

\subsection{Gerais}

Investigar os mecanismos imunomoduladores induzidos pela atividade física aeróbia em animais com inflamação pulmonar alérgica crônica.

\subsection{Específicos}

1. Avaliar a estrutura e função pulmonar através de remodelamento pulmonar e responsividade brônquica;

2. Quantificar os mediadores inflamatórios envolvidos como citocinas e a produção de anticorpos antígeno-específicos;

3. Avaliar o perfil inflamatório no pulmão e linfonodos, em especial o grau de ativação e perfis dos diversos subtipos de células inflamatórias. 


\section{MÉTODOS}

\subsection{Animais}

Foram utilizados camundongos Balb/c ( $n=8 /$ grupo), machos, com idade entre 6 e 8 semanas, livres de patógenos específicos (SPF) provenientes do Biotério Central da Faculdade de Medicina da USP. Antes da realização dos experimentos, os animais foram mantidos em condições controladas de temperatura e iluminação (ciclo claro/escuro de 12 horas) com água e ração ad libitum. Todos os animais receberam cuidados de acordo com o "Guia de cuidados e uso de animais de Laboratório" publicado por National Institutes of Health (NIH, 2011). Este protocolo experimental foi aprovado pelo Comitê de Ética em Pesquisa (CEP) da Faculdade de Medicina da USP (Protocolo132/13).

\subsection{Indução da Inflamação Alérgica Pulmonar}

A sensibilização antigênica se deu por via intraperitoneal (i.p.) com $20 \mu \mathrm{g}$ de OVA grau V adsorvida 250 g de hidróxido de alumínio - Alumen (Pepsamar, 
Sanofi-Synthelabo S.A., Rio de Janeiro, Brasil) em um volume total de 0,2 ml nos dias $0,14,21,28$ e 42 . Para o desafio antigênico, os animais foram acondicionados em uma caixa de exposição acoplada a um nebulizador

ultrassônico (Pulmoclear II, Soniclear, São Paulo, Brasil) e submetidos à inalação de OVA diluída em $\mathrm{NaCl}$ 0,9\% na concentração de $10 \mathrm{mg} / \mathrm{ml}$ (1\%), por 30 minutos, três vezes por semana a partir do dia 21 até o dia 51. Os grupos controle foram imunizados somente com adjuvante e foram expostos a aerossol de solução salina $0,9 \%$ por 30 minutos nos dias de desafio antigênico. 0 protocolo experimental adaptado de Vieira et al (2007), encontra-se esquematizado na figura 1.

\subsection{Teste físico e treinamento aeróbico}

O treinamento aeróbio foi realizado por um período de 5 semanas em esteira ergométrica adaptada para camundongos (modelo KT 400, marca Imbramed, RS, Brasil) seguindo o protocolo previamente estabelecido (Vieira, et al, 2007). Na semana anterior ao início do treinamento, os animais foram submetidos a 3 dias de adaptação na esteira ergométrica (5 minutos, com inclinação de 25 graus e à velocidade de $0,2 \mathrm{~km} / \mathrm{h}$ ). Vinte e quatro horas após este período de adaptação, os animais foram submetidos a um teste de esforço máximo. O teste consiste em 5 minutos de aquecimento a $0,2 \mathrm{~km} / \mathrm{h}$ e a 
velocidade foi aumentada gradativamente em $0,1 \mathrm{~km} / \mathrm{h}$ a cada 2,5 minutos até que $o$ animal se apresentasse exausto. A exaustão foi considerada no momento em que o animal não conseguiu permanecer correndo mesmo após 10 estímulos mecânicos. A intensidade do treinamento foi moderada, ou seja, $50 \%$ da velocidade máxima média atingida no teste de esforço. $O$ treinamento foi realizado cinco vezes por semana, 60 minutos por sessão, durante cinco semanas a partir do dia 21 , sempre aproximadamente 1 hora antes do desafio antigênico. Ao término do protocolo de treinamento no dia 51 , o teste físico foi repetido para que se pudesse reavaliar o condicionamento físico dos animais (Figura 1).

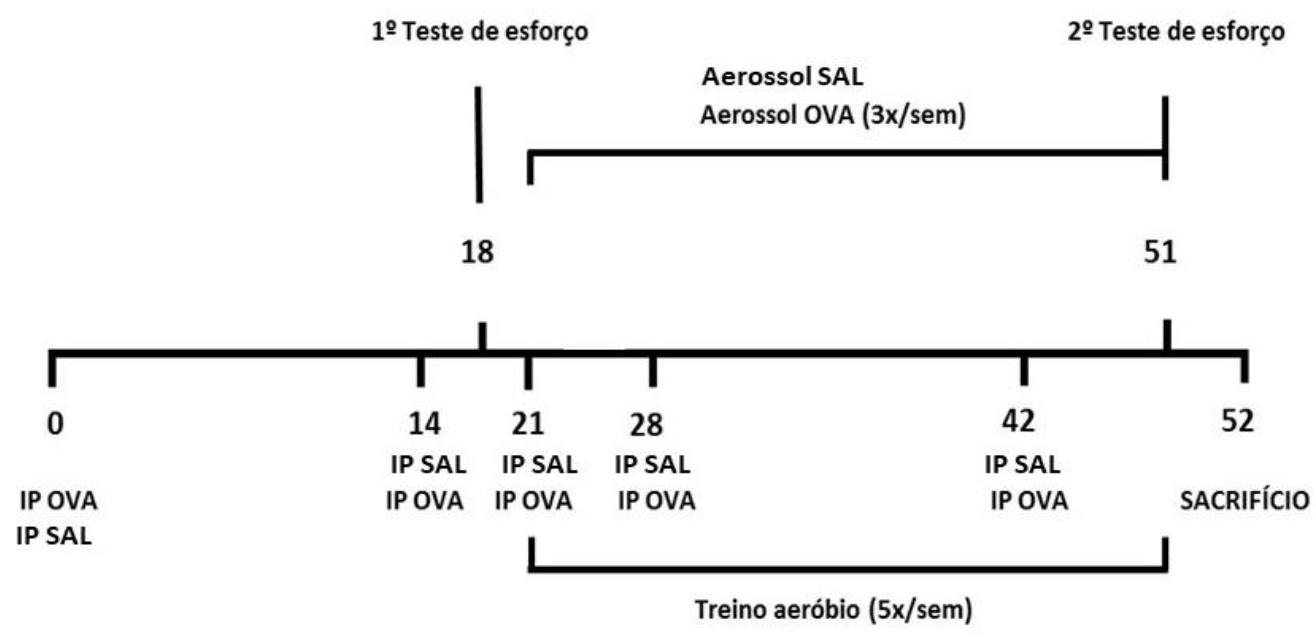

Figura 1 - Esquema do protocolo experimental. 


\subsection{Grupos Experimentais}

Os animais foram divididos em quatro grupos experimentais:

- SAL: Animais não sensibilizados e não treinados.

- EX: Animais não sensibilizados e treinados em esteira.

- OVA: Animais sensibilizados à OVA e não treinados.

- OEX: Animais sensibilizados à OVA e treinados.

Os experimentos foram realizados repetidamente em três lotes distintos de animais, sendo que o primeiro deles foi direcionado à avaliação da mecânica pulmonar, titulação de anticorpos, avaliação morfométrica pulmonar, o segundo lote para quantificação de citocinas e o terceiro foi fracionado e direcionado à avaliação do perfil celular por citometria de fluxo. Não houve perdas de animais durante o protocolo experimental.

\subsection{Avaliação da Mecânica Pulmonar}

Vinte e quatro horas após o último desafio, os animais ( $n=8 /$ grupo) foram anestesiados com thiopental sódico $(70 \mathrm{mg} / \mathrm{kg})$, traqueostomizados e ventilados 
mecanicamente (150 ciclos por minuto, $10 \mathrm{ml} / \mathrm{Kg}$, Harvard 687, Harvard Apparatus, Holliston, MA) em um pletismógrafo de acrílico. Os sinais de pressão traqueal e o volume pulmonar foram adquiridos através de transdutores diferenciais de pressão (Honeywell 163PC01D36, Freeport, IL) e convertidos por placa analógica digital (DT01EZ, Data Translation, Malboro, MA). Os valores de elastância e resistência do sistema respiratório foram calculados através da equação do movimento do sistema respiratório, descrita a seguir:

$$
\operatorname{Ptr}_{(t)}=\operatorname{Rrs} \cdot V_{(t)}^{\prime}+E r s \cdot V_{(t)}
$$

Onde: t é tempo; Ptr é pressão traqueal; Rrs é resistência do sistema respiratório; Ers é elastância do sistema respiratório; $V^{\prime}$ é fluxo aéreo e $V$ é o volume pulmonar. Foram calculados os valores de Rrs e Ers basais e máximos após a administração de doses crescentes de aerossol de metacolina (3, 30 e $300 \mathrm{mg} / \mathrm{ml}$, por 1 minuto).

\subsection{Coleta de Sangue para quantificação de Imunoglobulinas}

Após a avaliação de mecânica pulmonar, foi realizada a coleta do sangue dos animais através da veia cava abdominal. Foram obtidos $0,3 \mathrm{ml}$ de sangue e diluídos em $300 \mu \mathrm{l}$ de solução de $\mathrm{NaCl}$ 0,9\%. O sangue foi centrifugado a 3000 rpm por 10 minutos para obtenção do soro. $\mathrm{O}$ soro foi aconcidionado a $-80{ }^{\circ} \mathrm{C}$ para posterior quantificação de imunoglobulinas. 
Após a coleta do sangue, os animais foram eutanasiados por secção da aorta abdominal.

\subsection{Homogenato do tecido pulmonar e análise histológica}

Os pulmões dos animais foram então removidos em monobloco. 0 pulmão direito foi removido e homogeneizado em solução $\mathrm{NaCl} 0,9 \%(600 \mu \mathrm{L})$, usando-se beads de metal, conforme recomendações do fabricante (Powerlyzer, MoBio Laboratories Inc, USA). O homogenato foi armazenado a $-80{ }^{\circ} \mathrm{C}$ para posterior quantificação de citocinas.

O pulmão esquerdo foi insuflado com $50 \%$ do volume corrente e fixado em formaldeído (4\%) por 24 hs e então foi submetido a processamento histológico de rotina. Para análise e quantificação, as células produtoras de muco foram identificadas pela coloração com ácido periódico de Schiff (PAS). Todos os cortes foram examinados usando microscópio Zeiss Axiophot (Zeiss, Oberkochen, Germany) com uma ampliação de 1000x. Foram analisadas cinco vias aéreas por lâmina. 


\subsection{Dosagem de citocinas por ELISA}

Os níveis de IL-4, IL-6, TGF- $\beta$ e IL-10 nas amostras foram determinados por ELISA (OptEIA, BD PharMingen, Oxford, UK) onde microplacas (Costar, Cambridge, MA, USA) para cada citocina foram sensibilizadas com anticorpos monoclonais específicos. Após lavagem e distribuição das amostras, foram adicionados anticorpos específicos para as diferentes citocinas conjugados à biotina. Para a revelação da ligação, solução reveladora contendo conjugado enzimático de estreptoavidina-peroxidase, substrato e cromógeno foi adicionada. A leitura da reação foi realizada a $450 \mathrm{~nm}$ em espectrofotômetro M2 (Spectramax L, Moleculas Devices). As concentrações das amostras foram calculadas a partir das curvas-padrão obtidas com as citocinas recombinantes.

\subsection{Desagregação do tecido pulmonar e linfoide}

Para a avaliação do perfil inflamatório por citometria de fluxo, os animais foram eutanasiados com injeção letal de thiopental sódico $(80 \mathrm{mg} / \mathrm{kg})$. Os animais foram exanguinados pela secção da aorta. Retiramos então os pulmões e linfonodos drenantes mediastinais. O tecido pulmonar foi fragmentado em pequenas partes, mantido numa solução que contém enzimas colagenase 
(Sigma-Aldrich, $0.7 \mathrm{mg} / \mathrm{mL}$ ) e DNAse (Sigma-Aldrich, $30 \mu \mathrm{g} / \mathrm{mL}$ ) por 30 minutos a $37^{\circ} \mathrm{C}$ para digestão do tecido pulmonar. Após a digestão, com o auxílio de uma membrana de nylon com malhas de $55 \mu \mathrm{m}$ (BD, San Diego, CA), o tecido pulmonar foi desagregado e a suspensão celular foi resuspendida em $1 \mathrm{ml}$ de solução $\mathrm{NaCl}$ 0,9\%. A suspensão celular foi contada com o auxílio de câmara de Neubauer e ajustada para $5 \times 10^{6}$ células $/ \mathrm{ml}$ em solução de $\mathrm{NaCl} 0,9 \%$ e misturada em tubos de poliestireno sob agitação foi incubada com os anticorpos marcados com fluorocromos para análise por citometria de fluxo.

Para a desagregação dos linfonodos mediastinais não foi necessária a utilização de enzimas digestivas, portanto, foi somente utilizada a membrana de nylon com malhas de $55 \mu \mathrm{m}$ (BD, San Diego, CA) para desagregação do tecido e a suspensão celular foi obtida resuspendida em $1 \mathrm{ml}$ de solução $\mathrm{NaCl}$ 0,9\%. A contagem celular foi realizada assim como no tecido pulmonar.

\subsection{Citometria de Fluxo}

As diferentes populações celulares foram identificadas pelo uso de anticorpos monoclonais específicos marcados com fluorocromos. Inicialmente, as células foram incubadas com o anticorpo anti-CD16/CD32 (2.4G2) por 10 minutos a temperatura ambiente, visando bloquear marcações inespecíficas. Após lavagem, $1 \times 10^{6}$ células $/ 100 \mu \mathrm{L}$ foram incubadas com anticorpos conforme a tabela 1: anti-CD3 (145-2C11), anti-CD4 (RM4-5), anti-CD11b (M1/70), anti- 
CD11c (HL3), anti-CD19 (1D3), anti-CD25 (PC61), anti-CD69 (H1.2F3), antiCD117 (2B8), anti-CD193 (83103), anti-CD45R/B220 (RA3-6B2), anti-MHC de classe II (M5/114.15.2) e anti-SIGLEC-F (E50-2440), anti-CD24 (M1/69), antiPDL2 (TY25), anti-ICOL (HK5.3), anti-PDCA1 (Ebio97), anti-CD8a (53-6.7) e marcador de viabilidade por $30 \mathrm{~min}$ a $4{ }^{\circ} \mathrm{C}$, posteriormente as células foram lavadas e fixadas em $100 \mu \mathrm{L}$ formaldeído $1 \%$ e acondicionadas a $4{ }^{\circ} \mathrm{C}$. Após vinte e quatro horas, para a marcação intracelular de FOXp3, LAP e IL-10, as células foram primeiramente permeabilizadas com saponina 0,05\% (SigmaAldrich) e incubadas com os respectivos anticorpos anti-FOXp3 (MF23), antiLAP (TW7-16B4), anti-IL-10 (JESS-16E3), (todos da BD-Pharmingen, San Diego, CA, USA) por 30 minutos a $4^{\circ} \mathrm{C}$, posteriormente lavadas, ressuspendidas em PBS no volume de $250 \mu \mathrm{L}$ e acondicionadas a $4{ }^{\circ} \mathrm{C}$ para leitura no citômetro de fluxo Fortessa (BD Biosciences). Os eventos (10.000) foram adquiridos com o programa BD FACS DIVA e analisados com programa Flow Jo 10.0.6. (Tree Star, Ashland, OR, USA). Os resultados foram expressos em porcentagem de células positivas ou intensidade média de fluorescência para cada molécula avaliada, assim como valores absolutos. A fenotipagem celular utilizada pode ser observada na Tabela 1.

Tipo Celular

Eosinófilo

M1 (macrófago intersticial/ pró-

inflamatório)

M2 (macrófago alveolar/residente)

Linfócito T CD4
Marcação

CD3- B220- MHCII- SIGLECF+

Cd11bMed F4/80Low CD11c+ MHCII+

SIGLECF-

F4/80Hi CD11C+ MHCII+ SIGLECF+ CD3+ CD4+ expressão de CD69

(ativação) 
Linfócitos T CD8

Linfócito Treg CD4

Linfócito Treg CD8

pDC

cDC
CD3+ CD8+ expressão de CD69

(ativação)

CD3+ CD4+ CD25+ e expressão de

FOXP3, IL-10 e LAP

CD3+ CD8+ CD25+ e expressão de

FOXP3, IL-10 e LAP

CD11c- MHCll+ CD24+ B220+ PDCA+

expressão de CD86, ICOSL, PDL2

$\mathrm{CD} 11 \mathrm{c}+\mathrm{MHCll}+\mathrm{CD} 24+\mathrm{CD} 11 \mathrm{~b}+\mathrm{B} 220+$

expressão de CD86, ICOSL, PDL2

Tabela 1 - Marcação celular para avaliação por citometria de fluxo Marcação celular a ser considerada para caracterização de perfil celular nos compartimentos analisados (pulmão e linfonodos), em gates específicos.

\subsection{Dosagem de IgG1 e IgG2a por ELISA}

A dosagem de anticorpos foi realizada pelo ensaio imunoenzimático (ELISA) indireto. Para determinação de $\lg G 1$ e IgG2a anti-OVA específicas, a microplaca foi recoberta com antígeno OVA, após incubação e lavagem, o plasma obtido de cada animal foi adicionado em uma diluição previamente determinada. Para revelar a reação foram adicionados anticorpos de detecção biotinilados específicos para lgG1 ou lgG2a, seguido de incubação e lavagem. Em seguida, a solução reveladora contendo conjugado enzimático de estreptoavidina-peroxidase, substrato e cromógeno foi adicionada. A reação de cor foi lida em espectrofotômetro (Spectra Max M2) a 490 nm e foi proporcional 
a quantidade dos isótipos na amostra. Os resultados foram expressos como a média das absorbâncias \pm erro-padrão das diluições seriadas das amostras de cada grupo.

\subsection{Dosagem de IgE por reação de anafilaxia cutânea passiva (PCA - Passive cutaneous anaphylaxis)}

A determinação de anticorpos anafiláticos lgE OVA-específicos foi feita pela reação de PCA, segundo a técnica descrita por Mota e Wong (Mota and Wong 1969). Para determinação dos anticorpos IgE, ratos depilados no dorso foram sensibilizados intradermicamente com diluições seriadas dos plasmas. Após um período de 18 a 24 horas de sensibilização, os animais foram desafiados i.v. com azul de Evans a $0,25 \%$, contendo $500 \mu \mathrm{g}$ de OVA. A leitura da reação foi feita 30 minutos após o desafio, observando-se o diâmetro da reação na pele invertida do animal. Os títulos de IgE foram expressos como a recíproca da maior diluição dos plasmas que resultou em uma reação positiva com mais de $5 \mathrm{~mm}$ de diâmetro. Todos os testes foram feitos em triplicata e diferenças entre os títulos de PCA maiores que 2 vezes foram consideradas significativa (Fox, 1976; Ishzaka, 1976). 


\subsection{Análise estatística}

As diferenças estatísticas entre os grupos experimentais foram detectadas através da análise de variância de dois fatores (sensibilização e exercício físico, Two-Way ANOVA) seguida dos testes de Tuckey ou Holm-Sidak para múltiplas comparações ou $\mathrm{t}$ de Student para comparar apenas 2 grupos (SigmaStat2.03, SPSS, Chicago, IL). Valores de $p<0,05$ foram considerados significativos. 


\section{RESULTADOS}

Com o intuito de verificar os possíveis efeitos do exercício físico em animais previamente sensibilizados ao antígeno ovalbumina, foram feitas avaliações dos parâmetros funcionais, celulares, estruturais e humorais nos diversos grupos experimentais.

\subsection{Avaliação da Capacidade Física}

Visando comprovar a eficácia do treinamento físico, submetemos os animais treinado ou não a avaliação da capacidade física. Observamos que os animais submetidos ao protocolo experimental apresentaram ganho de condicionamento físico, aumentando tanto a distância percorrida como o tempo durante o último teste físico. A diferença entre o primeiro teste físico (realizado no dia 18 do protocolo experimental) e o último (realizado no dia 51) referente ao tempo percorridos está demonstrado na figura 2 . 


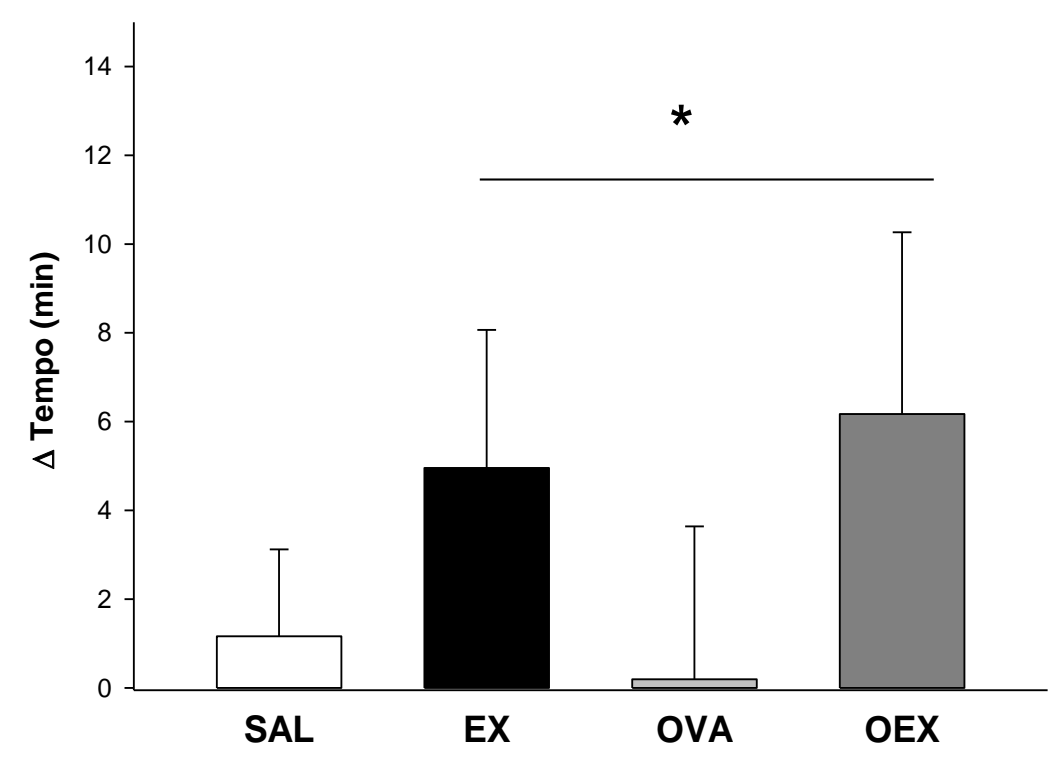

Figura 2 - 0 condicionamento físico dos animais treinados também pode ser observado ao se avaliar o tempo de treinamento. Valores médios \pm erro padrão da diferença entre os tempos máximos que os animais suportaram nos testes de esforço inicial e final. Observa-se que houve aumento do tempo percorrido pelos animais submetidos ao protocolo de treinamento físico ( $E X$ e OEX) enquanto que os animais não submetidos ao protocolo não apresentaram ganho de condicionamento físico (SAL E OVA). " $\mathrm{p}=0,05$ se comparado aos grupos não treinados.

\subsection{Avaliação da Responsividade Pulmonar}

A responsividade pulmonar foi avaliada nos animais dos diversos grupos experimentais estudados através da resposta de elastância e de resistência do sistema respiratório (figuras 4 e 5) induzida após exposição inalatória de doses crescentes do agonista broncoconstritor metacolina (Mch). 
Para a análise das curvas optamos por avaliar a área sob aa curvas, demostradas nas figuras 6 e 7. Nota-se que os animais sensibilizados à OVA apresentaram maior responsividade pulmonar, se comparados aos animais controle $(S A L)$. Os animais sensibilizados à OVA e praticantes de exercício físico moderado (OVA+EX) mantiveram elevados tanto na elastância quanto na resistência do sistema respiratório. Os animais que somente foram treinados não apresentam alterações de responsividade se comparados ao grupo controle.

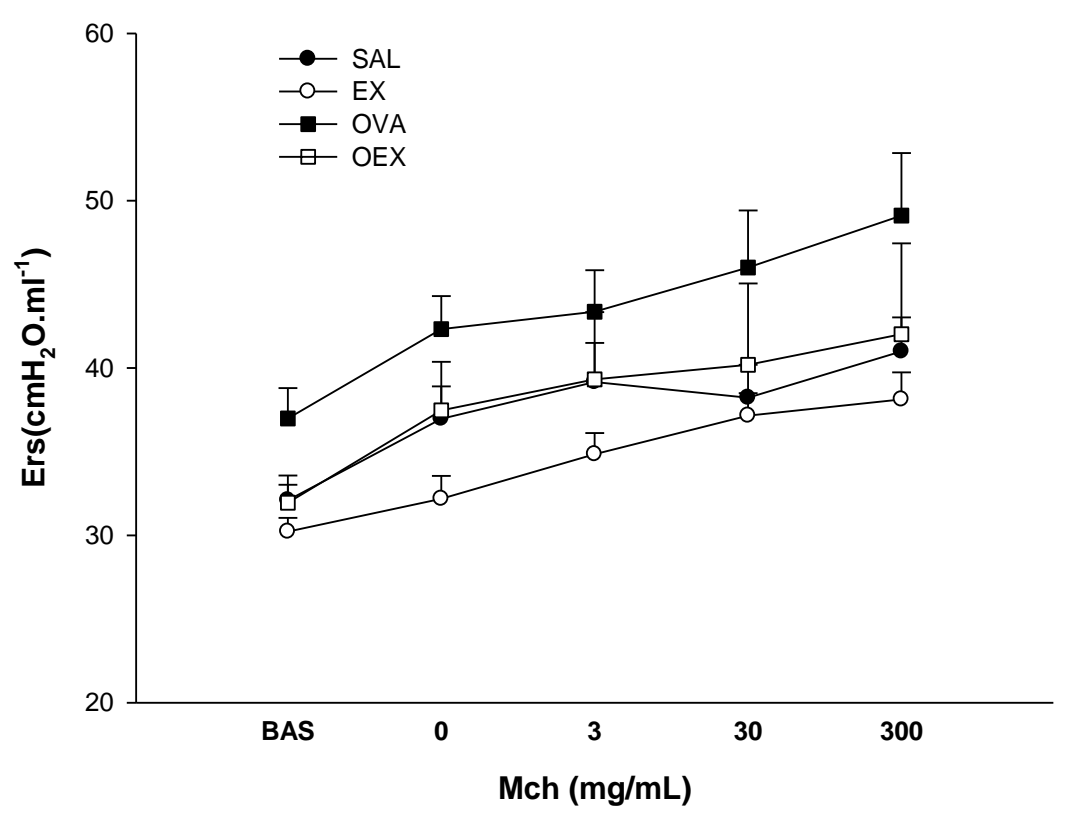

Figura 3 - Curvas dose-resposta à metacolina mostrando os valores de elastância do sistema respiratório (Ers) obtidos após a inalação de concentrações crescentes de metacolina (Mch). Valores médios \pm erropadrão dos valores de Ers obtidos. 


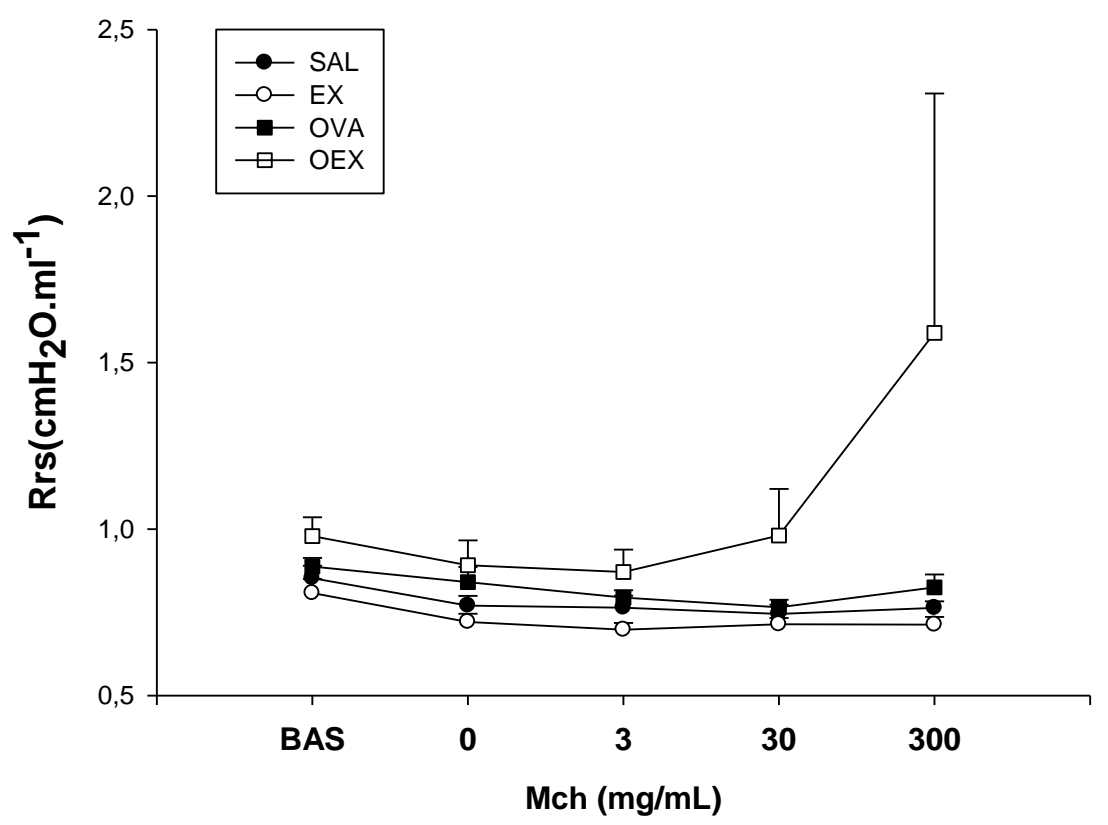

Figura 4 - Curvas dose-resposta à metacolina mostrando os valores de resistência do sistema respiratório (Rrs) obtidos após a inalação de concentrações crescentes de metacolina (Mch). Valores médios \pm erropadrão dos valores de Rrs obtidos.

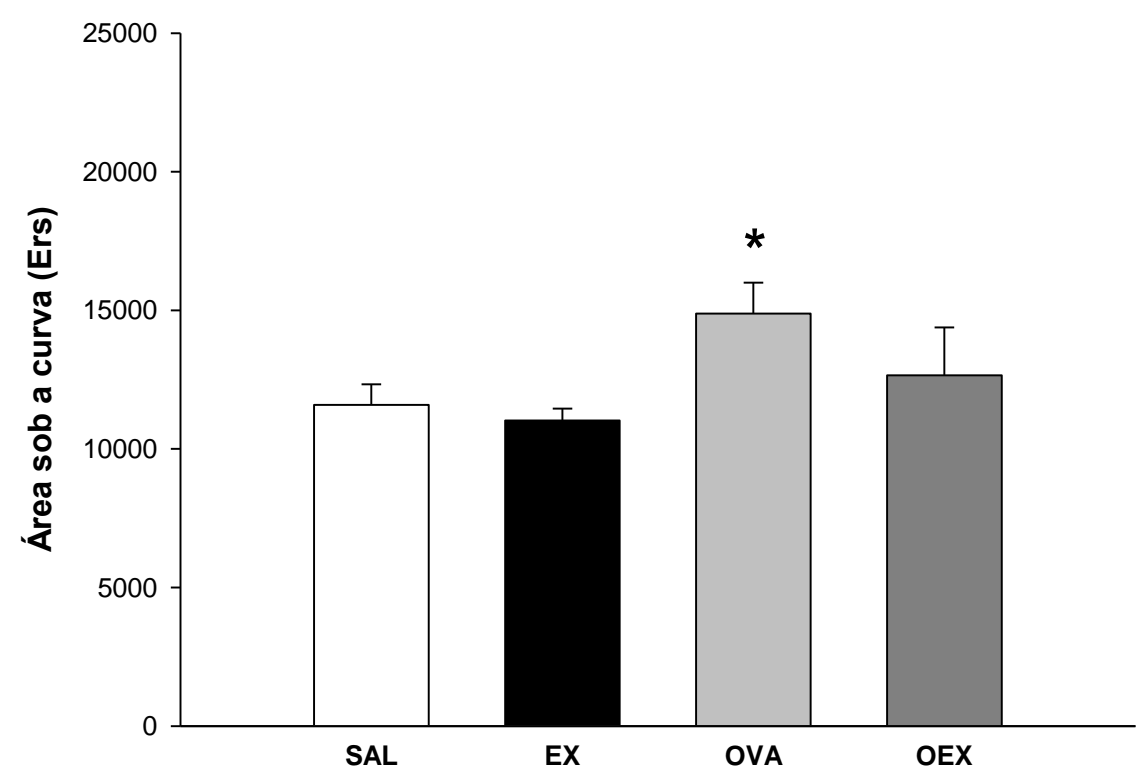

Figura 5 - Animais sensibilizados a ovalbumina apresentam hiperresponsividade quando avaliada a área sob as curvas de elastância 
do sistema respiratório e a presença da atividade física tende a reduzir essa elevação. Valores médios \pm erro-padrão dos valores de Ers obtidos. ${ }^{*} p=0,045$ comparado ao grupo SAL.

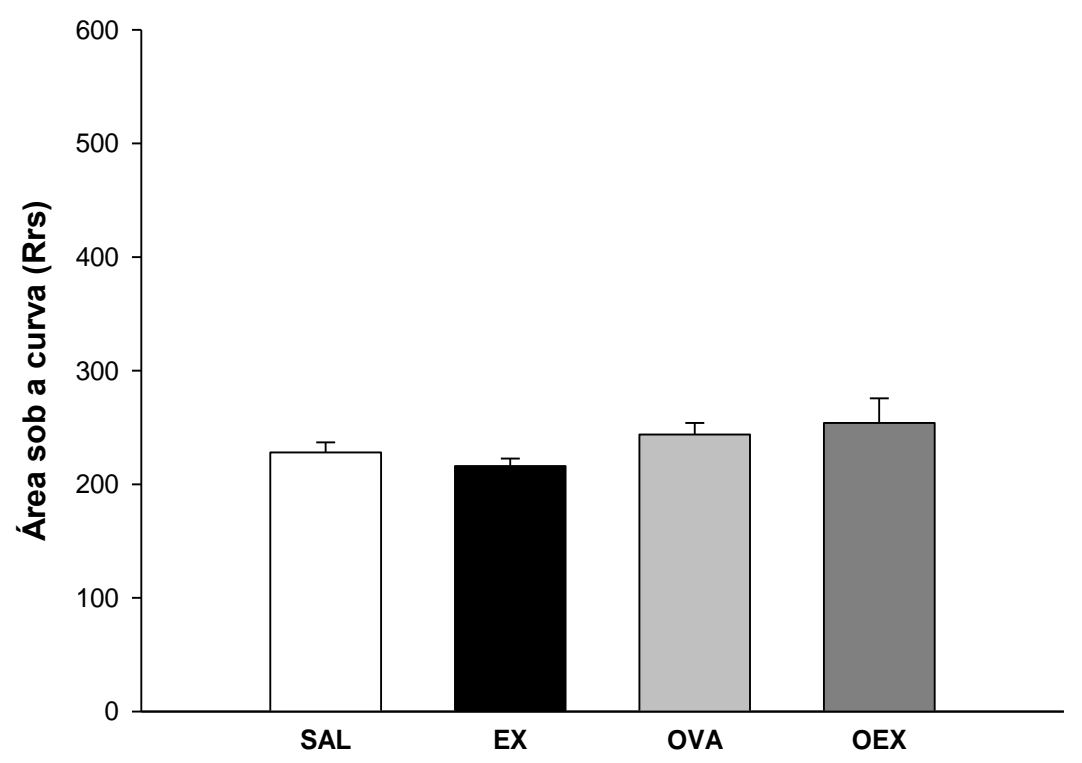

Figura 6 - Sensibilização ou exercícios físicos não alteram a responsividade proximal. Valores médios \pm erro-padrão da área sob a curva de resistência do sistema respiratório (Rrs) obtidos. Não houve diferença estatística significante entre os grupos experimentais.

4.3 Avaliação de Células Epiteliais e de Quantificação de Mucosubstâncias Intraepiteliais

Conforme demonstrado nas figuras 8 e 9, o grupo sensibilizado ao antígeno (OVA) apresenta hiperplasia/hipertrofia do epitélio brônquico conforme constatado pelo aumento da área epitelial e elevada produção de muco 
intraepitelial e o grupo sensibilizado e treinado (OEX) reduz esse quadro, indicando que a o exercício físico altera o remodelamento epitelial.

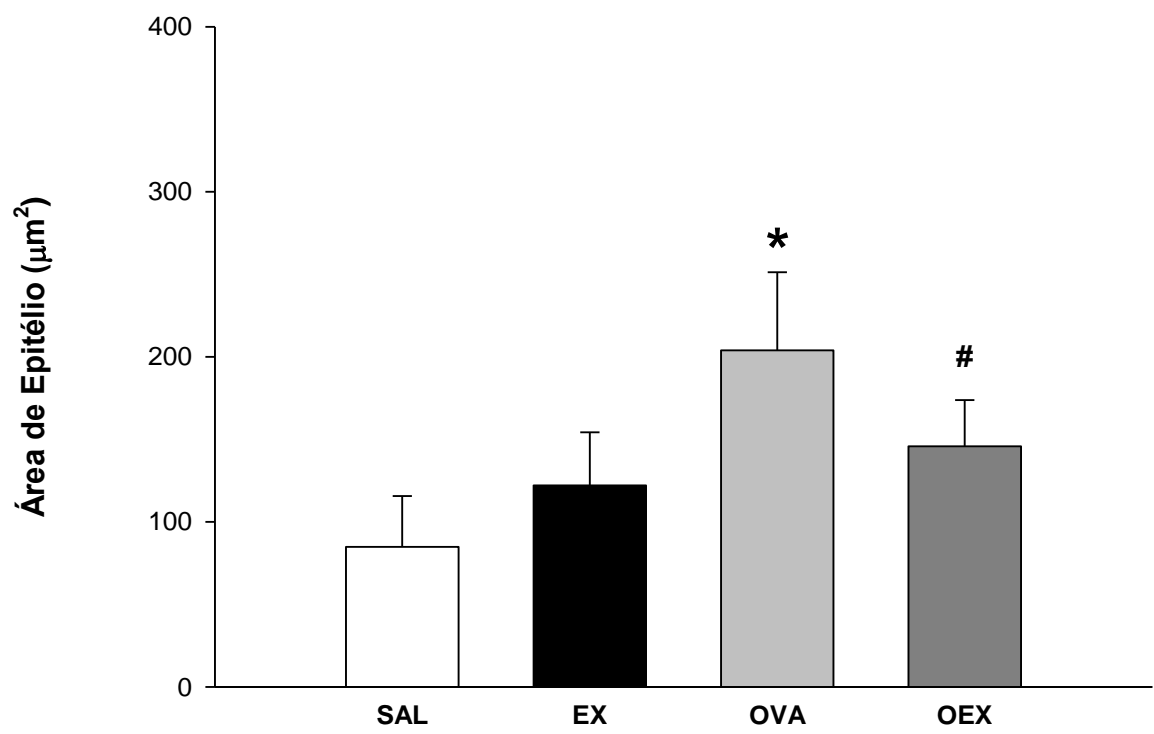

Figura 7 - A prática de exercício físico reduz a hiperplasia/hipertrofia epitelial gerada pela exposição ao antígeno OVA. Valores médios \pm erro padrão da área epitelial das vias aéreas. ${ }^{*} \mathrm{p}<0,001$ comparado ao grupo $S A L$ e $\# p=0,009$ comparado ao grupo OVA. 


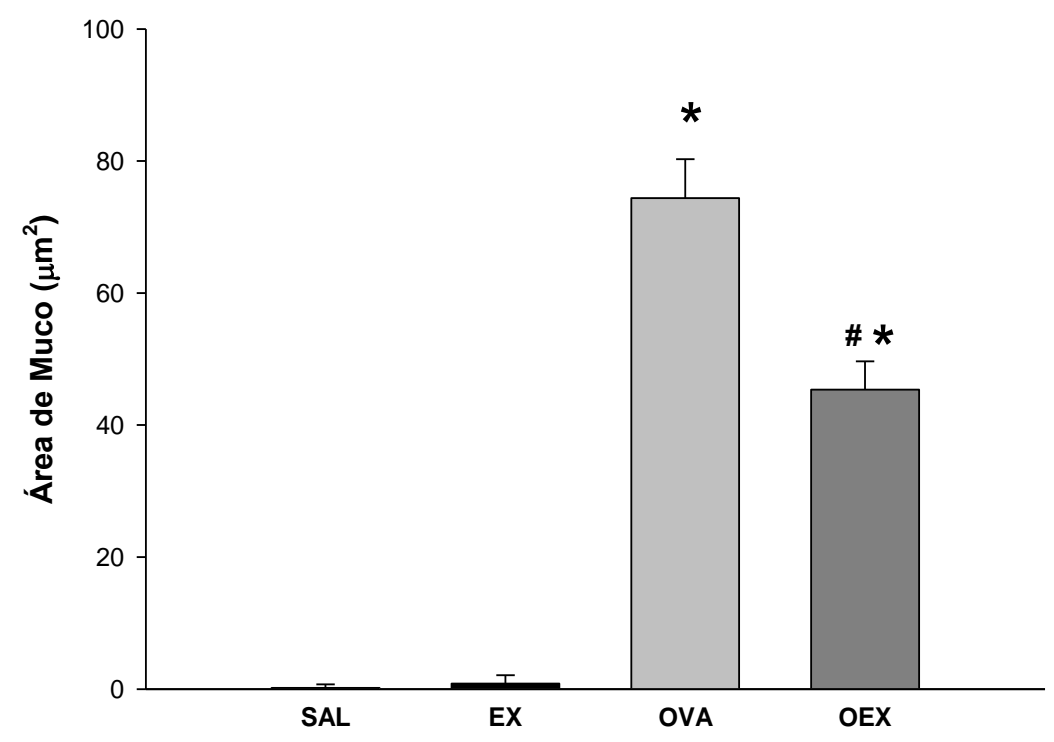

Figura 8 - A exposição ao antígeno aumenta produção de mucosubstâncias intraepiteliais e a atividade física reduz essa condição Valores médios \pm erro padrão da área de mucosubstancias encontrada no epitélio das vias aéreas. ${ }^{*} p<0,001$ comparado ao grupo SAL e \#p<0,001 comparado ao grupo OVA.

\subsection{Dosagem de Anticorpos IgG1 e IgG2a anti-OVA}

A partir dos plasmas dos animais, devidamente diluídos, foi realizado o ensaio imunoenzimático (ELISA) indireto para a quantificação de anticorpos antiOVA das classes IgG1 e lgG2a. Os resultados obtidos estão demonstrados nas figuras 10 e 11, apontam para o aumento nos níveis tanto de lgG1 quanto de IgG2a nos grupos sensibilizados à ovalbumina (OVA) e também nos grupos sensibilizados e treinados (OEX), indicando que a atividade física, como 
esperado, não altera os níveis destes anticorpos. Os demais grupos SAL e EX não obtiveram aumento significativo nos níveis dos anticorpos dosados.

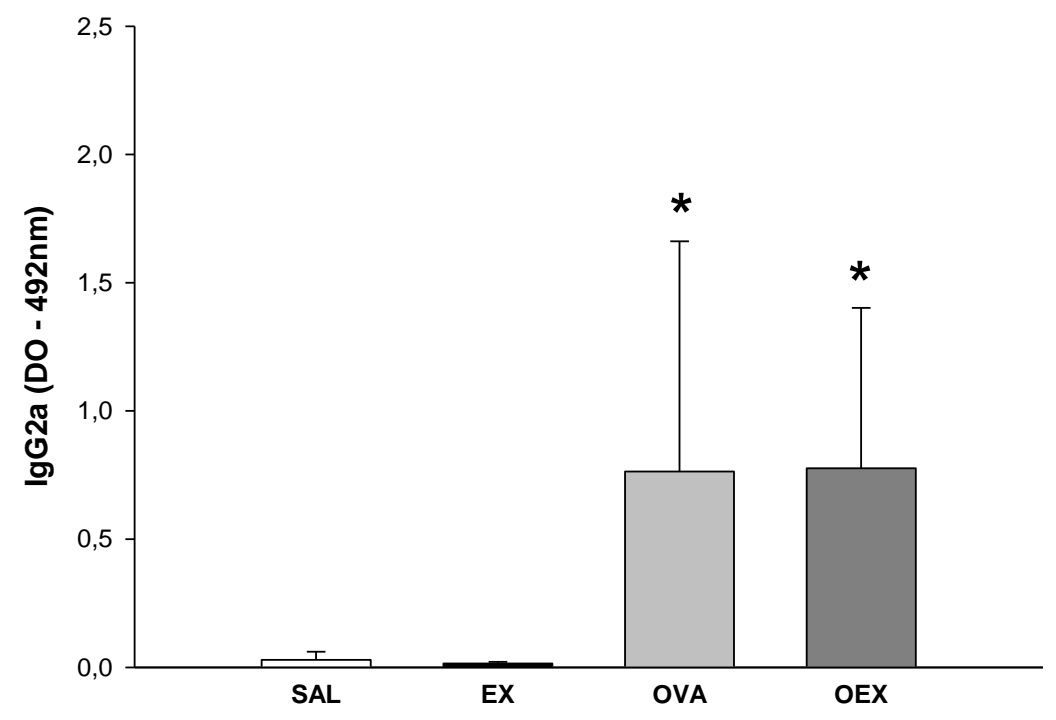

Figura 9 - A exposição antigênica associada à prática de exercício físico mantém elevado os níveis de IgG2a. Valores médios de absorbância ( \pm erropadrão) obtidos em ensaio imunoenzimático realizado com plasma de animais dos diversos grupos experimentais para a detecção de IgG2a anti-OVA. ${ }^{*} \mathrm{p}=0,047$ comparado ao grupo SAL. 


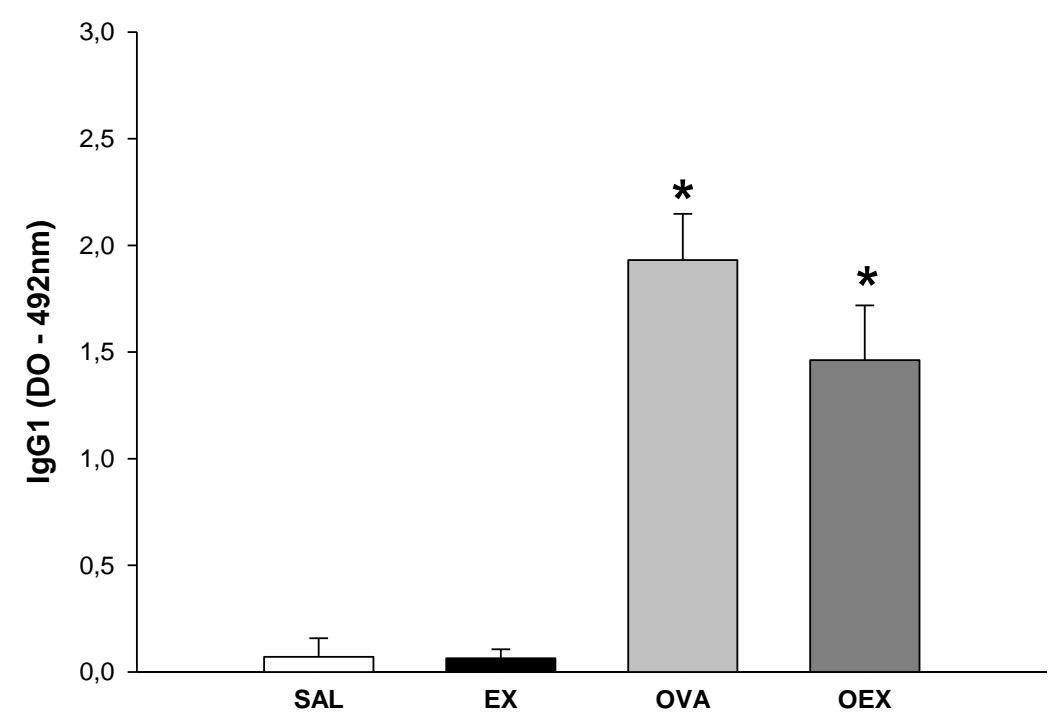

Figura 10- A exposição antigênica associada à prática de exercício físico mantém elevado os níveis de IgG1. Valores médios ( \pm erro-padrão) de absorbância obtidos em ensaio imunoenzimático realizado com plasma de animais dos diversos grupos experimentais para a detecção de IgG1 anti-OVA. ${ }^{*} \mathrm{p}<0,001$ comparados ao grupo SAL.

\subsection{Titulação de IgE por PCA}

Foi analisada a produção de anticorpos da classe lgE específicos antiOVA nos diferentes grupos experimentais através do método de PCA. A figura 12 mostra os resultados obtidos para este parâmetro e nota-se que os animais sensibilizados à OVA apresentaram títulos de IgE maiores que 1/160. A prática de atividade física não alterou a intensa produção de IgE. Já nos animais do grupo SAL e os animais não sensibilizados que praticaram atividade física (EX) não foram detectados títulos de lgE, conforme o esperado. 


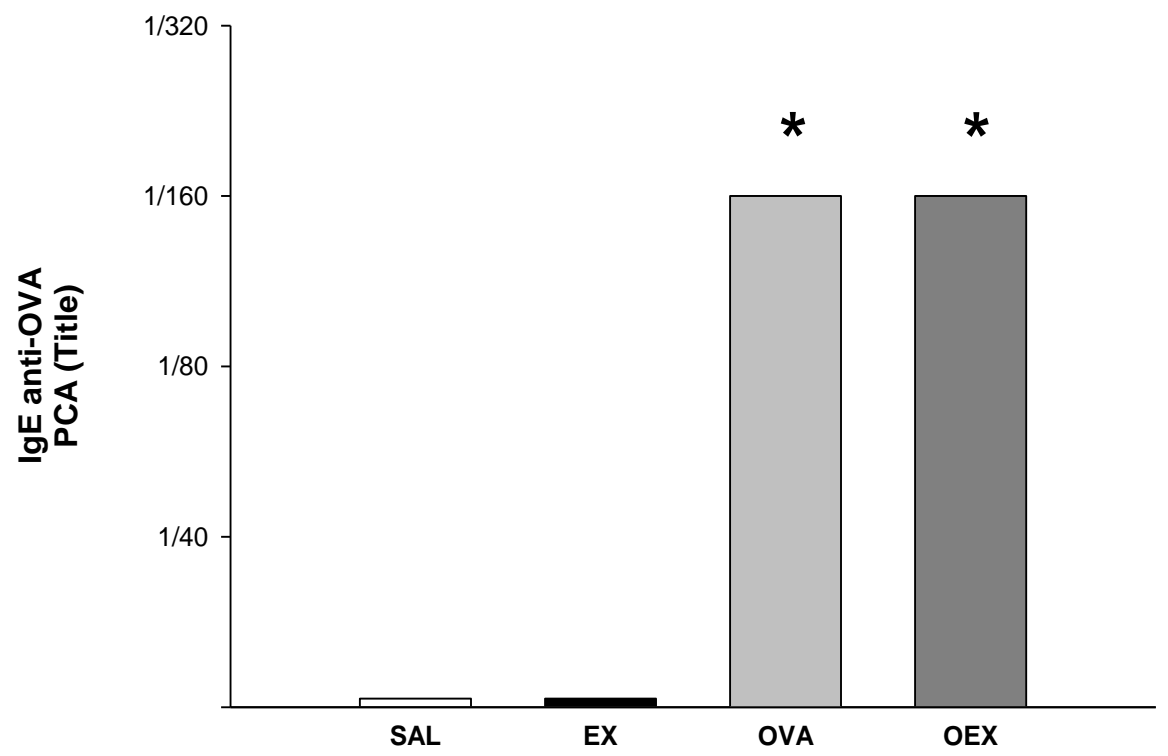

Figura 11 - A prática de exercício físico moderado mantém elevada a produção de IgE anti-OVA. Valores médios da avaliação da titulação em triplicata de anticorpos anafiláticos da classe lgE, pela técnica de PCA. * valores estatisticamente diferentes em relação ao grupo controle, SAL ou EX.

\subsection{Quantificação de citocinas por ELISA}

Realizamos o ensaio imunoenzimático (ELISA) para quantificação das citocinas IL-4, IL-6, TGF- $\beta$ e IL-10 a partir do homogenato pulmonar dos animais dos grupos experimentais. As figura 13A e B demonstram que a sensibilização a ovalbumina eleva os níveis de IL-4 e IL-6 o exercício físico reverte esta elevação, respectivamente. Além disso, nas figuras 13C e 13D podemos 
observar que a prática de exercício físico eleva os níveis de citocinas antiinflamatórias TGF- $\beta$ e IL-10.

A

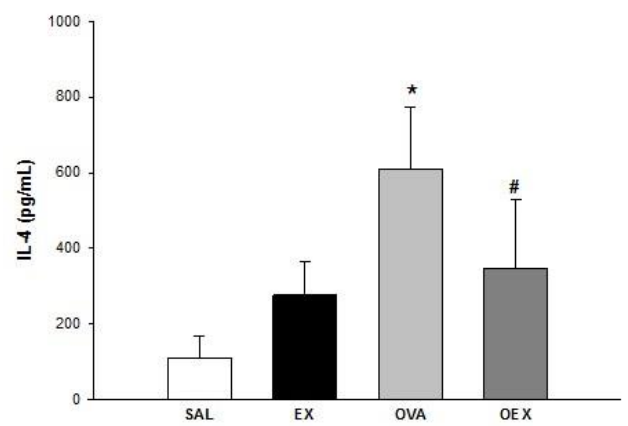

C

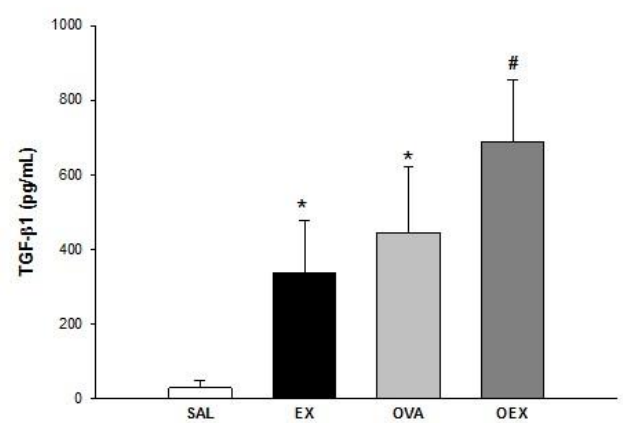

B

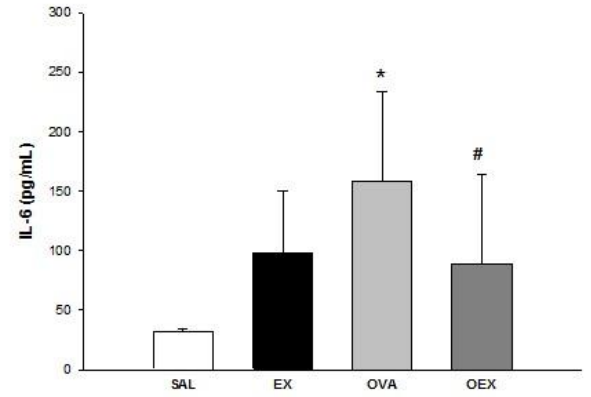

D

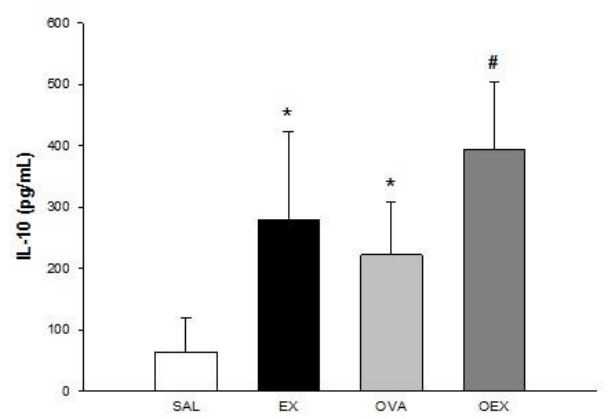

Figura 12 - Quantificação de citocinas presentes no tecido pulmonar. Valores médios ( \pm erro-padrão) obtidos no homogenato pulmonar. AQuantificação de IL-4, onde ${ }^{*} \mathrm{p}=0,008$ comparado o grupo SAL e \#p=0,035 comparado ao grupo OVA) B- IL-6 presente no tecido pulmonar, o qual * $\mathrm{p}=0,008$ comparado o grupo SAL e \#p=0,035 comparado ao grupo OVA. C e D- TGF- $\beta$ e $\mathrm{IL}-10,{ }^{*} \mathrm{p}=0,001$ comparado o grupo SAL e $\# \mathrm{p}=0,035$ comparado ao grupo OVA. 
4.7 Avaliação Fenotípica das Células Inflamatórias Presentes no Tecido Pulmonar

Buscamos quantificar, no tecido pulmonar, as células inflamatórias presentes, assim como avaliar seus níveis de ativação.

Notamos que a sensibilização a ovalbumina (grupo OVA) apresentou aumento no influxo pulmonar de eosinófilos (figura 13), o que foi reduzido com o exercício físico (OEX).

Com relação aos linfócitos pulmonares, observamos que animais sensibilizados e submetidos ao protocolo de treinamento físico (OEX) obtiveram aumento tanto do influxo (figura 14) como nos níveis de ativação de células T CD4+, com elevada expressão de CD69+ nos grupos sensibilizados a OVA e treinados (OEX) (figura 15). Neste mesmo sentido, ainda pudemos observar nos pulmões de animais do grupo OEX aumento do influxo pulmonar de linfócitos TCD8+ (figura 16) com maior ativação (figura 17). Nota-se, no grupo OEX um aumento significativo de células reguladoras T CD4+ CD25+ FOXP3+ (figura 18) no sítio da inflamação, pulmão, com aumento na expressão de LAP+, indicando a produção de TGF- $\beta$ (figura 19) e IL-10 (figura 20), mostrando que o exercício físico gera uma contra regulação local da inflamação induzida pelo alérgeno OVA.

Na avaliação dos macrófagos presentes no tecido pulmonar, pudemos observar que a sensibilização a ovalbumina e a prática de exercício físico elevou 
os níveis de macrófagos totais (figura 21), macrófagos M2 (figura 22) e macrófagos M1 (figura 23).

Também foram avaliadas células dendríticas nos pulmões dos animais dos grupos experimentais e verificamos que em animais sensibilizados e treinados não observamos diferenças quantitativas de células dendríticas convencionais (cDCs) nos pulmões dos animais dos grupos experimentais (figura 24). Embora, obtivemos um aumento do número de células dendríticas plasmocitóides ( $\mathrm{pDCs}$ ), o que foi observado em animais que somente foram submetidos ao protocolo de treinamento (figura 25). 


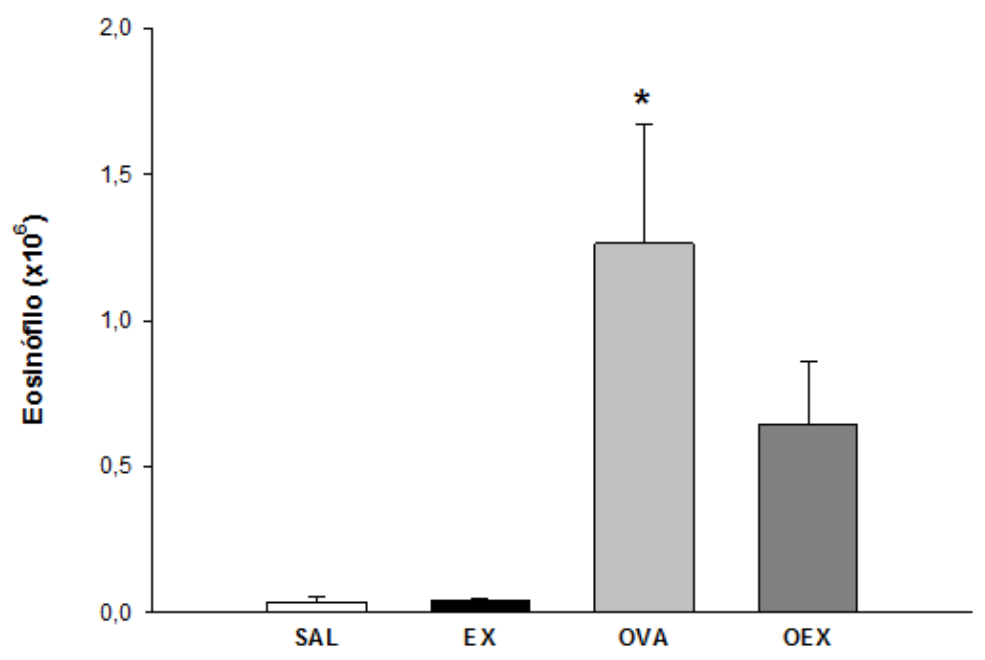

Figura 13 - Exercício físico protege o pulmão da intensa eosinofilia induzida pela sensibilização a OVA. Valores médios de eosinófilos ( \pm erropadrão) obtidos no tecido pulmonar. $\mathrm{P}<0,001$ comparado ao grupo $\mathrm{SAL}$.

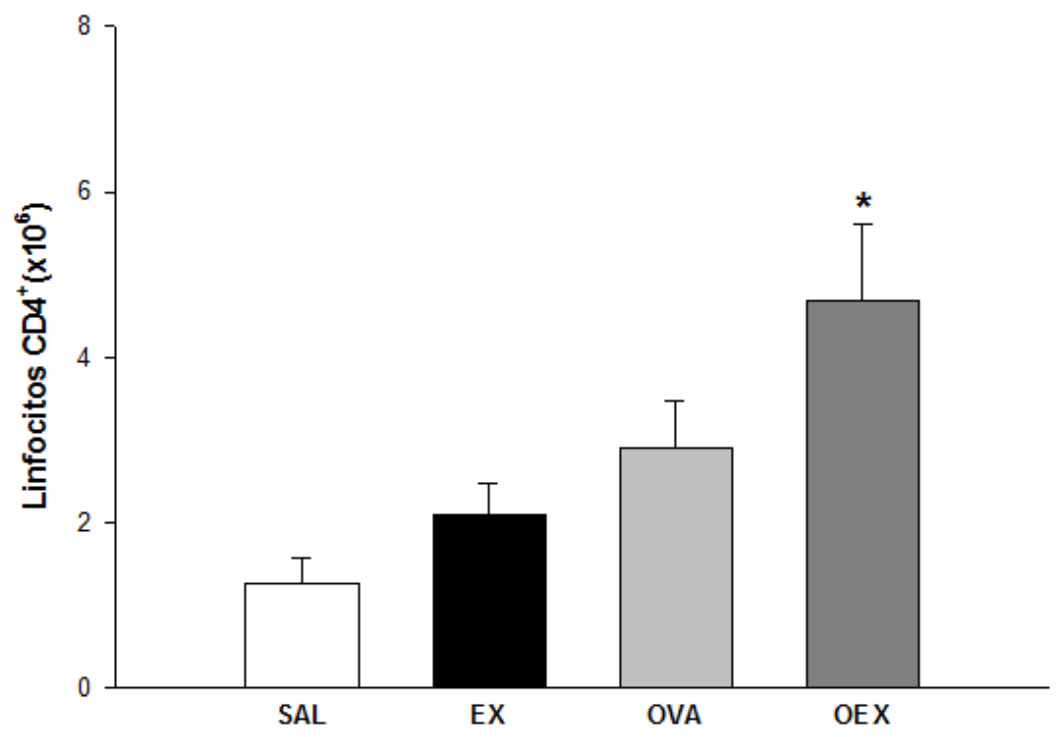

Figura 14 - 0 exercício físico eleva o influxo de linfócitos CD4+ no pulmão de animais sensibilizados. Valores médios de linfócitos CD4+ ( \pm erro-padrão) obtidos no tecido pulmonar. ${ }^{*} \mathrm{p}=0,010$ comparado ao grupo SAL. 


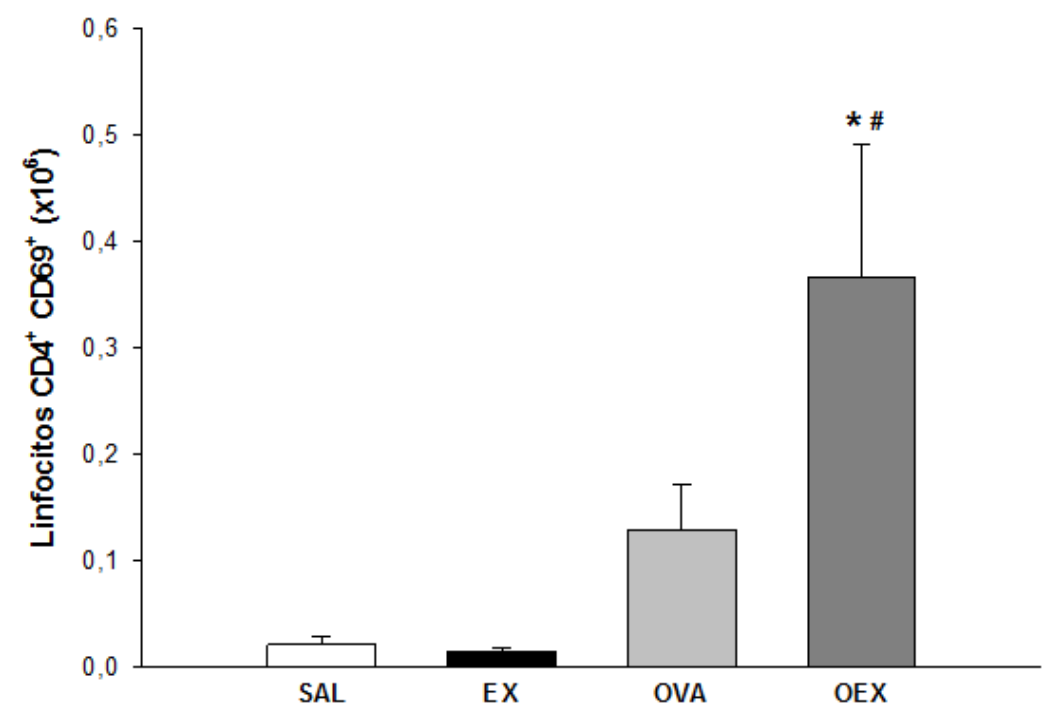

Figura 15 - 0 exercício físico induz intensa ativação dos linfócitos CD4+ pulmonares de animais alérgicos. Valores médios de ativação dos linfócitos CD4+ pela expressão de CD69 ( \pm erro-padrão) obtidos no tecido pulmonar. ${ }^{*} \mathrm{p}=0,006$ comparado ao EX e \#p<0,001 se comparado ao OVA.

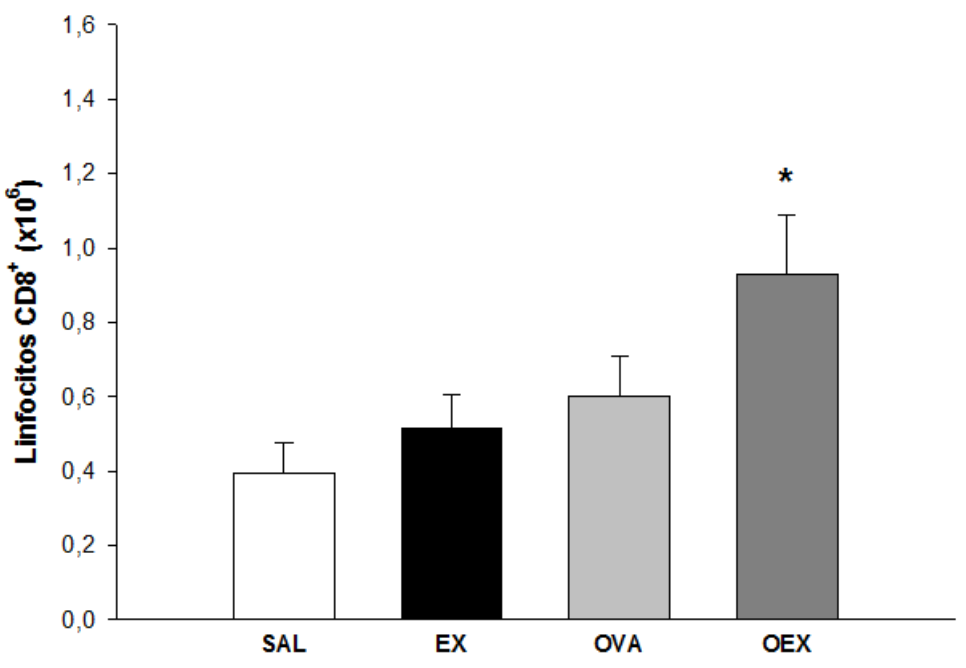

Figura 16 - 0 exercício físico eleva o influxo pulmonar de linfócitos T CD8+ em animais alérgicos. Valores médios de linfócitos T CD8+ ( \pm erro-padrão) obtidos no tecido pulmonar. ${ }^{*} \mathrm{p}=0,026$ se comparado ao grupo EX. 


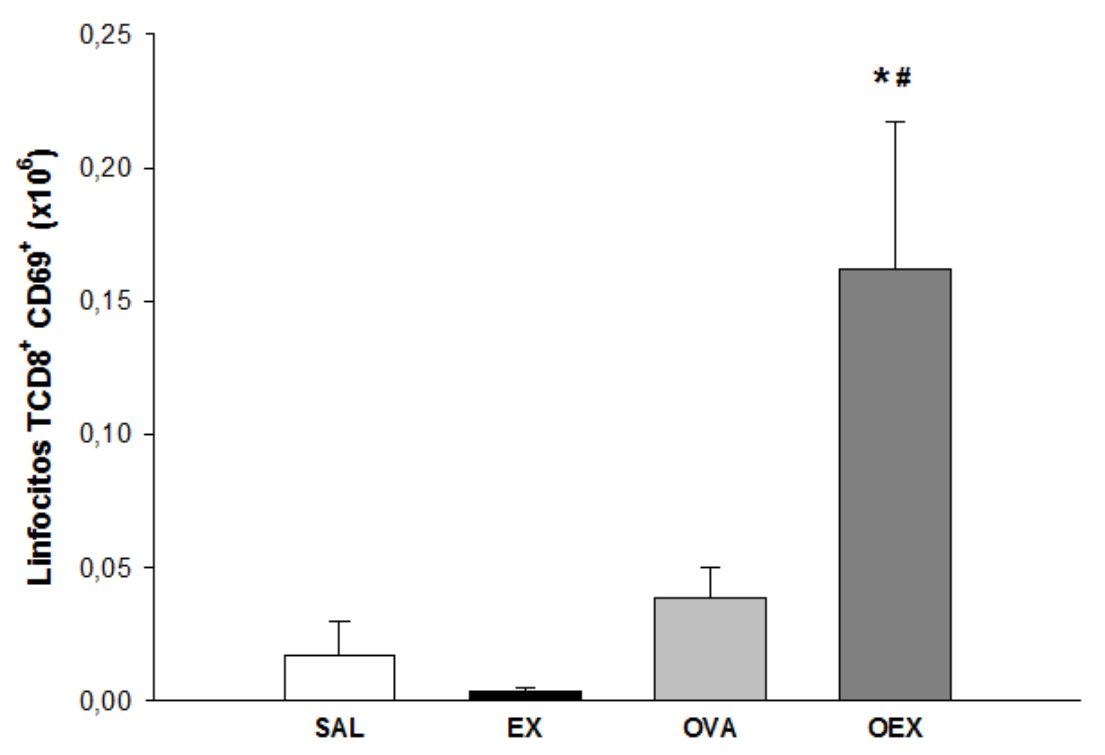

Figura 17 - 0 exercício físico eleva a ativação nos linfócitos T CD8+ pulmonares em animais alérgicos. Valores médios de TCD8+ CD69+ ( \pm erropadrão) obtidas no tecido pulmonar. ${ }^{*} p<0,001$ se comparado ao grupo EX e $\# p=0,004$ comparado ao grupo OVA.

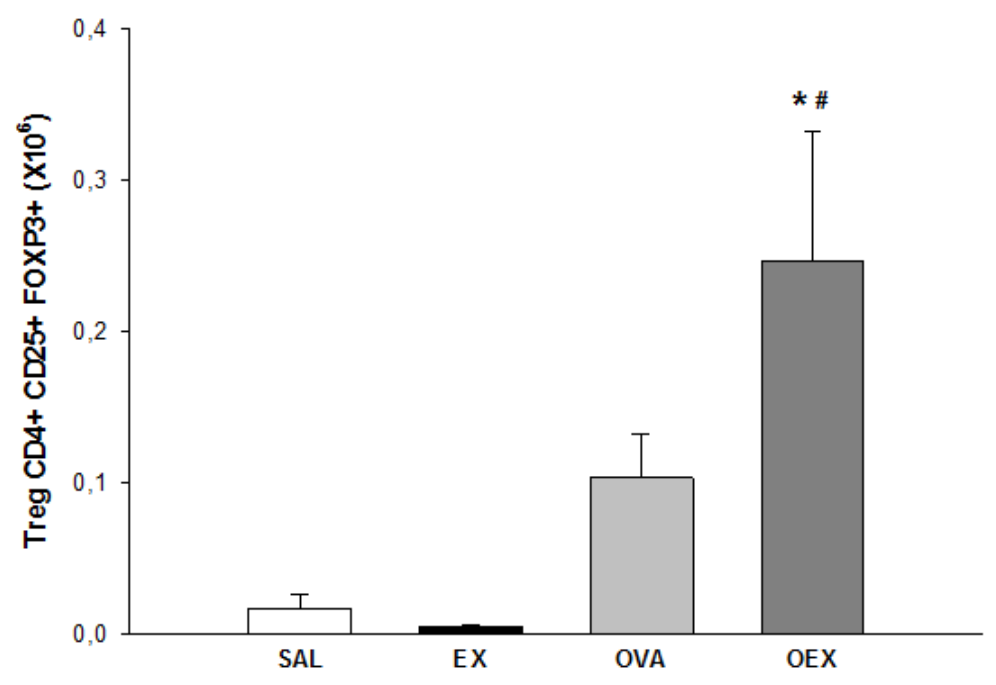

Figura 18 - 0 exercício físico regula a inflamação induzida pela OVA com maior influxo pulmonar de Treg. Valores médios de Tregs ( \pm erro-padrão) obtidas no tecido pulmonar. ${ }^{*} p<0,001$ se comparado ao grupo $E X$ e $\# p=0,032$ se comparado ao grupo OVA. 


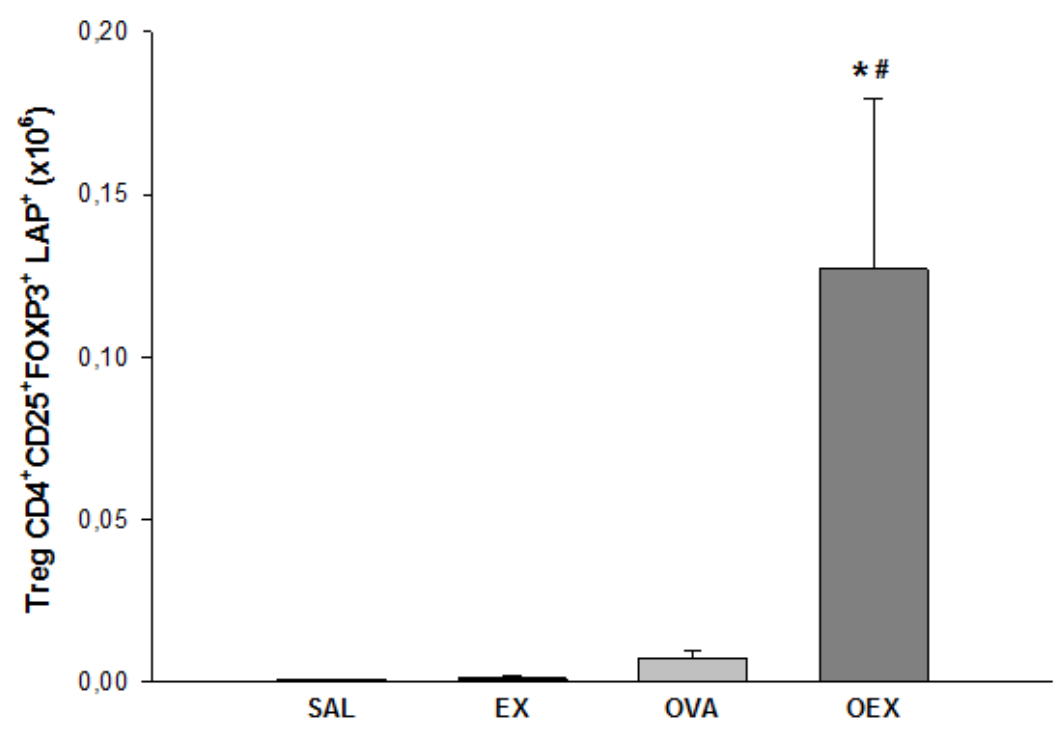

Figura 19 - 0 exercício físico induz maior produção de TGF- $\beta$ em Tregs pulmonares de animais alérgicos. Valores médios da expressão de TGF- $\beta$ ( \pm erro-padrão) em Tregs obtidas no tecido pulmonar. ${ }^{*} \# p<0,001$ se comparado ao grupo EX ou ao grupo OVA.

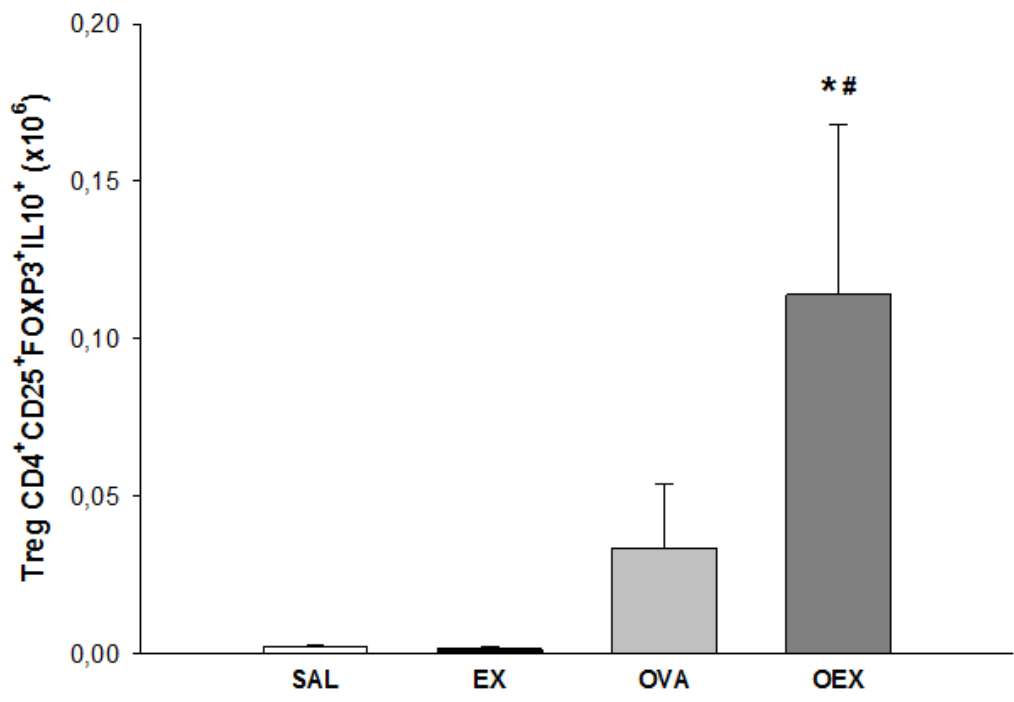

Figura 20 - 0 exercício físico amplifica a produção de IL-10 em Tregs pulmonares de animais alérgicos. Valores médios da expressão de IL-10 em Tregs ( \pm erro-padrão) obtidas no tecido pulmonar. ${ }^{*} p=0,011$ se comparado ao EX e \#p=0,049 ao OVA. 


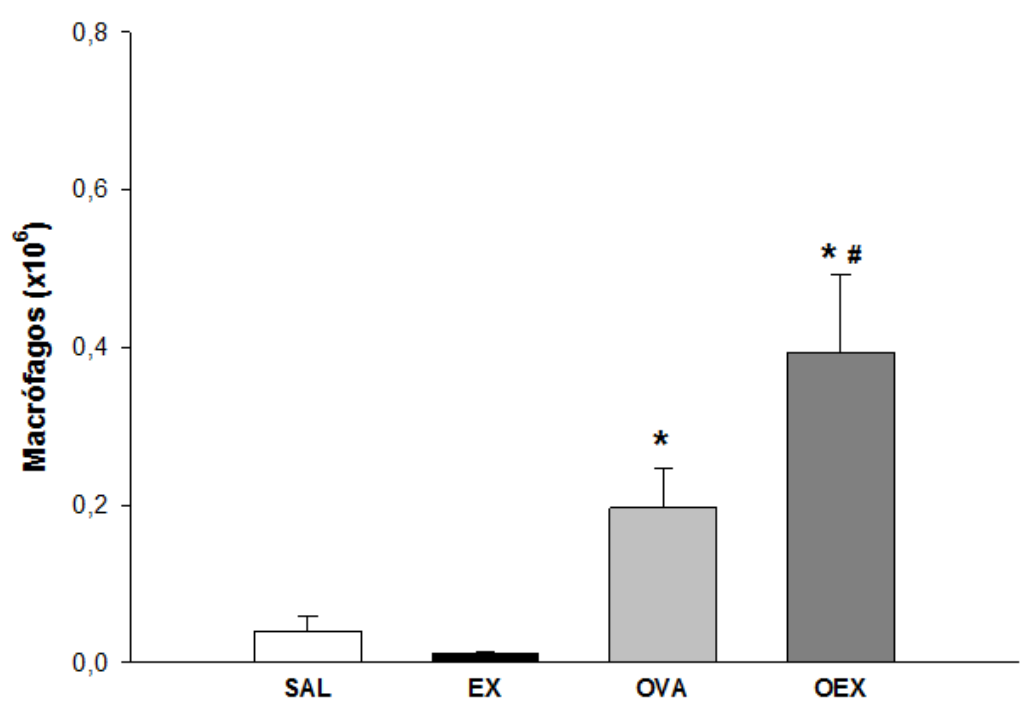

Figura 21 - 0 exercício exacerba o influxo de macrófagos pulmonares em animais alérgicos. Valores médios de macrófagos ( \pm erro-padrão) obtidos no tecido pulmonar. ${ }^{*} \mathrm{p}=0,043$ comparado ao grupo $\mathrm{SAL}$ e $<0,001$ se comparado ao grupo $\mathrm{EX} ; \mathrm{p}=0,048$ comparado ao grupo OVA.

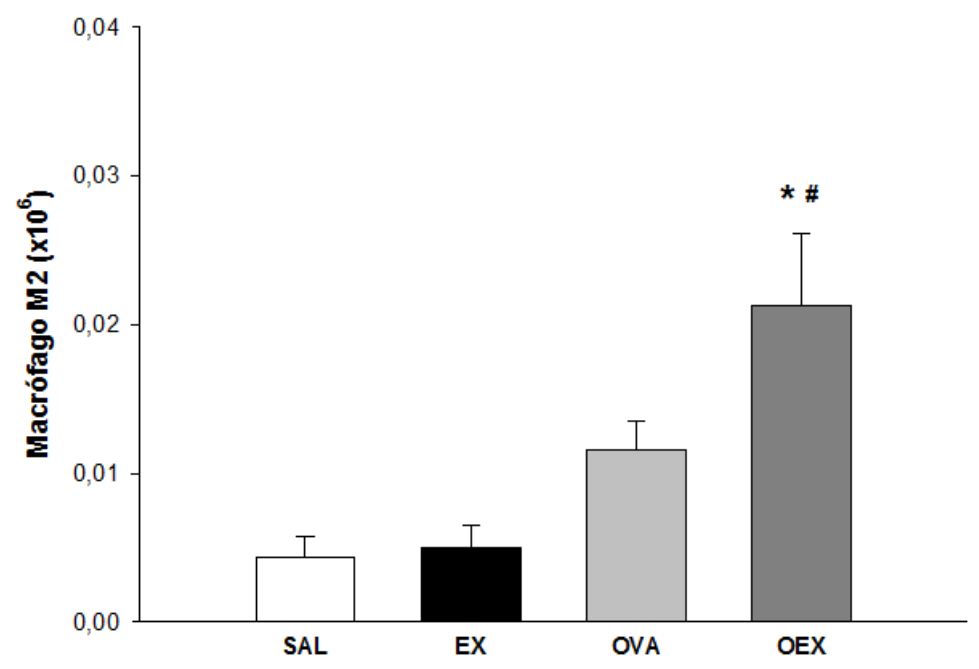

Figura 22 - Comportamento semelhante pode ser observado nos macrófagos pulmonares M2 de animais alérgicos praticantes de exercício físico Valores médios de macrófagos M2 ( \pm erro-padrão) obtidos no tecido pulmonar. ${ }^{*} \mathrm{p}=0,001$ se comparado ao grupo $\mathrm{EX}$ e $\# \mathrm{p}=0,030$ quando comparado ao grupo OVA. 


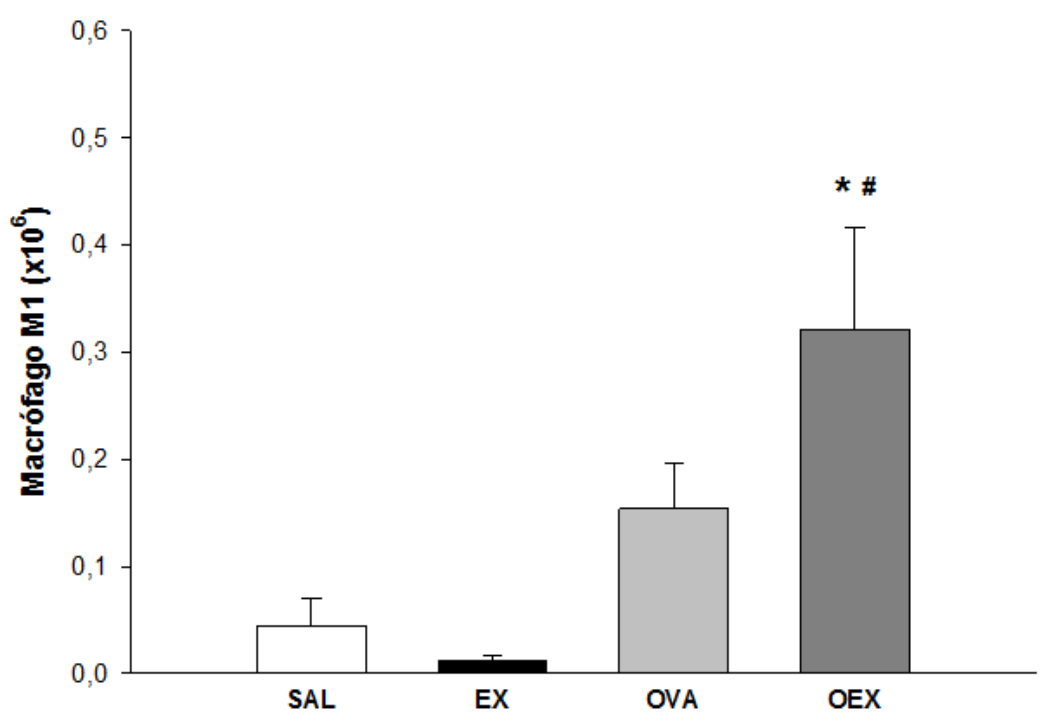

Figura 23 - 0 exercício físico eleva o número de macrófagos pulmonares M1 de animais alérgicos. Valores médios de macrófagos M1 ( \pm erro-padrão) obtidos no tecido pulmonar. ${ }^{*} p=0,036$ se comparado ao grupo $E X$ e $\# p=0,020$ quando comparado ao grupo OVA.

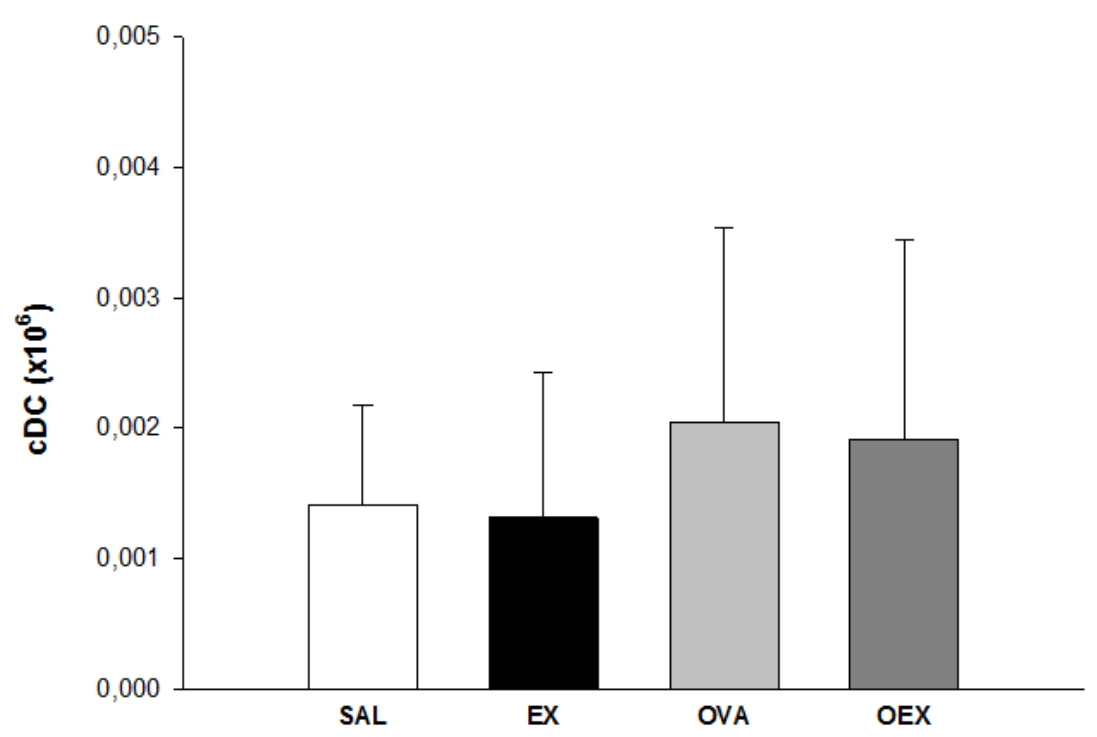

Figura 24 - A sensibilização a ovalbumina associada ao treinamento físico não altera níveis de cDCs. Valores médios de cDCs ( \pm erro-padrão) obtidos no tecido pulmonar. 


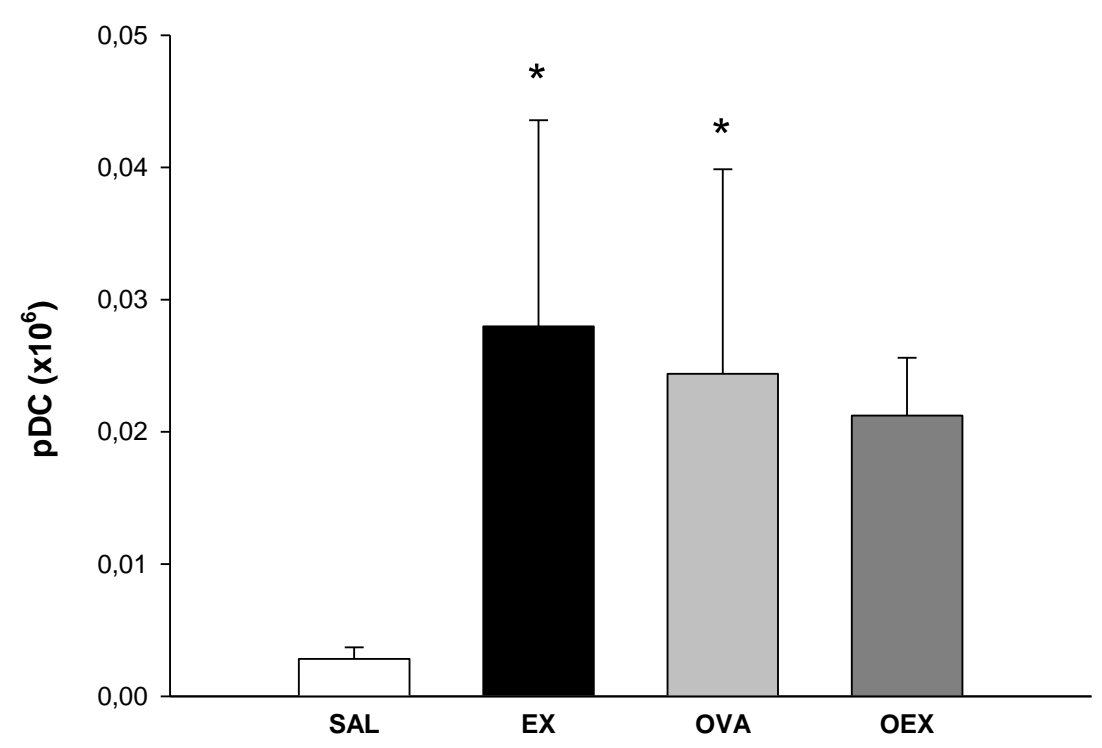

Figura 25 - 0 exercício físico e a sensibilização a ovalbumina elevam o número de células dendríticas plasmocitóides (pDCs) sem haver sinergia entre ambos os fatores. Valores médios de pDC ( \pm erro-padrão) obtidos no tecido pulmonar. ${ }^{*} p<0,006$ se comparado ao grupo SAL.

\subsection{Avaliação Fenotípica das Células Inflamátórias Presentes no}

\section{Tecido Linfóide}

Assim como no pulmão, buscamos quantificar nos linfonodos mediastinais as células inflamatórias presentes e avaliar os níveis de ativação celular.

$\mathrm{Na}$ figura 26 observamos que animais sensibilizados apresentaram aumento significativo do número de linfócitos TCD4+ presentes nos linfonodos mediastinais. Interessantemente, observamos que os linfócitos TCD4+ no grupo treinado apresentam maior ativação destes linfócitos (figura 27). 
$\mathrm{Na}$ avaliação dos macrófagos presentes nos linfonodos, pudemos observar que a sensibilização à ovalbumina por si só aumentou o número de macrófagos M2 e a prática de exercício físico associada à sensibilização foi capaz de reduzir esses níveis (figura 34), não alterando a quantidade de macrófagos M1 (figura 35).

Avaliando as células dendríticas presentes nos linfonodos dos animais dos grupos experimentais, verificamos que cDCs de animais sensibilizados apresentaram aumento da expressão de moléculas co-estimulatórias CD80, CD86 e ICOSL, demonstrando um perfil pró-inflamatório e o exercício por sua vez, reduz essa expressão (figura 36). Além disso, houve um aumento significativo de pDCs no grupo OVA. Também houve o aumento da expressão de moléculas CD80 nas pDCs presentes nos linfonodos dos animais asmáticos, mostrando maior ativação celular, entretanto, no grupo OEX houve redução dessa ativação, além de apresentar elevação na expressão de moléculas ICOSL, demostrando claramente um perfil anti-inflamatório nestas células (figura 37). 


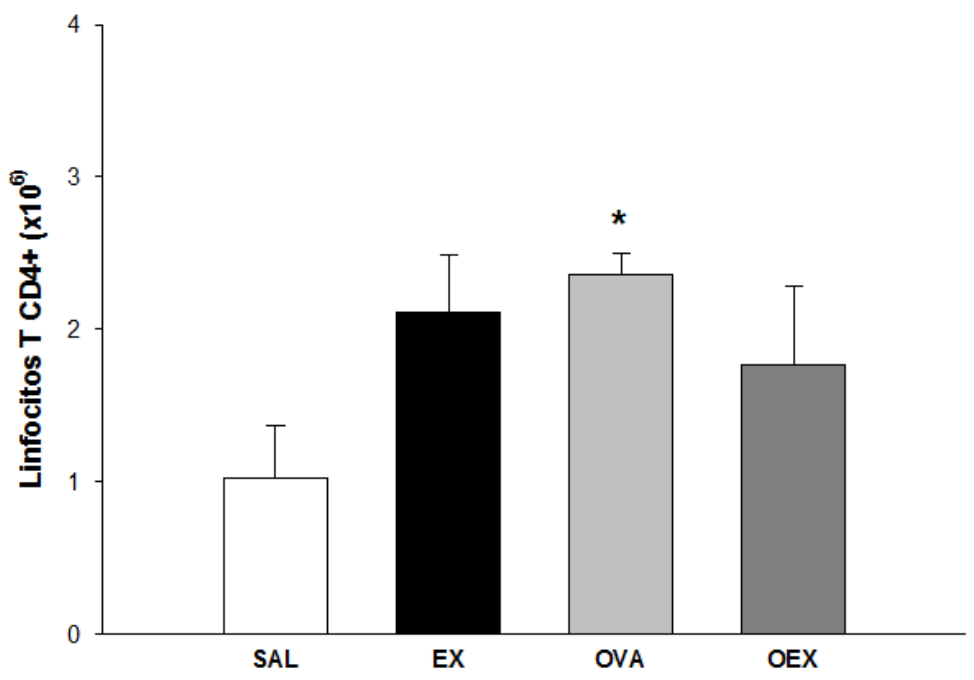

Figura 26 - 0 exercício físico não altera o elevado número de linfócitos $T$ CD4+ presentes nos linfonodos drenantes. Valores médios de linfócitos $T$ CD4+ ( \pm erro-padrão) obtidos no tecido linfóide. ${ }^{*} p=0,036$ se comparado ao grupo SAL.

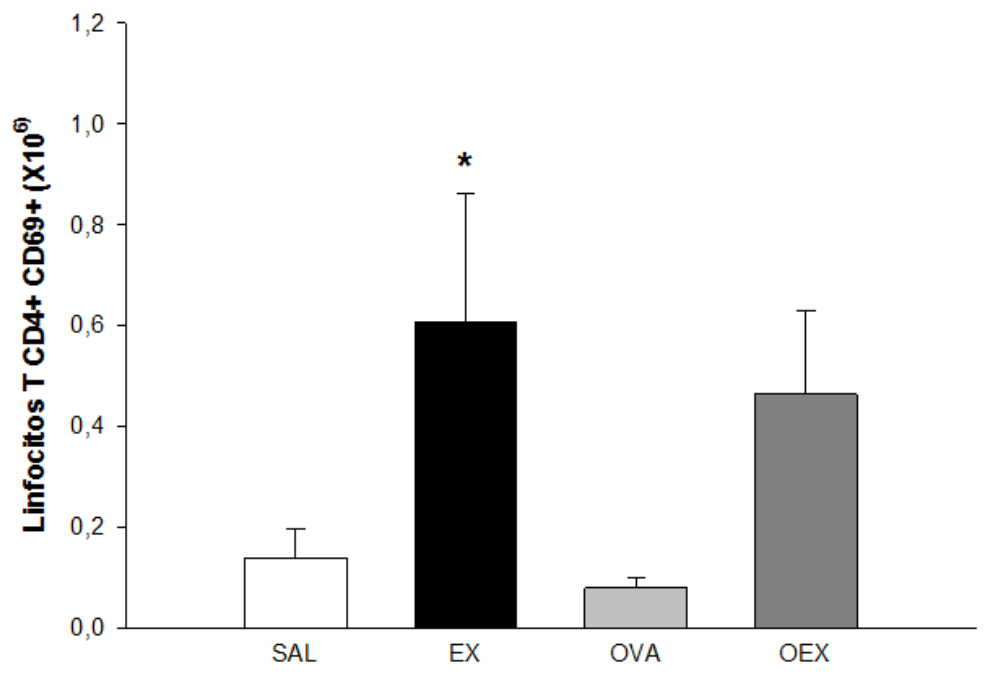

Figura 27 - 0 exercício físico eleva a ativação dos linfócitos T CD4+ presentes nos linfonodos drenantes. Valores médios de linfócitos T CD4+ $( \pm$ erro-padrão) obtidos no tecido linfóide. ${ }^{*} \mathrm{p}=0,036$ se comparado ao grupo SAL. 


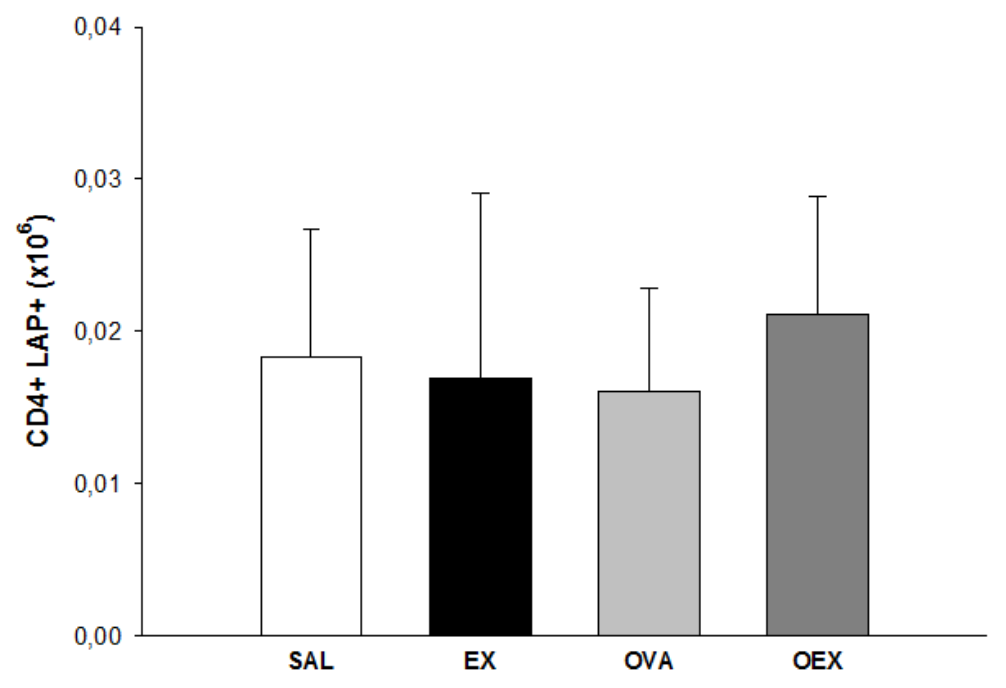

Figura 28 - 0 exercício físico não altera a liberação de TGF- $\beta$ nos linfócitos T CD4+ presentes nos linfonodos drenantes. Valores médios de expressão de TGF- $\beta$ ( \pm erro-padrão) obtidos no tecido linfóide.

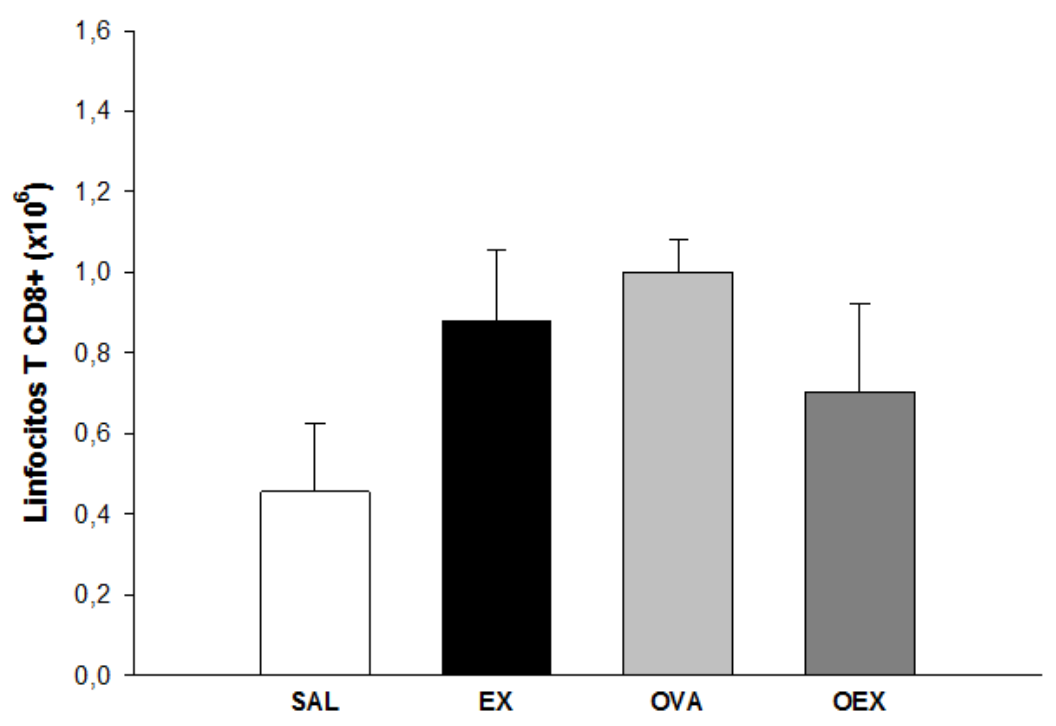

Figura 29 - 0 exercício físico não altera o número de linfócitos T CD8+ presentes nos linfonodos drenantes. Valores médios de linfócitos T CD8+ $( \pm$ erro-padrão) obtidos no tecido linfóide. 


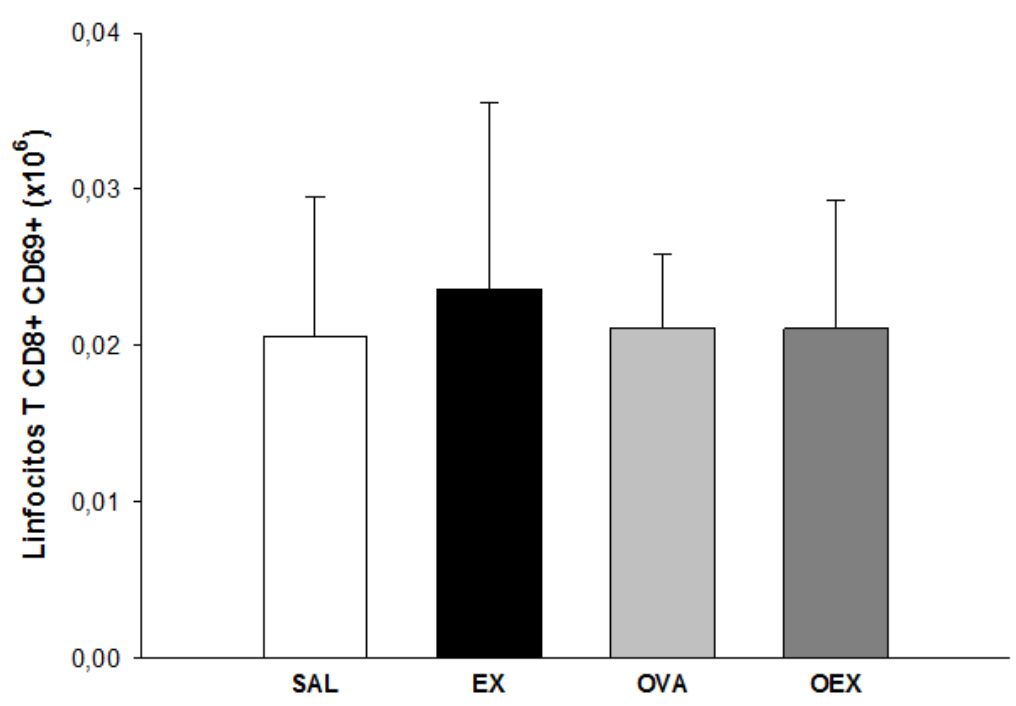

Figura 30 - 0 exercício físico também não altera a ativação dos linfócitos $T$ CD8+ presentes nos linfonodos drenantes. Valores médios de da expressão de CD69 nos linfócitos T CD8+ ( \pm erro-padrão) obtidos no tecido linfóide.

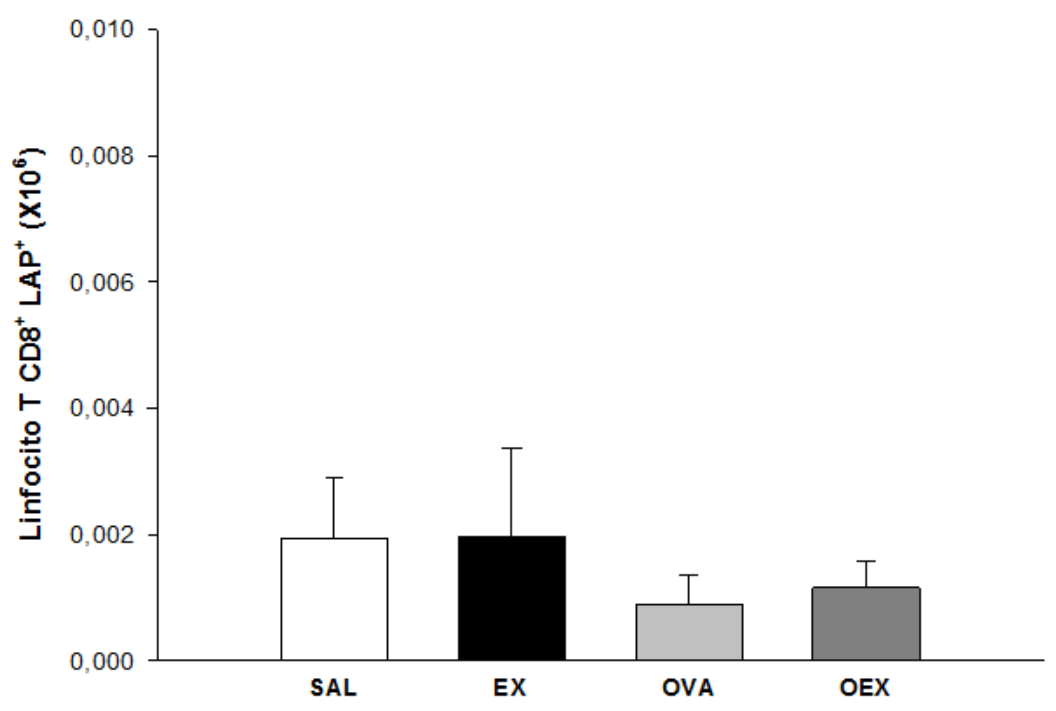

Figura 31 - 0 exercício físico não altera a liberação de TGF- $\beta$ nos linfócitos T CD8+ presentes nos linfonodos drenantes. Valores médios da expressão de LAP em linfócitos T CD8+ ( \pm erro-padrão) obtidos no tecido linfóide. 


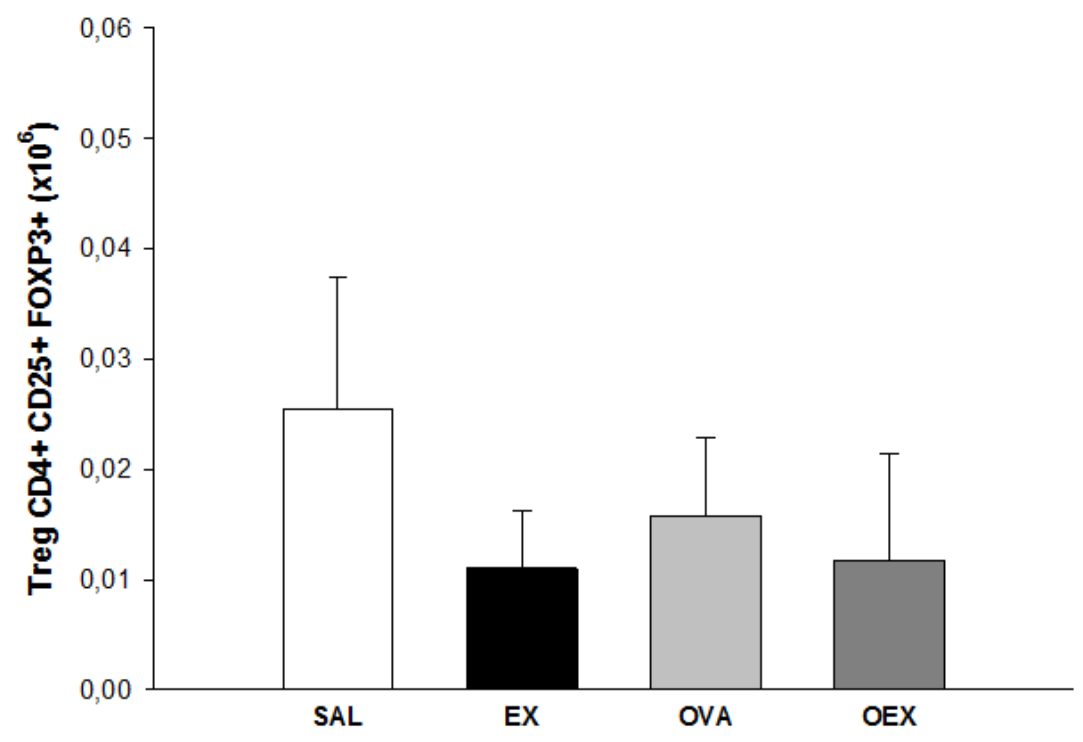

Figura 32 - 0 exercício físico não altera o número de Tregs presentes nos linfonodos drenantes. Valores médios de Tregs ( \pm erro-padrão) obtidos no tecido linfóide.

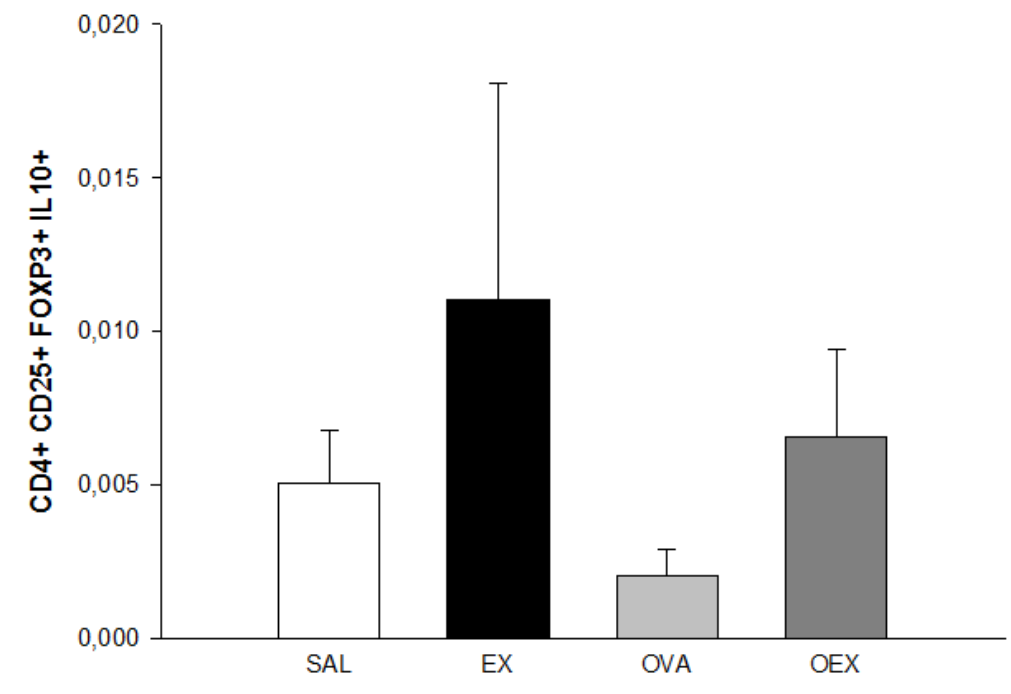

Figura 33 - O exercício físico não altera a produção de IL-10 nos Tregs presentes nos linfonodos drenantes. Valores médios na produção de IL-10 nos Tregs ( \pm erro-padrão) obtidos no tecido linfóide. 


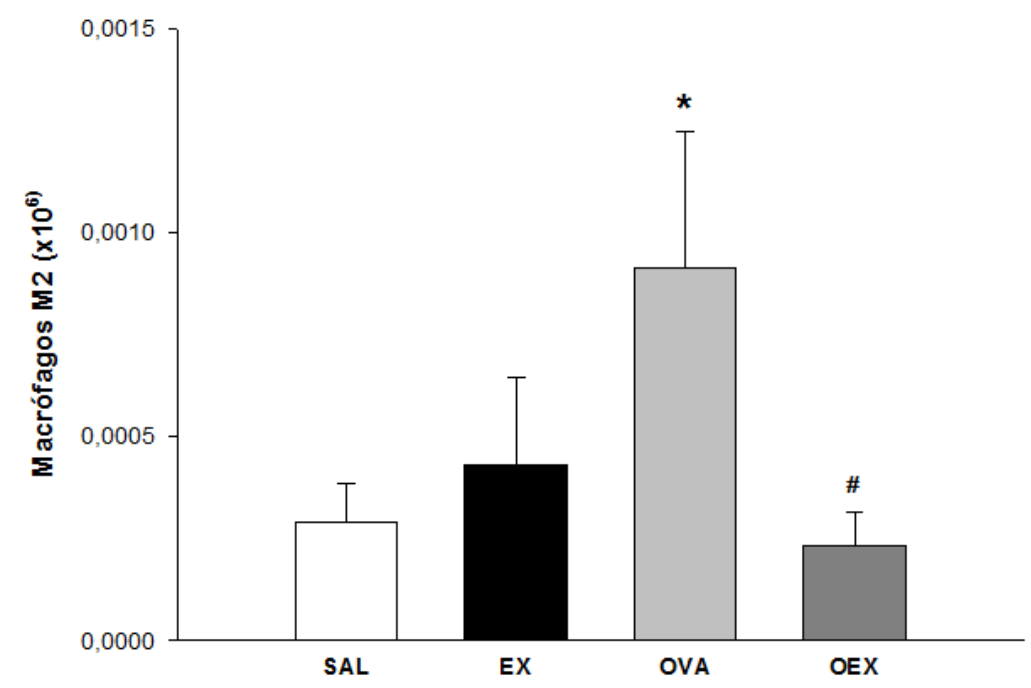

Figura 34 - O exercício físico reduz a migração de macrófagos M2 aos linfonodos drenantes em animais alérgicos. Valores médios de macrófagos M2 ( \pm erro-padrão) obtidos no tecido linfóide. ${ }^{*} \mathrm{p}=0,036$ se comparado ao grupo EX e \#p=0,020 quando comparado ao grupo OVA.

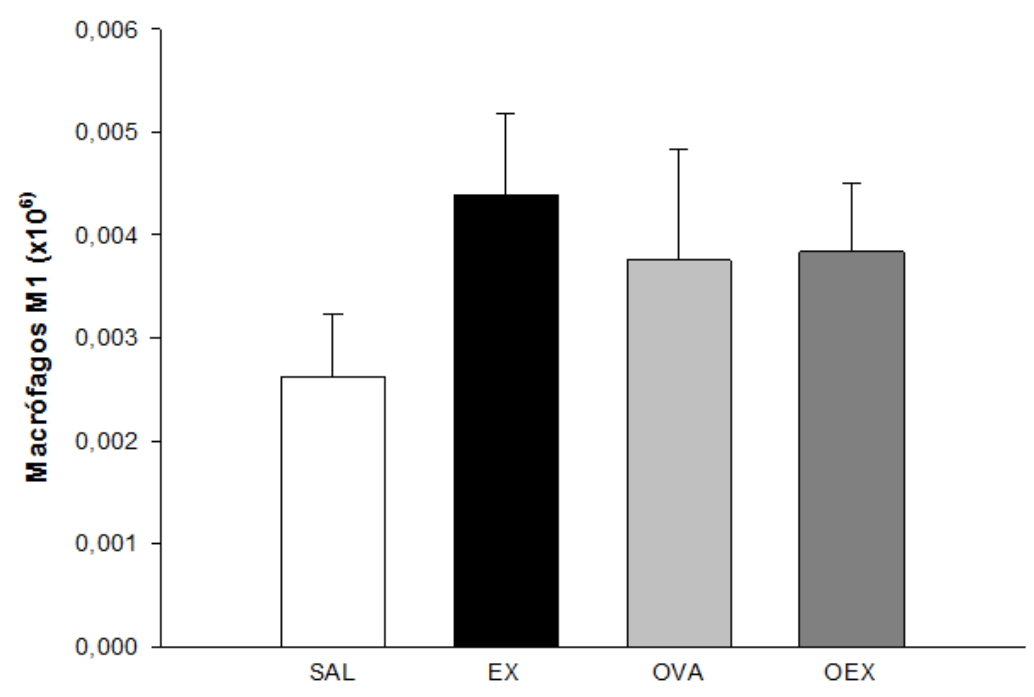

Figura 35 - 0 exercício físico não altera a migração de macrófagos M1 aos linfonodos drenantes. Valores médios de macrófagos M1 ( \pm erro-padrão) obtidos no tecido linfóide. 

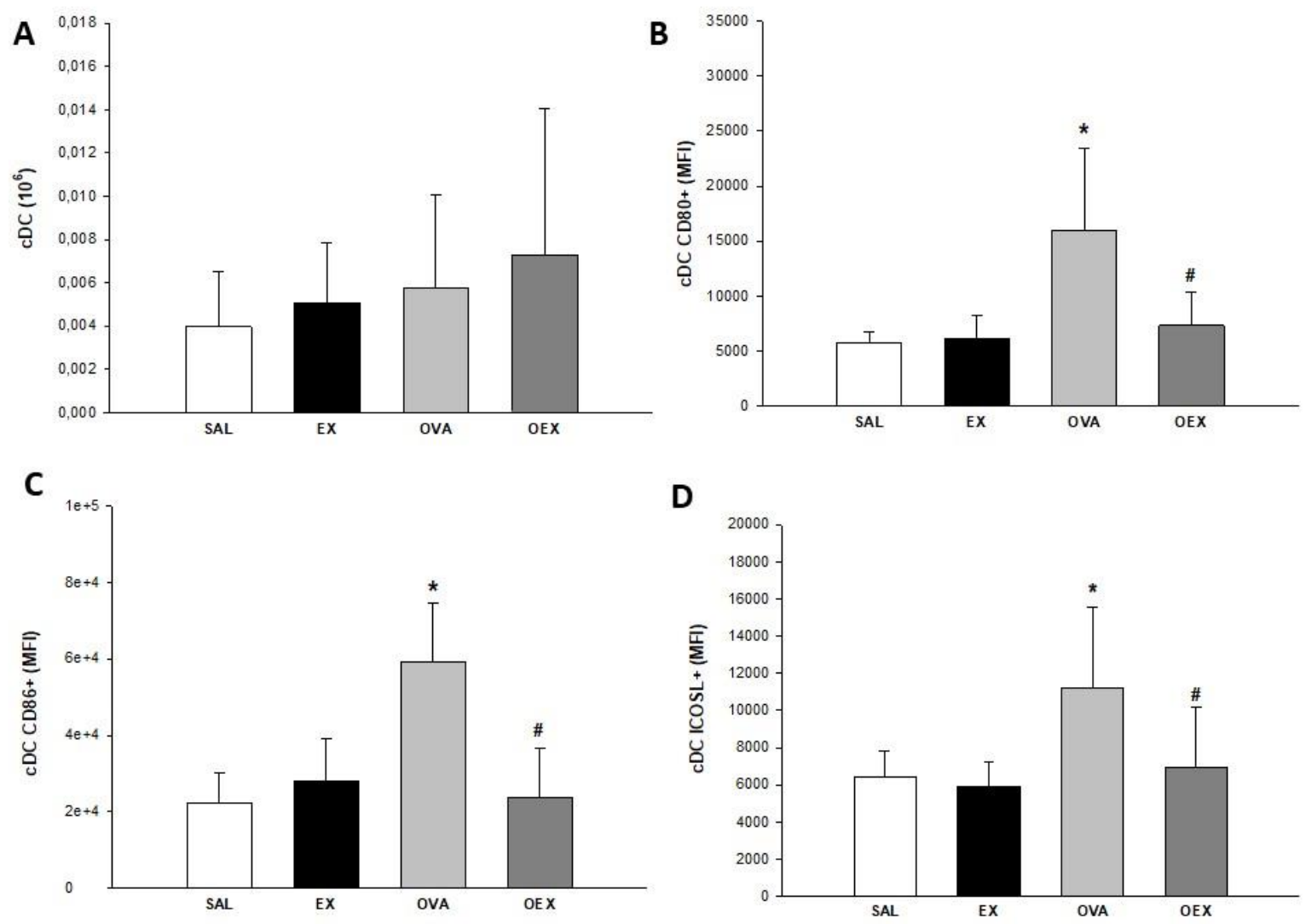

Figura 36- $O$ exercício físico reduz a ativação induzida pela OVA em cDCs no tecido linfoide. A- Quantificação de CDCs no tecido linfoide. Valores médios de cDCs ( \pm erro-padrão) obtidos no tecido linfóide. B- A sensibilização a ovalbumina eleva a expressão de $\mathrm{CD} 80+$ em células dendríticas plasmocitóides (pDCs) e o exercício físico reduz essa mesma expressão. Valores médios de cDCs CD80+ ( \pm erro-padrão) obtidos no tecido linfoide, ${ }^{*} p<0,001$ se comparado ao grupo $S A L, \# p=0,001$ se compado ao grupo OVA. CA sensibilização a ovalbumina eleva a expressão de CD86+ em células dendríticas convencionais (cDCs) e o exercício físico reduz essa mesma expressão. Valores médios de cDCs CD86+ ( \pm erro-padrão) obtidos no tecido linfoide, ${ }^{*} p<0,001$ se comparado ao grupo $S A L$, \#p=0,001 se compado ao grupo OVA. D- A sensibilização a ovalbumina eleva a expressão de ICOSL+ em células dendríticas convencionais (cDCs) e o exercício físico reduz essa mesma expressão. Valores médios de CDCs ICOSL+ ( \pm erro-padrão) obtidos no tecido linfoide, ${ }^{*} \mathrm{p}<0,007$ se comparado ao grupo $\mathrm{SAL}$, $\# \mathrm{p}=0,012$ se compado ao grupo OVA. 

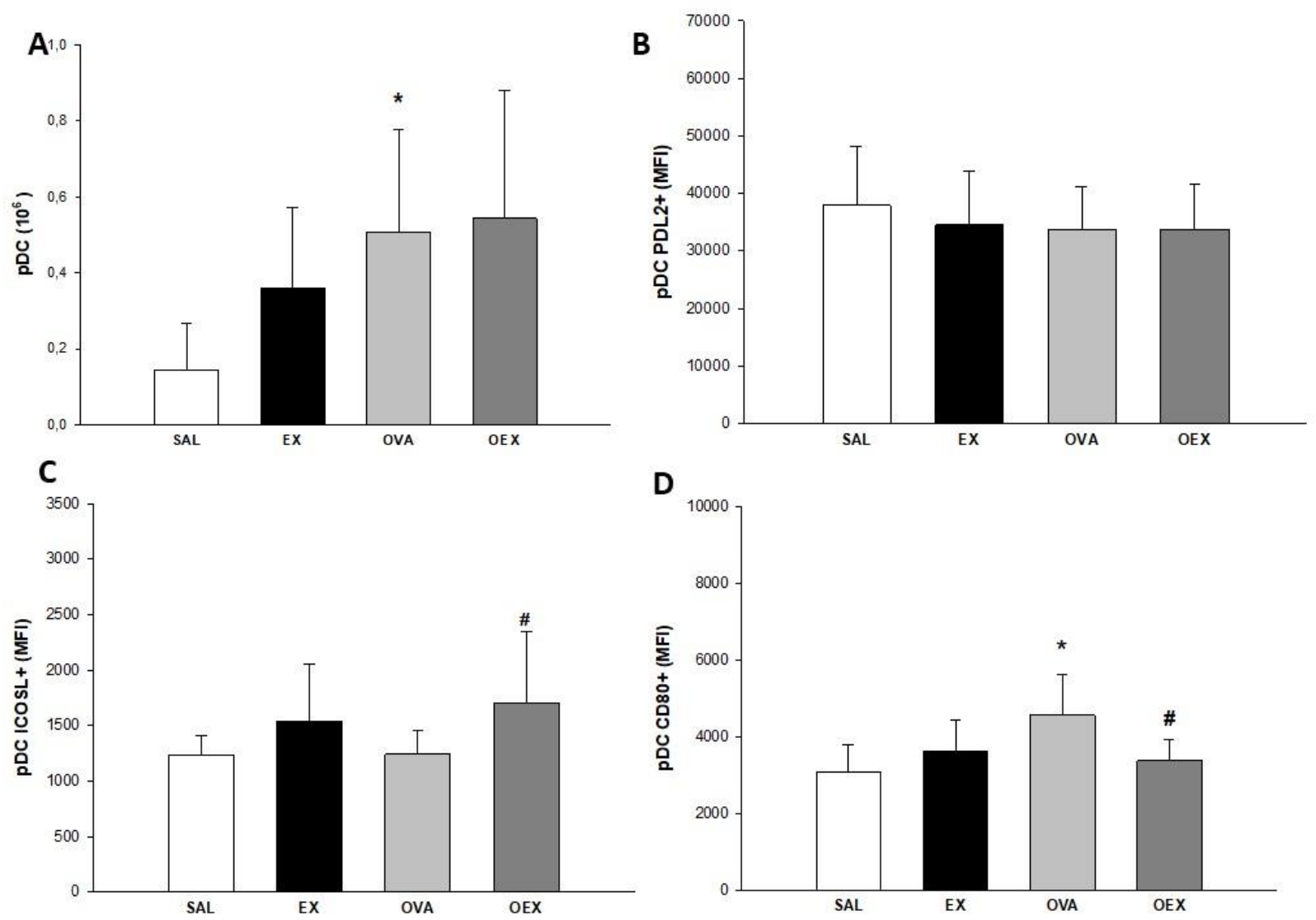

Figura 37 - Quantificação de pDCs no tecido linfoide. A- A sensibilização a ovalbumina eleva os números de células dendríticas plasmocitóides. Valores médios de pDCs ( \pm erro-padrão) obtidos no tecido linfoide, ${ }^{*} \mathrm{p}=0,024$ se comparado ao grupo SAL. B- Níveis de expressão de PDL2 em pDCs. Valores médios de pDCs PDL2+ ( \pm erro-padrão) obtidos no tecido linfoide. C- A sensibilização a ovalbumina associada ao exercício físico eleva a expressão de ICOSL+ em pDCs. Valores médios de pDCs ICOSL+ ( \pm erropadrão) obtidos no tecido linfoide, $\# p=0,029$ se compado ao grupo OVA. D- A sensibilização a ovalbumina eleva a expressão de CD80+ em pDCs e o exercício físico reduz essa mesma expressão. Valores médios de pDCs CD80+ ( \pm erro-padrão) obtidos no tecido linfoide, ${ }^{*} p<0,005$ se comparado ao grupo $\mathrm{SAL}, \# \mathrm{p}=0,021$ se compado ao grupo OVA. 


\section{DISCUSSÃO}

No presente estudo, utilizamos o modelo de inflamação pulmonar alérgica crônica induzida pelo antígeno ovalbumina (OVA) associado ao treinamento aeróbico moderado em esteira ergométrica (protocolo experimental adaptado de Vieira et al, 2007). Visando avaliar a função pulmonar, realizamos testes de responsividade pulmonar ao agonista broncoconstritor metacolina. Como o esperado, animais sensibilizados ao antígeno OVA apresentaram hiperresponsividade pulmonar e interessantemente, a responsividade pulmonar de animais que praticaram exercício físico tende a reduzir quando comparada ao grupo sensibilizado. Sabemos que a inflamação crônica presente na asma está diretamente relacionada com a hiperresponsividade de vias aéreas, o que desencadeia os sinais e sintomas mais conhecidos da doença como o chiado, falta de ar, aperto no peito e tosse (Reddel, Pedersen, 2018). Estudos com modelos animais já mostraram que a sensibilização e desafio inalatório com diferentes proteínas, com ou sem adjuvantes leva ao aumento da hiperresponsividade brônquica (Kim, et, 2013). Outro estudo experimental, usando protocolo semelhante ao nosso, mostrou a redução na responsividade pulmonar em animais sensibilizados e treinados, embora tenha utilizado de metodologia mais sensível para detecção da hiperresponsividade de vias aéreas quando comparada a metodologia empregada no nosso trabalho (Silva, et al, 2010). 
Um fator importante, juntamente com a inflamação brônquica, que contribui para a elevação da responsividade pulmonar é o remodelamento de vias aéreas, definido pela presença de mudanças estruturais nas vias aéreas com hiperplasia e hipertrofia da musculatura lisa e das células globet, seguida de excessiva secreção de muco (Silva, et al, 2009). No nosso modelo experimental, animais sensibilizados à ovalbumina apresentaram hiperplasia/hipertrofia epitelial, além de aumento da produção de mucosubstâncias intraepiteliais, sendo que, o exercício físico associado à sensibilização ao antígeno reduz significantemente essa hipertrofia/hiperplasia e a quantidade de muco intraepitelial; indicando um papel protetor do exercício físico. Esses mesmos achados também foram observados por Silva, et al (2009), onde o treinamento aeróbico modulou a inflamação alérgica das vias aéreas, reduzindo o muco intraepitelial em animais que foram sensibilizados.

Além das alterações estruturais e de função pulmonar, avaliamos outro pilar importante da asma, a participação humoral. No nosso estudo, a dosagem de imunoglobulinas OVA-específicas no plasma dos animais sensibilizados demonstrou aumento significativo nos níveis de IgG1 e IgE (imunoglobulinas anafiláticas, reguladas por Th2), além da imunoglobulina IgG2a (reguladas por Th1) (Guo et al., 2015) em animais sensibilizados e o treinamento físico não alterou essa elevada produção. Esse mesmo fenômeno já foi detectado por alguns autores (Vieira, et al, 2008; Olivo, et al, 2014; Silva, et al, 2009), sugerindo que os efeitos do exercício físico não agem sobre os plasmócitos ou células B, produtores destas imunoglobulinas (Lambrecht, Hammad, 2015). 
A fim de avaliar o perfil celular presente na inflamação pulmonar alérgica crônica, buscamos quantificar e caracterizar as principais células envolvidas nesse processo inflamatório. Observamos que os animais sensibilizados à ovalbumina apresentaram elevação do número de eosinófilos presentes no tecido pulmonar como esperado, enquanto que os animais sensibilizados e treinados não obtiveram essa mesma elevação, indicando que o exercício reduz esse influxo. A redução da eosinofilia pulmonar pelo exercício físico já foi demonstrada por alguns autores, os quais indicaram que havia redução do número de eosinófilos no lavado broncoalveolar e no tecido pulmonar de animais asmáticos que foram submetidos a um protocolo de treinamento (Vieira, et al, 2007; Vieira, et al, 2008).

Animais sensibilizados ao antígeno ovalbumina apresentaram níveis elevados da citocina IL-4 e IL-6 e interessantemente o exercício físico moderado apresentou a capacidade de reduzir os níveis dessas citocinas no tecido pulmonar. Diversos estudos demonstram que essas citocinas de padrão Th2 estão aumentadas no tecido pulmonar em modelos de inflamação pulmonar alérgica crônica, sendo que, a citocina IL-4 mostrou-se importante no estabelecimento e manutenção da resposta Th2 (Lambrecht, Hammad, 2015). Além disso, alguns trabalhos demonstraram que animais sensibilizados à ovalbumina apresentaram aumento significativos dos níveis dessas citocinas e havendo redução dos níveis quando o animal é submetido ao protocolo de treinamento, o que corrobora com nossos dados (Silva, et al, 2010; Vieira, et al, 2008; Olivo, et al, 2014; Silva, et al, 2009; Vieira, et al, 2012; Mackenzie et al., 2016). 
O exercício físico agudo promove respostas anti-inflamatórias em modelo de inflamação leve, onde após a prática do exercício físico obtem-se aumento das citocinas anti-inflamatórias IL-10 e IL1-ra. A citocina IL-6 é encontrada em grande quantidade na circulação durante o exercício, esta está relacionada com a contração da musculatura esquelética e a infusão dessa citocina mimetiza totalmente os efeitos anti-inflamatórios do exercício, ambos dizem respeito a indução de IL-1ra e IL-10. Durante o exercício também há aumento de adrenalina, cortisol, hormônio do crescimento, prolactina e outros fatores que apresentam efeitos imunomoduladores (Walsh, et al, 2011).

A citocina IL-10 mostrou-se aumentada no grupo sensibilizado a ovalbumina e como esperado apresentou-se mais elevada nos grupos submetidos ao protocolo de treinamento. Alguns estudos já observaram este mesmo fenômeno anti-inflamatório do exercício físico, reduzindo níveis de citocinas IL-4, IL-5 e aumentando os níveis de citocinas IL-10 nos pulmões dos animais submetidos a protocolo de treinamento leve e moderado (Mackenzie et al., 2016; Olivo et al., 2012; Silva, Vieira, Perini, Mauad, \& Martins, 2010; Vieira et al, 2012).

Houve também o aumento dos níveis de TGF- $\beta$ (fator de crescimento transformante), nos grupos submetidos a treinamento físico, indicando que há mais uma citocina reguladora co-participando do processo anti-inflamatório do exercício físico. A citocina TGF- $\beta$ é conhecida como uma reguladora das respostas imunes, podendo regular a ativação, proliferação e diferenciação de células do sistema imune. O TGF- $\beta$ funciona como um indutor para a geração de Treg (Wan, et al. 2007). Converte células CD25- T virgens em células T reguladoras CD25+, e adicionalmente regulam a função supressora das Treg 
(Andersson J, et al. 2008; Shevach EM, et al. 2008). Antígenos podem induzir a Treg produtora de TGF- $\beta$ (Th3), que por sua vez media a imunossupressão (Chen, Kuchroo, Inobe, Hafler, Weiner, 1994).

TGF- $\beta$ também é um mediador participante do remodelamento na asma, sendo secretado não somente por diversas células do sistema imune mas também por fibloblastos, células endoteliais e vasculares (Kelley J, et al. 1991; Coker RK, et al. 1996; de Boer WI, 1998; Lee KY, 2006). Essa citocina tem um papel fundamental na produção e secreção de MMP-9 (metaloproteinase 9), enzimas estas que tem papel central no remodelamento de vias aéreas. (Crosby LM,et al. 2010). Porém o remodelamento de vias aéreas com aumento de fibras colágenas e elásticas não foi observado no nosso estudo.

Quando obervamos a quantificação das células T reguladoras ou Treg $\left(\mathrm{CD} 4{ }^{+} \mathrm{CD}^{2} 5^{+} \mathrm{FOXP}^{+}\right)$no tecido pulmonar, verificamos um aumento desse tipo celular nos grupos OEX quando comparado aos demais grupos, além disso, esse mesmo grupo experimental apresenta aumento de expressão de IL-10 o que vai de encontro com nossos dados na dosagem de citocinas no homogenato pulmonar. Vieira (2007), observou através do método de imunohistoquímica em animais sensibilizados e submetidos ao protocolo de treinamento um aumento significativo dos níveis de IL-10, assim como Silva (2009) - corroborando com os nossos achados (Silva, et al, 2010; Vieira, et al, 2007). Porém o estudo de Silva (2009), não observou aumento de expressão de FOXP3 em animais dos grupos sensibilizados e treinados (Silva, et al, 2009).

Além do aumento da expressão de IL-10 em T regs, observamos aumento da expressão de LAP (peptídeo relacionado a latência) nestas células, 
indo também de encontro com os nossos dados de dosagem de citocinas no homogenato pulmonar. LAP se torna um marcador importante de excreção de TGF- $\beta$ em T regs, pois o TGF- $\beta$ é sintetizado como proteína precursora que é modificada intracelularmente antes da secreção. Uma das modificações intracelulares mais relevantes é a clivagem da pró-região C-terminal da porção $\mathrm{N}$-terminal da proteína. A pró-região C-terminal é referida como o LAP enquanto a região N-terminal é chamada TGF- $\beta$ maduro ou TGF- $\beta$ ativo. Quando o TGF$\beta$ maduro está associado ao LAP, ele é chamado de L-TGF- $\beta$ e não pode interagir com seu receptor e não tem efeito biológico. Para o TGF- $\beta$ se tornar biologicamente ativo, o LAP tem que ser liberado de suas associações com o LTGF- $\beta$ ou sofrer alteração conformacional de tal forma que o LAP não seja liberado do complexo L-TGF- $\beta$, mas exponha o receptor de TGF- $\beta$ do sítio de ligação (Kalii, 1999).

As células T reg utilizam mediadores no controle de outros subtipos de células T (células de periferia), liberando IL-10 e TGF- $\beta 1$. No pulmão, acreditase que essas células apresentam papel primordial na proteção contra sequelas de processos inflamatórios de infecções de vias aéreas. Há evidências de que as células $T$ reg apresentam mediadores que induzem um tipo de tolerância a alérgenos inalados (protegendo a esse tipo de sensibilização) (Holt, et al, 2008). Estas células mostram-se eficientes na regulação de reações alérgicas, induzindo e mantendo a tolerância a alérgenos, diretamente inibindo a ativação de células Th2 (suprimindo a produção de IL-4, IL-5, IL-9 e IL-13), bloqueando a migração da célula Th2 efetora dentro do tecido inflamado, suprimindo a produção de lgE em células B e limitando a inflamação mediada por Th17. Em pacientes alérgicos foi demonstrado que o número de células $T$ reguladoras 
estão diminuídas e sua função prejudicada, uma das hipóteses sobre a patogênese da asma considera o papel da deficiência nas células T reguladoras (Stelmaszczyk-Emmel, 2014).

Segundo o estudo de Olivo (2012), cobaias que foram sensibilizadas apresentaram aumento do número de linfócitos no tecido pulmonar e quando submetidas ao protocolo de treinamento aeróbico apresentaram diminuição dessa elevação, o que vai de encontro com o estudo de Silva (2012), onde foi observada a elevação no número de linfócitos no lavado broncoalveolar de camundongos e quando submetidos ao protocolo de treinamento, observou-se a diminuição do número dessas células, marcadas por imunuhistoquímica apenas como células CD4+ presentes no tecido pulmonar (Olivo, et al, 2012; Silva, et al, 2012). No nosso trabalho, quando quantificamos as células TCD4+ presentes no tecido pulmonar, verificamos que houve aumento significativo do número dessas células nos grupos OEX quando comparados aos demais grupos experimentais e somente uma tendência na elevação do número de linfócitos $\mathrm{TCD}^{+}$no grupo OVA, que não foi estatisticamente significativa. Além disso, as células do grupo OEX apresentaram-se mais ativadas (aumento de expressão de CD69). Além das células TCD4+, foram também encontradas células TCD8+ em quantidade significativa no tecido pulmonar, com maior ativação celular (expressão de CD69) nos grupos sensibilizados e treinados.

Analisamos também o tecido linfóide e verificamos que os linfócitos TCD4 $^{+}$estão aumentados nos linfonodos mediastinais dos grupos sensibilizados. Além disso, verificamos que nos linfonodos dos animais que foram somente treinados (grupo EX) houve aumento de ativação (expressão de CD69) dos linfócitos TCD4+. Alguns estudos demonstraram que o exercício 
físico induz mudanças em subtipos de células mononucleares no sangue e justamente as concentrações de linfócitos TCD4+ e TCD8+ aumentam. (Pedersen, Hoffman-Goetz, 2000).

Em contrapartida, não observamos alterações significantes na expressão de LAP, IL-10 e CD69 dessas células, além de não encontrarmos diferenças relevantes no número de células TCD4 ${ }^{+} \mathrm{CD}_{2} 5^{+} \mathrm{FOXP}^{+}$nos linfonodos desses animais, o mesmo ocorreu na quantificação de células TCD8+. Os dados de quantificação e caracterização de linfócitos $T$ presentes no pulmão (sítio inflamatório) e linfonodos, permitem afirmar que o aumento de células regulatórias, expressão e excreção de citocinas reguladoras ocorre localmente no pulmão.

Existem células $\quad$ TCD8+ com capacidades imunoreguladoras/imunosupressoras em TCD4+ associadas a doenças inflamatórias como a asma. (G. Filaci, et al. 2011; K. Tsuchiya et al. 2009). Diversos mecanismos para a imunoregulação dessas células TCD8+ sob TCD4+ tem sido exploradas, como a liberação de citocinas reguladoras, contato célulacélula e lise citotóxica de APCs (células apresentadoras de antígeno) dependente de perfonina ou pelo modo fas-dependente. (S. Laffont et al. 2006; D. Kagi, et al. 1994). Indicando que as células TCD8+ podem apresentar função reguladora através de diversos mecanismos. A ativação de TCD8+ regula negativamente a proliferação de TCD4+ através da alteração de fenótipos e funções de células dendríticas. As células TCD8+ ativadas podem gerar um microambiente regulador, através de moléculas de adesão e liberação de citocinas, indicando um potencial de induzir regulação em DCs e enfim, ativando 
e proliferando células TCD4+. As DCs apresentam papel central na ativação e proliferação de TCD4, esse mesmo estudo mostrou que células TCD8+ apresentam capacidade de regular negativamente os fenótipos de células dendríticas esplênicas, como a expressão de CD86 e CD80 e MHC II, além disso, este estudo sugere que fatores solúveis liberados por células TCD8+ modifcam células dendríticas maduras em células dendríticas tolerogênicas. (F. Blengio, et al. 2013; Svensson, Maroof, Ato, Kaye, 2004) Já tem sido mostrado que as funções tolerogênicas de DCs estão intimamente relacionadas com citocinas imunossupressoras com TGF- $\beta$, IL-10. (Chen, et al. 2015; Morelli, et al. 2007).

Devido ao papel essencial das células dendríticas no mecanismo imunológico da doença, optamos por analisar diversos subtipos dessa célula nas amostras de pulmão e linfonodo dos animais dos grupos experimentais. No tecido pulmonar, foi possível observar que animais sensibilizados a ovalbumina apresentaram um aumento significativo de células dendríticas convencionais (cDCs), e o exercício físico reverte esse aumento. Essas células (cDCs) são abundantes nos órgãos linfóides (exceto o timo) e pode também ser encontrada em tecidos não-linfóides. Em modelos animais essa célula apresenta um papel crucial de iniciar e manter a respostas imunes (Plantinga et al., 2013).

Células dendríticas plasmocitóides ( $\mathrm{pDCs}$ ) no tecido pulmonar mostraram-se aumentadas no grupo que foi somente treinado, e também no grupo sensibilizado. Indicando que o exercício por si só pode promover imunorregulação, o que vai de encontro com nossos dados de IL-10, onde no grupo sensibilizado e treinado houve aumento desta mesma citocina. As células 
dendríticas plasmocitóides são bem conhecidas pelo seu papel regulador na asma e capacidade de liberar também IL-10 (Hammad, Lambrecht, 2008).

Já nos linfonodos dos animais, observamos tendência de aumento no número total de cDCs no grupo sensibilizado e treinado, além de diminuição da expressão de CD80, CD86 e ICOSL, quando comparado ao grupo somente sensibilizado. Também nos linfonodos, observamos o aumento de pDCs em animais sensibilizados a ovalbumina, aumento da expressão de ICOSL e diminuição de CD80 em animais sensibilizados e treinados. O aumento da citocina IL-10 - apresentada nas amostras dos animais sensibilizados e treinados - pode estar ligado com a diminuição da expressão das moléculas coestimuladoras CD80 e CD86. Estudos mostram que a citocina IL-10 apresenta capacidade de diminuir a expressão destas moléculas co-estimuladoras e até mesmo da expressão de MHC II, o que reduziria o perfil inflamatório das células dendríticas (Schülke, 2018).

Também nos linfonodos, observamos o aumento de pDCs em animais sensibilizados a ovalbumina, aumento da expressão de ICOSL e diminuição de CD80 em animais sensibilizados e treinados. A diminuição da expressão de moléculas co-estimulatórias CD80, CD86, bem como a diminuição da citocina pró-inflamatória IL-6 nos grupos sensibilizados e submetidos ao protocolo experimental estão diretamente ligadas ao aumento da citocina IL-10 nestes grupos. (Schülke, 2018) ICOSL é uma molécula co-estimuladora, pertencente da família B7 e apresenta similaridade com CD80 e CD86. Foi mostrado que o bloqueio de ICOSL há a exacerbação alérgica como o caso de encefalomielite em modelos experimental, sugerindo que a sinalização negativa regula 
respostas imunes não favoráveis.(Lee, et al, 2017). Estudos in vivo e in vitro mostraram claramente que pDCs podem estimular a indução de células T reg, possivelmente dependente de ICOSL. (Hammad, Lambrecht, 2008).

Sendo assim, a diminuição da expressão de moléculas co-estimuladoras como CD80, CD86 além do aumento da expressão de ICOSL em pDCs em animais do grupo OEX pode estar ligada a um mecanismo mais regulador destas células dendríticas.

Na quantificação de macrófagos, observamos que a sensibilização à ovalbumina foi capaz de aumentar o número de macrófagos totais, porém o exercício físico associado a sensibilização aumentou ainda mais o número de macrófagos no pulmão desses animais. Observando esse aumento do número de macrófagos, optamos por diferenciar esses macrófagos em M1 e M2. Verificamos que macrófagos M2 apresentaram-se elevados nos pulmões dos animais que foram sensibilizados e treinados, o mesmo fenômeno ocorre com os macrófagos M1 nos pulmões desses animais. Já quando analisamos a celularidade nos linfonodos mediastinais desses animais, observamos que os animais somente sensibilizados com ovalbumina apresentaram aumento do número de macrófagos $\mathrm{M} 2$, o que não ocorre com os animais sensibilizados e treinados, onde observamos redução do número desses macrófagos. Já na quantificação de macrófagos M1 não obtivemos diferenças importantes entre os grupos experimentais.

Macrófagos M1, conhecidos como macrófagos inflamatórios, são definidos por liberarem citocinas pró-inflamatórias, mediar a resistência aos 
agentes patogênicos e apresentam fortes propriedades microbicidas, mas estas também contribuem para a destruição de tecidos (Chavez-Galan, et al, 2015).

Os macrófagos M2, conhecidos como anti-inflamatórios, são células recrutadas em inflamações alérgicas (Chavez-Galan, et al, 2015). Essas células são induzidas por citocinas Th2 como IL-4, IL-13, IL-10, IL-33, TGF- $\beta$ e fagocitose de material apoptótico, sendo que a IL-4 tem sido mostrada como fator mais poderoso para diferenciação de macrófagos M2. Essas células produzem altos níveis de IL-10 e apresentam baixa capacidade de matar patógenos como bactérias e vírus e diminuir a magnitude e a duração da inflamação antagonizando as respostas mediadas por M1 e por células Th1, principalmente por um aumento da produção anti-inflamatória de citocinas IL-10 (Zdrenghea, et al, 2015). O aumento de macrófagos M2 presentes no tecido pulmonar está diretamente ligado com o aumento de citocinas IL-10 dosados no homogenato pulmonar de animais sensibilizados e submetidos ao protocolo de treinamento. Interessantemente, a redução do número de macrófagos M2 nos linfonodos dos animais sensibilizados e treinado (OEX) pode indicar interferência do exercício físico na migração dessas células.

Portanto, pode-se dizer que o aumento expressivo de células M2 no pulmão dos animais sensibilizados e submetidos ao protocolo de treinamento, assim como o aumento de células Treg podem estar ligados com o papel imunomodulador do exercício físico, explicando a diminuição da eosinofilia e produção de muco intraepitelial apresentada nesse grupo experimental. 

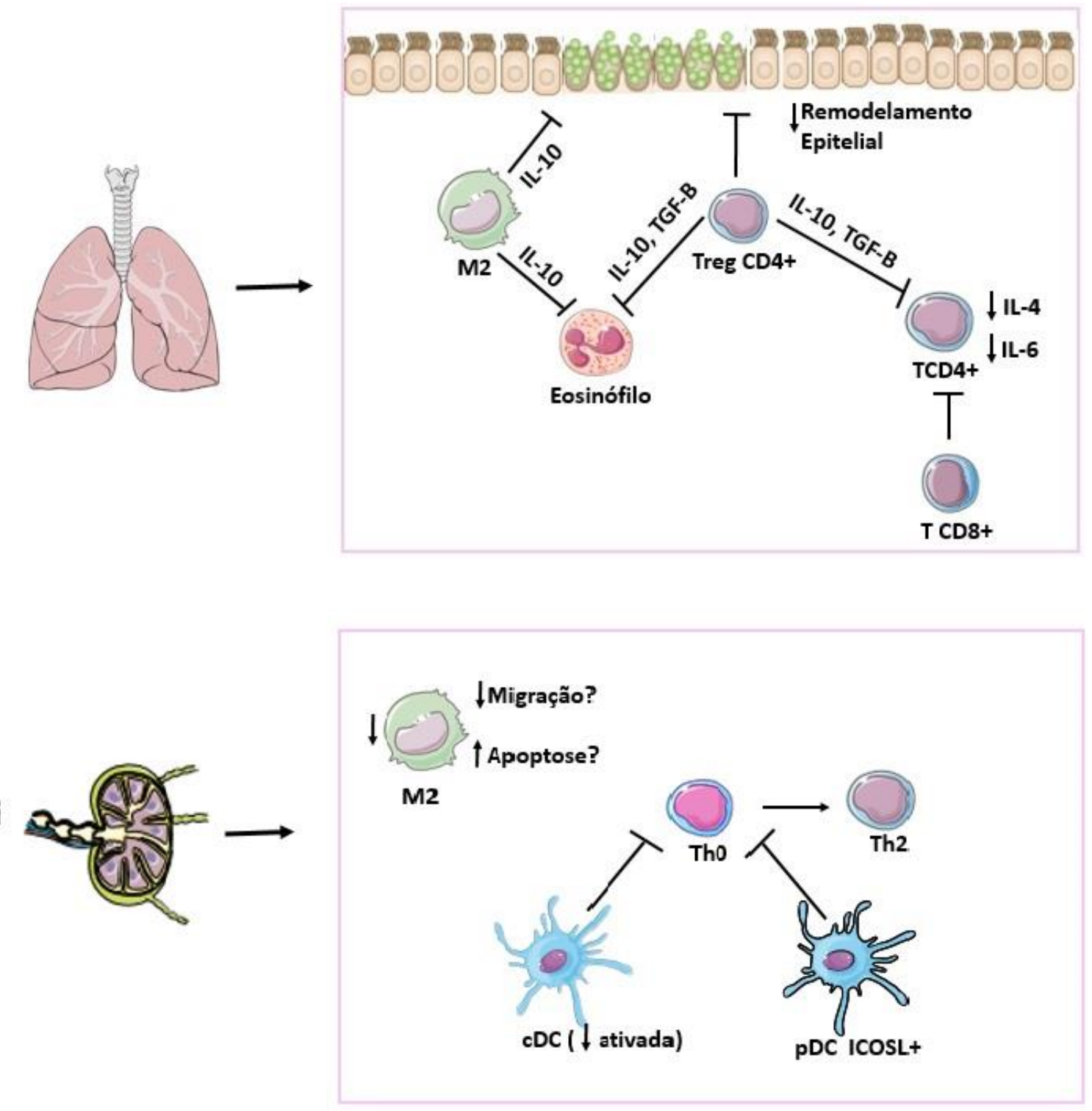

Figura 38 - Interação celular no pulmão e linfonodos de animais asmáticos e submetidos ao protocolo de treinamento. No pulmão, o aumento de células reguladoras Treg e M2, liberando citocinas como IL-10 e TGF- $\beta$ promovem redução do remodelamento epitelial, produção de muco, diminuição de eosinófilos, além de, juntamente com células TCD8+, regular negativamente células TCD4 diminuindo a produção de citocinas IL-4, IL-6. Já no linfonodo, há diminuição da quantidade de células $\mathrm{M} 2$, que pode ser por diminuição da migração celular ou até mesmo por apoptose. Além disso, a diminuição da ativação de CDCs e aumento de expressão de ICOSL+ em pDCs pode interferir na diferencição para uma resposta Th2, regulando assim a resposta inflamatória presente na asma. 


\section{CONCLUSÕES}

O exercício físico reduz a responsividade pulmonar, bem como o remodelamento epitelial e produção de muco induzido pelo antígeno ovalbumina. Além disso, o exercício físico modula a inflamação reduzindo o influxo eosinofílico pulmonar ao elevar células regulatórias como Treg e M2, produtoras de TGF- $\beta$ e IL-10, e esta última citocina apresentando a capacidade de interferir na atividade de células dendríticas diminuindo a expressão de moléculas co-estimuladoras e apresentando um papel mais regulador. 


\section{ANEXO}
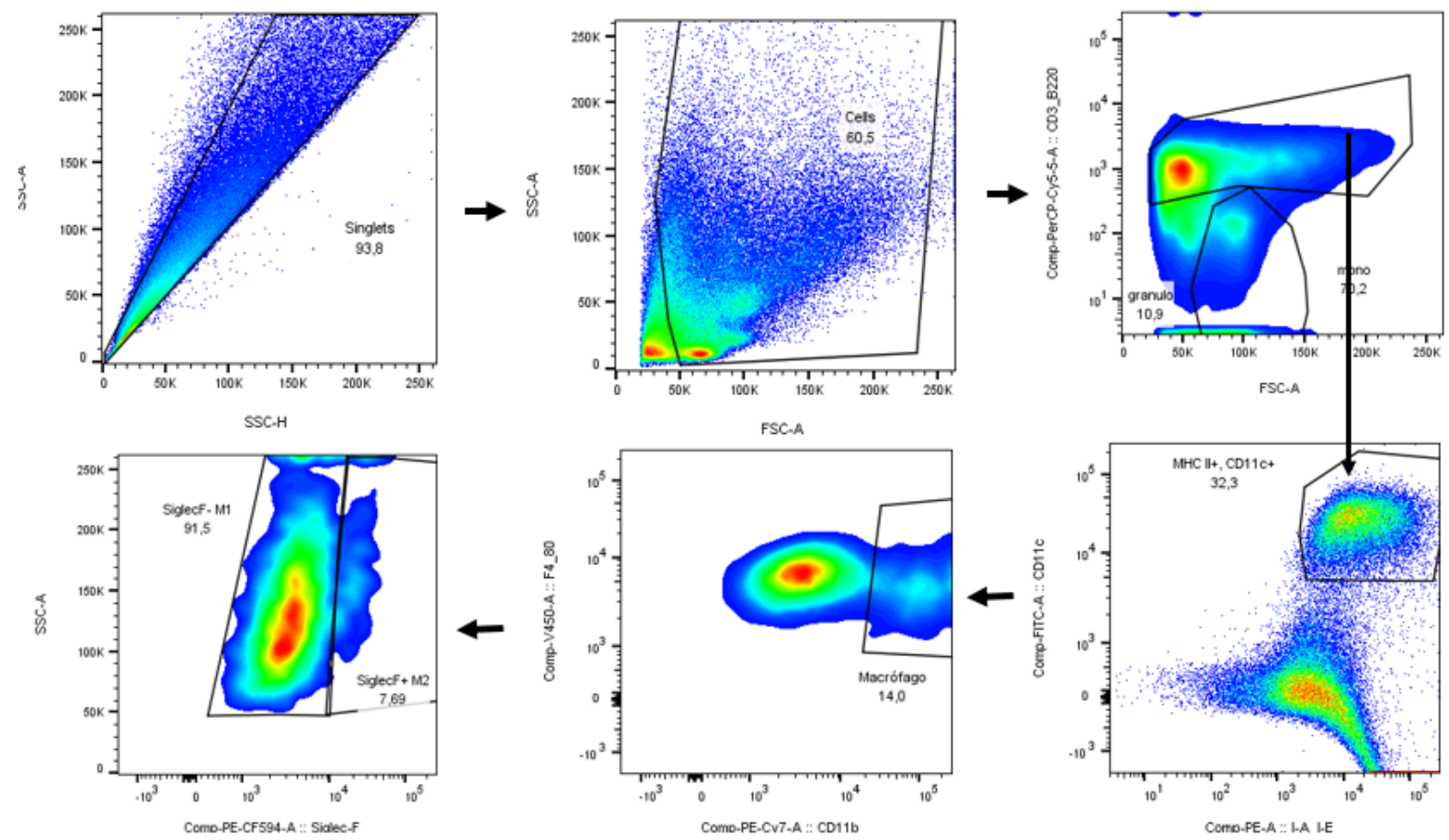

Figura 1 - Estratégia de Análise para caracterização de Macrófagos. 

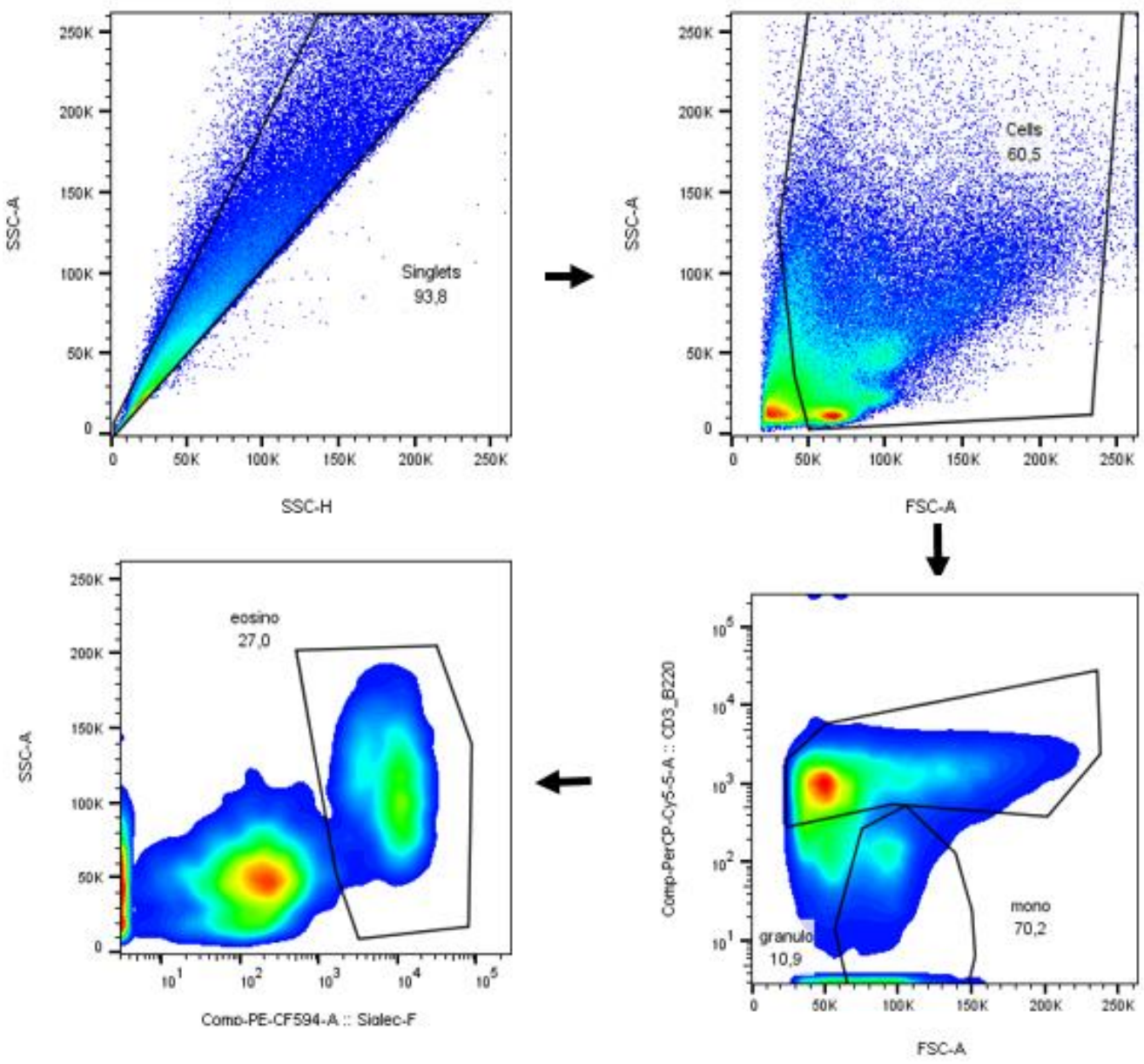

Figura 2 - Estratégia de Análise para caracterização de Eosinófilos. 

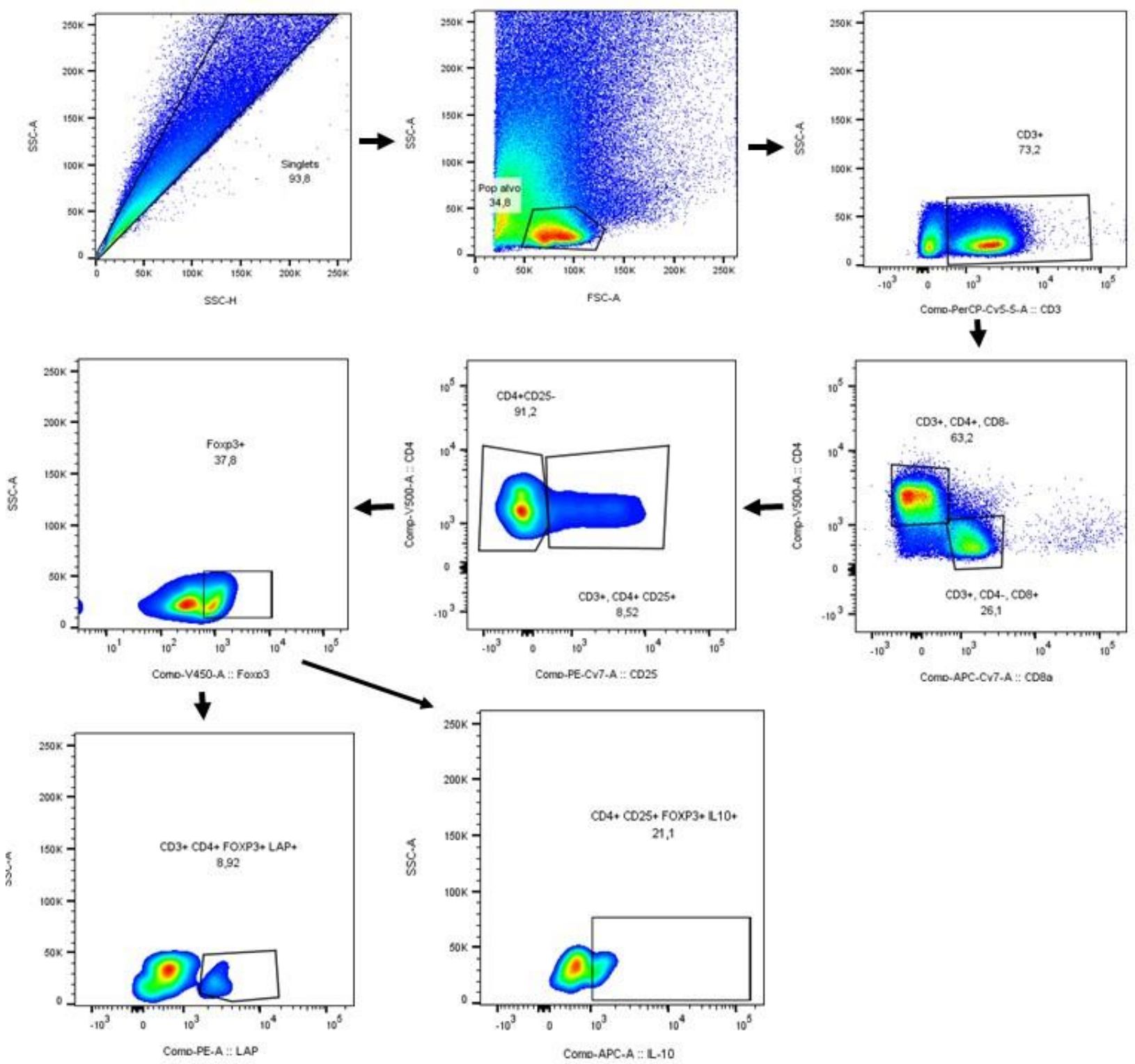

Figura 3 - Estratégia de Análise para caracterização de Linfócitos TCD4+. 

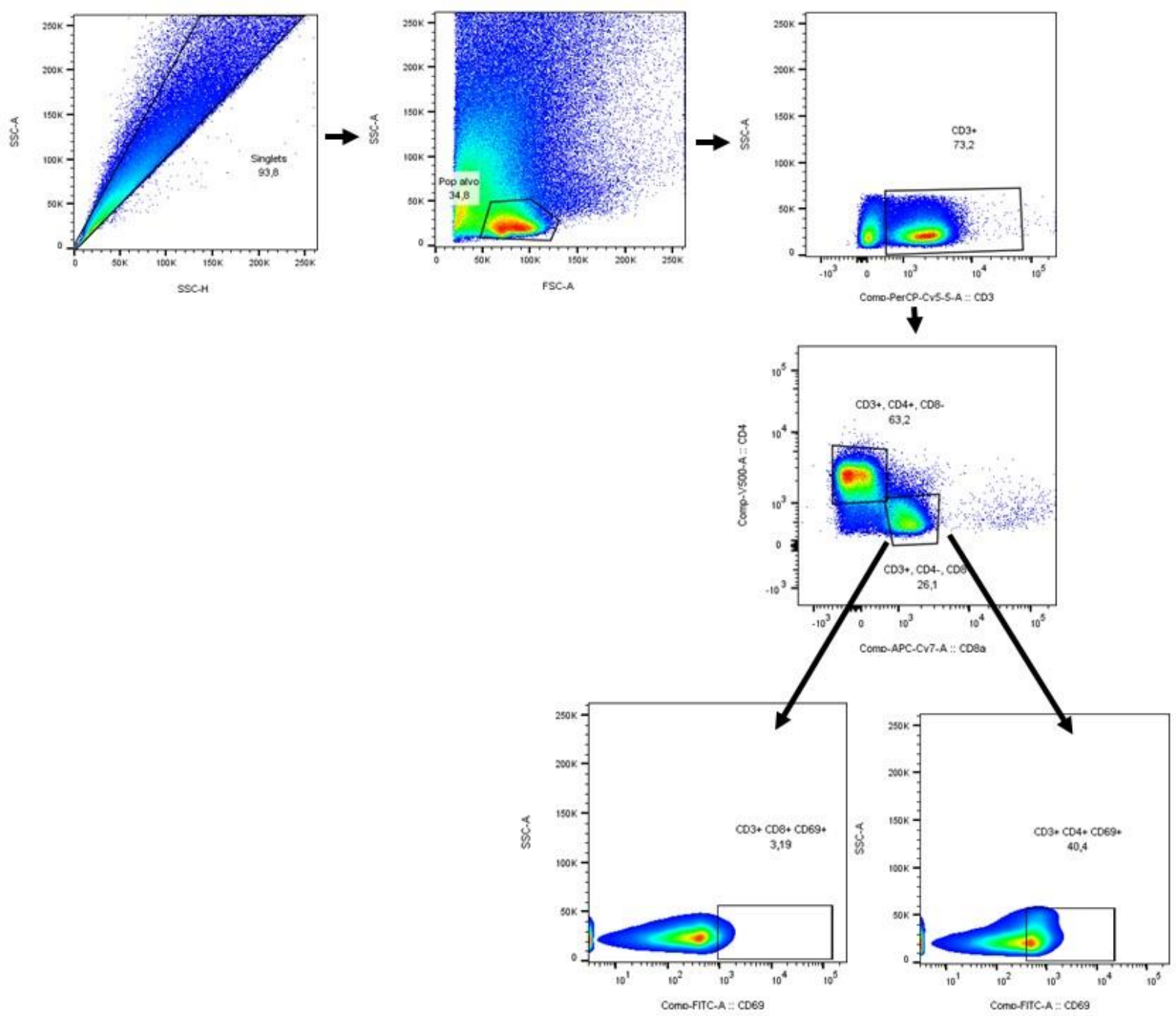

Figura 4 - Estratégia de Análise para caracterização de Linfócitos TCD8+ 

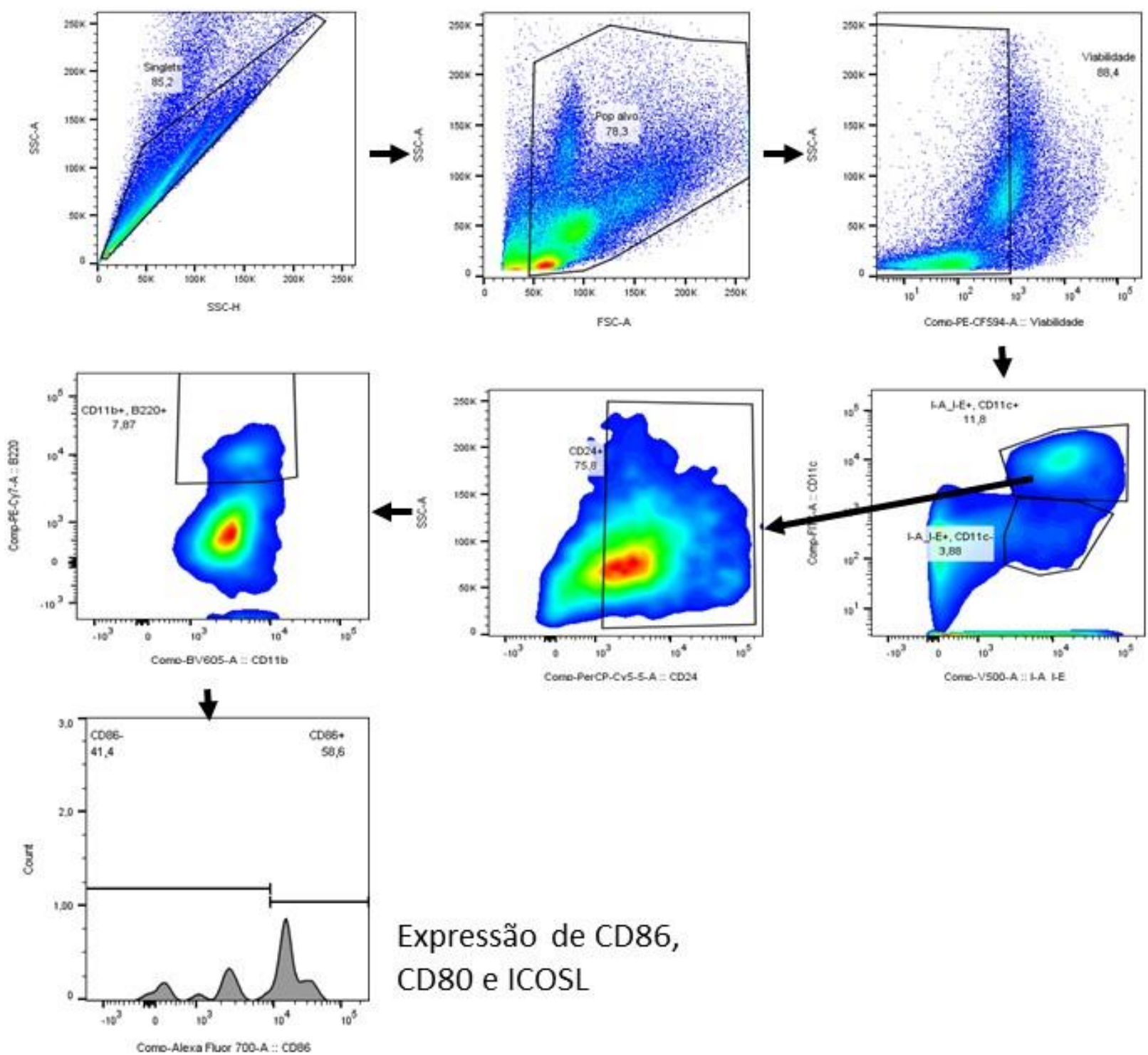

Expressão de CD86, CD80 e ICOSL

Figura 5- Estratégia de Análise para Caracterização de Células Dendríticas Convencionais. 

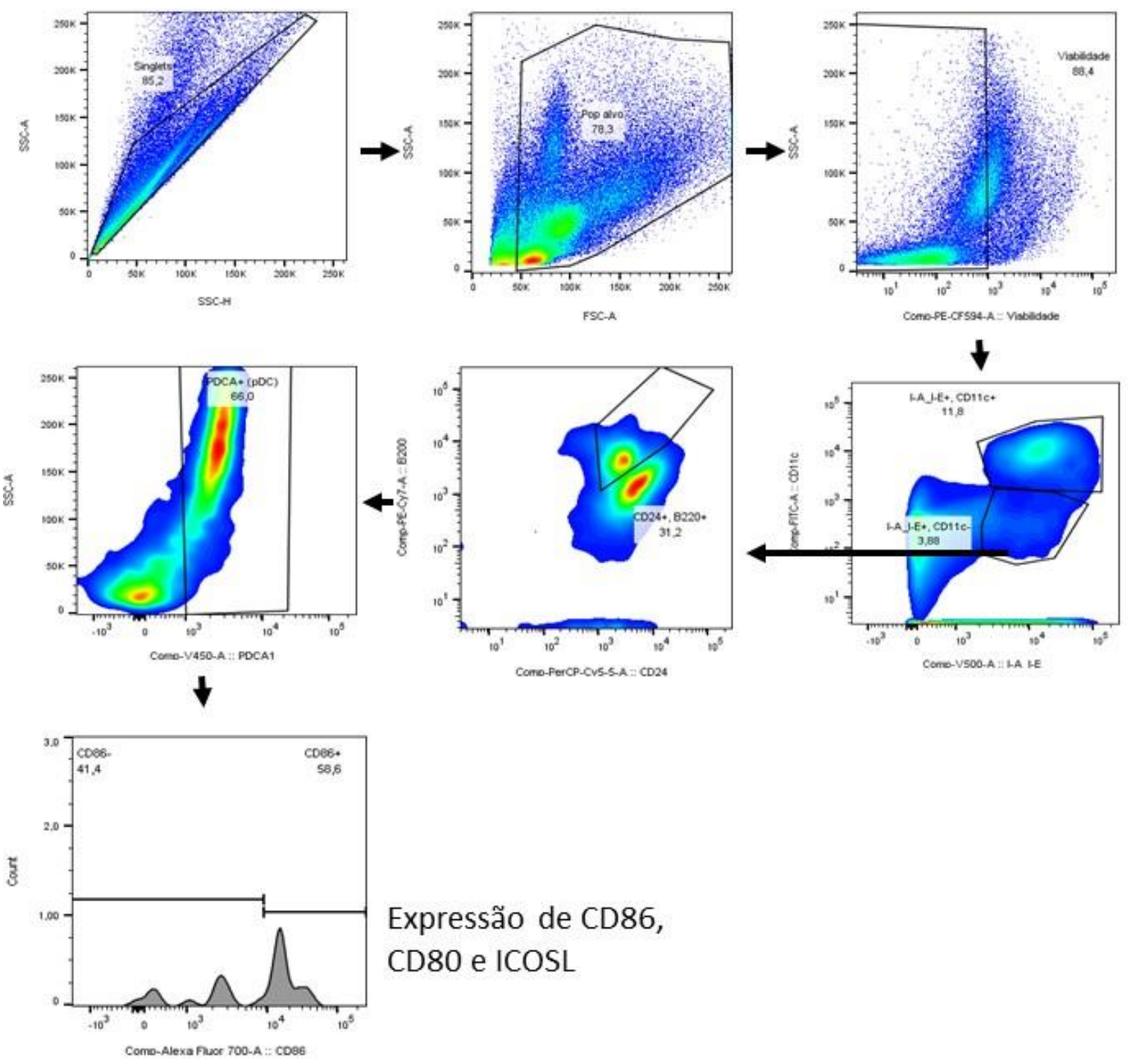

Figura 6 - Estratégia de Análise para Caracterização de Células Dendríticas Convencionais. 


\section{REFERÊNCIAS BIBLIOGRÁFICAS}

Abbas, Abul K., Imunologia celular e molecular. 8ª ed. Rio de Janeiro: Elsivier; 2015.

Abreu, S.C., et al., Bone Marrow, Adipose, and Lung Tissue-Derived Murine Mesenchymal Stromal Cells Release Different Mediators and Differentially Affect Airway and Lung Parenchyma in Experimental Asthma. Stem Cells Transl Med, 2017. 6(6): p. 1557-1567, 2014.

Adams, R. J., et al. Psychological factors and asthma quality of life: A population based study. Thorax, 59(11), 930-935.

Andersson J, et al. CD4+ Foxp3+ regulatory T cells confer infectious tolerance in a TGF-beta dependent manner. J EXP Med 2008 Set 1; 205 (9):1975-81.

Andrezza França-Pinto, et at. Aerobic training decreases bronchial hyperresponsiveness ans systemic inflammation in patients with moderate or severe asthma: a randomised controlled trial. 2015 Thorax.

Barrett, N.A. and K.F. Austen, Innate cells and T helper 2 cell immunity in airway inflammation. Immunity, 2009. 31(3): p. 425-37.

Chavez-Galan, L., et al., Much More than M1 and M2 Macrophages, There are also CD169 (+) and TCR (+) Macrophages. Front Immunol, 2015. 6: p. 263.

Chen, $W$, et al. Immunoregulation by members of the TGF $\beta$ superfamily. Nature Reviews. 2016, 723-739.

Chen, Don; et al. CD8+T activation attenuates CD4+T proliferation through Dendritic Cells modification. Cell Immunology 2015. 296, 138-148. 
Chen, Y., et al. Regulatory T cell clones induced by oral tolerance: suppression of autoimmune encephalomyelitis. Science, 265(5176), 1237-1240, 1994.

Clark, C. J., \& Cochrane, L. M. Assessment of work performance in asthma for determination of cardiorespiratory fitness and training capacity. Thorax, 43(10), 745-749, 1988.

Cluley, S., \& Cochrane, G. M. Psychological disorder in asthma is associated with poor control and poor adherence to inhaled steroids. Respiratory Medicine, 95(1), 37-39, 2001.

Coker RK, Laurent GJ, Shahzeidi S, Hernandez-Rodriguez NA, Pantelidis P, du Bois RM, et al. Diverse cellular TGF-beta 1 and TGF-beta 3 gene expression in normal human and murine lung. Eur Resp J 1996 Dez. 2501-7

Côté, A., Turmel, J., \& Boulet, L. P. Exercise and Asthma. Seminars in Respiratory and Critical Care Medicine, 39(1), 19-28, 2018.

Crosby LM, Waters CM. Epithelial repair mechanisms in the lung. Am J Physiol Lung Cell Mol Physiol Jun, 298 (6); 2010.

de Boer WI, et al. Transforming growth factor beta1 and recruitment of macrophages and mast cells in airways in chronic obstructive pulmonary disease. Am J Resir Crit Care Med Dec, 158(6): 1951-7, 1998.

D. Kagi et al, Fas and perforin pathways as major mechanisms of T cell-mediated cytotoxity, Science 265 (1994) 528-530.

Fox, D.A., N. Chiorazzi, and D.H. Katz, Hapten specific IgE antibody responses in mice. V. Differential resistance of IgE and IgG B lymphocytes to X-irradiation. J Immunol, 1976. 117(5 Pt 1): p. 1622-8. 
França-Pinto, A. et al. Aerobic training decreases bronchial hyperresponsiveness ans systemic inflammation in patients with moderate or severe asthma: a randomised controlled trial. (2015) Thorax.

G.Filaci, et al. CD8(+) Tregulatory/suppressor cells and their relationships with autoreactivity and autoimmunity, Autoimmunity 44 (2011), 51-57

GINA, G.I.f.A., Global Strategy for asthma management and prevention. 2014.

GINA, G.I.f.A. Global Strategy for asthma management and prevention. 2015.

Gour, N. and M. Wills-Karp, IL-4 and IL-13 signaling in allergic airway disease. Cytokine, 75(1): p. 68-78, 2015.

Guo, L., et al. Innate immunological function of $\mathrm{T} \mathrm{H} 2$ cells in vivo. Nature Immunology, 16(10), 1051-1059, 2015.

Hammad, H. and B.N. Lambrecht, Dendritic cells and epithelial cells: linking innate and adaptive immunity in asthma. Nat Rev Immunol, 8(3): p. 193-204, 2008.

Holt, P.G., et al., Regulation of immunological homeostasis in the respiratory tract. Nat Rev Immuno. 8(2): p. 142-52, 2008.

Ishizaka, K. and T. Adachi, Generation of specific helper cells and suppressor cells in vitro for the IgE and IgG antibody responses. J Immunol, 1976. 117(1): p. 40-7.

Jandl, K., et al., Activated prostaglandin D2 receptors on macrophages enhance neutrophil recruitment into the lung. J Allergy Clin Immunol, 2016; 137(3): p. 83343.

Kelly J, Kovacs EJ, Nichlson K, Fabisiak JP. Transforming growth factor beta production by lung macrophages ans fibroblasts. Chest Mar. 85s-6s, 1991 
Khalil, Nasreen. TGF- $\beta$ : from latent to active. Microbes and Infections, 1, 1999, $1255-1263$

Kim, Y.M., et al., Immunopathogenesis of allergic asthma: more than the th2 hypothesis. Allergy Asthma Immunol Res, 2013; 5(4): p. 189-96.

Kullowatz, A., Kanniess, F., Dahme, B., Magnussen, H., \& Ritz, T. Association of depression and anxiety with health care use and quality of life in asthma patients. Respiratory Medicine, 2007;101(3), 638-644.

K. Tsuchiya et al, Depletion of CD8+ $T$ cells enhances airway remodeling in a rodent model of asthma, Immunology. 2009; 126009 45-54

Kumar, R.K., et al., Interferon-gamma as a possible target in chronic asthma. Inflamm Allergy Drug Targets. 2006; 5(4): p. 253-6.

Lambrecht, B.N. and H. Hammad, The immunology of asthma. Nat Immunol. 2015; 16(1): p. 45-56,

Lee, Hyun-Joo, Kimm, Si-Na, Jeon, Myung-Shin Jeon, Yi, TacGhee, Song, SunU. ICOSL expression in human bone marrow-derived mesenchymal stem cells promotes induction of regulatory T cells. Scientific Reports. 2017; 1-15.

Lee KY, Ho HC, Lin HC, Lin SM, Liu CY, Huang CD, et al. Neutrophil -derived elastase induces TGF-beta1 secretion in human airway smooth muscle via NFkappaB pathway. Am J Respir Cell Mol Bol Out. 2006; 35(4): 407-14.

Mackenzie, B., et al., Dendritic Cells Are Involved in the Effects of Exercise in a Model of Asthma. Med Sci Sports Exerc. 2016; 48(8): p. 1459-67,

Morelli, A. E, A. W. Thomson, Tolerogenic dendritic cells and the quest for transplant tolerance, Nat Rev. Immunol. 2007; 610-621. 
Mota, Wong. Homologous and heterologous passive cutaneous anaphylactic activity of mouse antisera during the course of immunization. Life Science. 1969). $813-820$

Olivo, C.R., et al., Aerobic exercise attenuates pulmonary inflammation induced by Streptococcus pneumoniae. J Appl Physiol. 2014; 117(9): p. 998-1007.

Olivo, C.R., et al., Effects of aerobic exercise on chronic allergic airway inflammation and remodeling in guinea pigs. Respir Physiol Neurobiol. 2012; 182(2-3): p. 81-7.

Pedersen, B.K. and A.D. Toft, Effects of exercise on lymphocytes and cytokines. Br J Sports Med. 2000; 34(4): p. 246-51.

Pedersen, B.K. and L. Hoffman-Goetz, Exercise and the immune system: regulation, integration, and adaptation. Physiol Rev. 2000; 80(3): p. 1055-81.

Pedersin BK, Saltin B. Exercise as medicine-evidence for prescribing exercise as therapy in 26 different chronic diseases. Scand J Med Sci Sports. 2015.

Plantinga, M., et al. Conventional and Monocyte-Derived CD11b+Dendritic Cells Initiate and Maintain T Helper 2 Cell-Mediated Immunity to House Dust Mite Allergen. Immunity. 2013; 38(2), 322-335.

Read, K.A., et al., IL-2, IL-7, and IL-15: Multistage regulators of CD4(+) T helper cell differentiation. Exp Hematol. 2016; 44(9): p. 799-808.

Reddel, H.K., et al., A summary of the new GINA strategy: a roadmap to asthma control. Eur Respir J. 2015; 46(3): p. 622-39.

Reddel, K. H., \& Pedersen, S. GLOBAL STRATEGY FOR Global Strategy for Asthma Management and Prevention, 2018. 
Schülke, S. Induction of interleukin-10 producing dendritic cells as a tool to suppress allergen-specific T helper 2 responses. Frontiers in Immunology. 2018.

Shecach EM, Tran DQ, Davidson TS, Andersson J. The critical contribuition of TGF-beta to the induction of Foxp3 expression and regulatory T cell function. Eur J Immunol (4): 915-7, 2008

Shum, B.O., M.S. Rolph, and W.A. Sewell, Mechanisms in allergic airway inflammation - lessons from studies in the mouse. Expert Rev Mol Med, 2008. 10: p. e15.

Silva, A.C., et al., Exercise inhibits allergic lung inflammation. Int J Sports Med, 2012; 33(5): p. 402-9.

Silva, L.A., et al., Physical exercise increases mitochondrial function and reduces oxidative damage in skeletal muscle. Eur J Appl Physiol, 2009; 105(6): p. 861-7. Silva, R.A., et al., Aerobic training reverses airway inflammation and remodelling in an asthma murine model. Eur Respir J, 2010; 35(5): p. 994-1002.

Silva, R.A., et al., Airway remodeling is reversed by aerobic training in a murine model of chronic asthma. Scand J Med Sci Sports, 2014.

S. Laffont et al., CD8+ Tcell-mediated killing of donor dendritic cells prevents alloreactive T helper type-2 responses in vivo, Blood. 2006; 2257-2264.

Smith, B.J., E.G. Eakin, and A.E. Bauman, Physical activity is important, but can it be promoted in general practice? Med J Aust. 2003; 179(2): p. 70-1.

Stelmaszczyk-Emmel, A., Regulatory T cells in children with allergy and asthma: it is time to act. Respir Physiol Neurobiol. 2014; 209: p. 59-63.

Stephen T Holgate, Sally Wenzel, Dirkje S Postma, Scott T Weiss, Haral Renz, Peter D. Sly. Asthma. 2015; Nature Reviews. 
Svensson, M., Maroof, A., Ato, M., \& Kaye, P. M. Stromal cells direct local differentiation of regulatory dendritic cells. Immunity. 2004; 21(6), 805-816.

van Rijt, L.S. and B.N. Lambrecht, Dendritic cells in asthma: a function beyond sensitization. Clin Exp Allergy. 2005; 35(9): p. 1125-34.

Vieira, R.P., et al., Aerobic conditioning and allergic pulmonary inflammation in mice. II. Effects on lung vascular and parenchymal inflammation and remodeling. Am J Physiol Lung Cell Mol Physiol. 2008; 295(4): p. L670-9.

Vieira, R.P., et al., Aerobic exercise decreases chronic allergic lung inflammation and airway remodeling in mice. Am J Respir Crit Care Med, 2007. 176(9): p. 8717.

Vieira, R.P., et al., Anti-inflammatory effects of aerobic exercise in mice exposed to air pollution. Med Sci Sports Exerc, 2012. 44(7): p. 1227-34.

Vieira, R.P., et al., Creatine Supplementation Exacerbates Allergic Lung Inflammation and Airway Remodeling in Mice. Am J Respir Cell Mol Biol, 2007. Wan YY, Flavell RA. Regulatory $T$ cells, transforming frowth factor-beta and immune suppression. Proc Am Thorac Soc. 2007.

Walsh, N.P., et al., Position statement. Part one: Immune function and exercise. Exerc Immunol Rev, 2011. 17: p. 6-63.

Woods, J.A., Exercise and neuroendocrine modulation of macrophage function. Int J Sports Med, 2000. 21 Suppl 1: p. S24-30.

Woods, J.A., et al., Exercise training increases the naive to memory $T$ cell ratio in old mice. Brain Behav Immun, 2003. 17(5): p. 384-92.

Zdrenghea, M.T., et al., The role of macrophage IL-10/innate IFN interplay during virus-induced asthma. Rev Med Virol, 2015. 25(1): p. 33-49. 
Zieker, D., et al., CDNA-microarray analysis as a research tool for expression profiling in human peripheral blood following exercise. Exerc Immunol Rev, 2005. 11: p. 86-96. 